\title{
An Evaluation of West Virginia's Non-Industrial Private Forest Landowner Participation in Conservation Easements
}

Matt D. Oliver

West Virginia University

Follow this and additional works at: https://researchrepository.wvu.edu/etd

\section{Recommended Citation}

Oliver, Matt D., "An Evaluation of West Virginia's Non-Industrial Private Forest Landowner Participation in Conservation Easements" (2011). Graduate Theses, Dissertations, and Problem Reports. 3322.

https://researchrepository.wvu.edu/etd/3322

This Thesis is protected by copyright and/or related rights. It has been brought to you by the The Research Repository @ WVU with permission from the rights-holder(s). You are free to use this Thesis in any way that is permitted by the copyright and related rights legislation that applies to your use. For other uses you must obtain permission from the rights-holder(s) directly, unless additional rights are indicated by a Creative Commons license in the record and/ or on the work itself. This Thesis has been accepted for inclusion in WVU Graduate Theses, Dissertations, and Problem Reports collection by an authorized administrator of The Research Repository @ WVU. For more information, please contact researchrepository@mail.wvu.edu. 
An Evaluation of West Virginia's Non-Industrial Private Forest Landowner

Participation in Conservation Easements

\author{
Matt D. Oliver
}

Thesis submitted to the

Davis College of Agriculture, Natural Resources and Design

at West Virginia University

in partial fulfillment of the requirements

for the degree of

Master of Science

in

Forest Resources Management

Kathryn G. Arano, Ph.D., Chair

John R. Brooks, Ph.D.

David W. McGill, Ph.D.

David W. Saville, MS.

Division of Forestry and Natural Resources

Morgantown, West Virginia

2011

Keywords: West Virginia, NIPF, conservation easements, participation, woodland, development, logistic regression 


\section{ABSTRACT \\ An Evaluation of West Virginia's Non-Industrial Private Forest Landowner Participation in Conservation Easements}

\section{Matt D. Oliver}

Private forestland is an important resource to West Virginia. Timber production is vital to the state's economy and forestland is important for wildlife habitat, recreation and healthy watersheds. NonIndustrial Private Forest (NIPF) landowners control the majority of this commodity within the state and throughout the country. Development, fragmentation and parcelization are growing threats to landscape integrity and forest composition. Conservation easements are defined as contracts between private sector landowners and accredited institutions that preserve the conservation value of the land. They have become a popular land management tool in recent years. Conservation easements have also been widely accepted and utilized in the United States as well as around the world. Yet, conservation easement programs targeting West Virginia woodlands do not appear to be prospering. Therefore, an assessment of NIPF enrollment in conservation easement programs is a relevant endeavor. Surveys were developed to investigate what influences landowner decisions with regard to participation and were sent to both NIPF non-participants throughout West Virginia and to agencies and organizations interested in disbursing questionnaires to their conservation easement participants. Mail Survey data was collected in the fall of 2010 and spring of 2011. The primary goal of this study is to provide helpful information and possible recommendations that may improve participation in conservation easement programs and inform landowners.

The first examination is a forensic policy analysis of the Uniform Conservation Easement Act (UCEA) of 1981, which is the basis for the West Virginia Conservation and Preservation Act. This is an attempt to identify the fundamental causes that resulted in the legislative action. Secondary data from academic journals, books and professional sources were utilized to determine the root causes for the UCEA. The policy was then compared to three other alternatives (no policy change, privatizing and education) by three principles: 1) effectiveness; 2) administrative feasibility; and 3) ethics. Results showed the UCEA to be the most efficient policy instrument for protecting private land against development.

The second analysis examined NIPF landowners not participating in conservation easement programs. Summary statistics were utilized to compare the differences between NIPF landowners willing to consider enrolling their forest property in a forest easement program and those unwilling. Logistic regression was then employed to determine the factors influencing landowners' decision to participate in easement programs. The model showed several significant predictors from each category (property information, motivations and perceptions and demographics). Results indicate there are many factors affecting NIPF land management decisions (e.g., landowner concern with transferring property rights to future generations and/or their ability to pay the current property taxes, individual perception of government and non-governmental organizational trustworthiness and woodland location).

Recommendations include implementation of a regional marketing strategy, targeting specific landowners (e.g., larger amounts of acreage, majority forest cover and located in developmentally sensitive areas) and clear presentation of financial benefits to possible participants.

The third analysis evaluated conservation easement participants in West Virginia. Descriptive statistics were examined to gain insight into the attributes of landowners enrolled in easement programs. Results showed the most common primary use of eased land in the state to be farmland. While the primary motivation for easing the property was to prevent development. Most of the conservation easements were located in the developmentally sensitive eastern panhandle of West Virginia. 


\section{Dedication}

"Commit your works to the Lord, and your plans will succeed."

$\sim$ Proverbs 16:3

I would never have completed this work without a great deal of help and cooperation from other people. My parents, Reverend Dr. CD Oliver Jr. and Ruth Barber Oliver, have been an inspiration to me all my life, and my sister Sarah, who gladly provided me with assistance and encouragement. I am especially grateful to my grandmother, Virginia Barber, without her support this simply would not have happened. I am also grateful for the help, encouragement and inspiration given to me by many dear friends. Especially helpful were Jennifer Christian and Andrew Bodkin who regularly provided humor, advice and optimism to make finishing this report easier to accomplish. 


\section{Acknowledgement}

There were many people that contributed to this research. If not for them, completion of this thesis would not have been possible. I would like take a moment and acknowledge them for their time and efforts.

For starters, I would like to thank my advisor, Dr. Kathryn Arano. Thank you for having confidence in my abilities. I greatly appreciate the diligence, guidance and encouragement that you have provided during the last two years.

Next I would like to thank each committee member: Dr. John Brooks, Dr. Dave McGill and Dave Saville. Thank you for being ready and willing to help throughout this process. I genuinely appreciate the advice; encouragement and friendly conversation each of you have given.

I am also grateful for the assistance and knowledge provided by Joe Hatton. Thank you for spending countless hours guiding me through the practical application of this research. I really appreciate your willingness to help me bridge the gap between theory and actuality; and for your friendship.

I owe gratitude to the many contacts and organizations that forwarded questionnaires on to their conservation easement participating landowners. That data would not have been acquired if it were not for your collaborative efforts. Thank you for showing interest in this research and the invaluable assistance that followed.

Finally, I would like to thank the faculty, staff and my fellow graduate students in the Division of Forestry and Natural Resources at West Virginia University. You all have collectively provided me with both academic insights and fond memories. 


\section{Table of Contents}

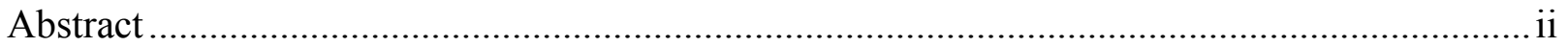

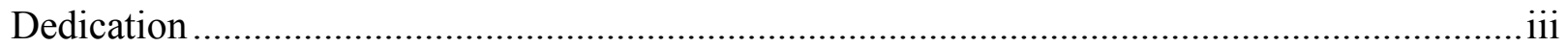

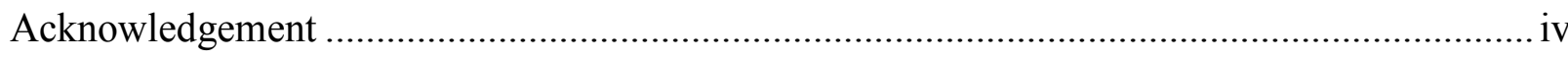

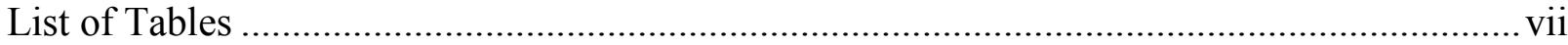

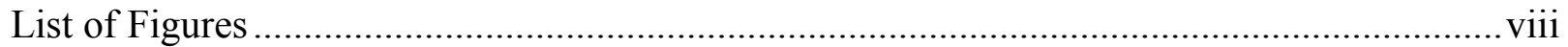

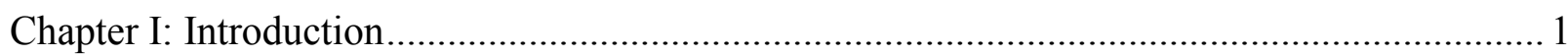

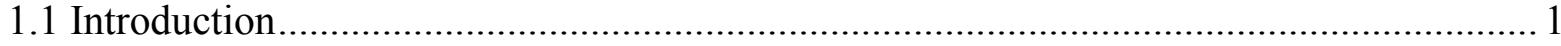

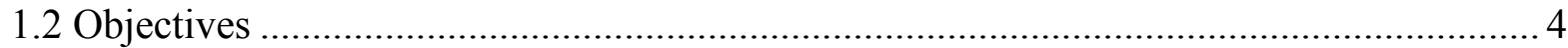

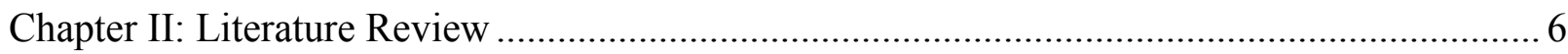

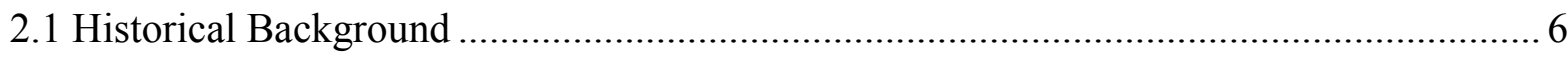

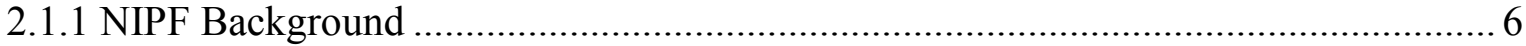

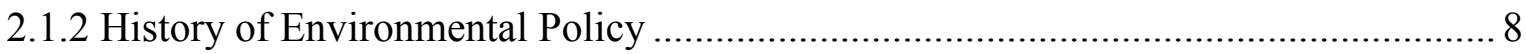

2.1.3 History of Conservation Easements ................................................................... 10

2.2 Structure of Conservation Easements ................................................................... 14

2.3 Financial Benefits and Conservation Easements .................................................... 15

2.4 Examination of Programs in West Virginia ............................................................... 17

2.5 Examination of Programs in Other States............................................................... 18

2.6 The Impact of Conservation Easements ................................................................... 20

Chapter III: The Uniform Conservation Easement Act: A Forensic Policy Analysis ............... 21

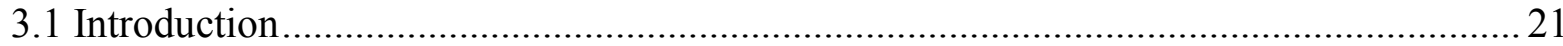

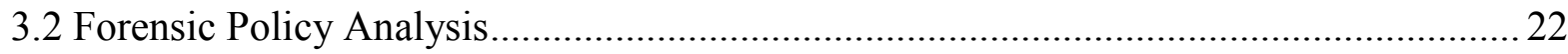

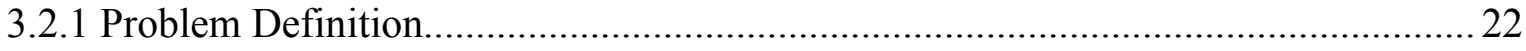

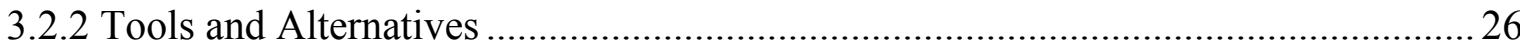

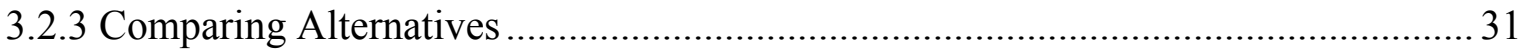

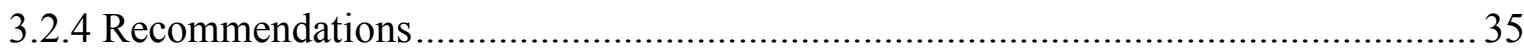

Chapter IV: Modeling Likelihood to Participate in Forestland Conservation Easement

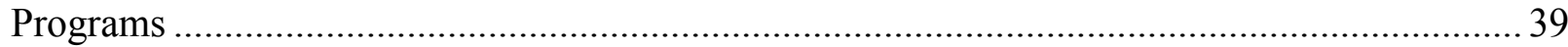

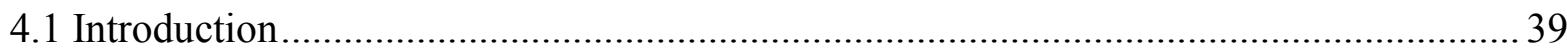

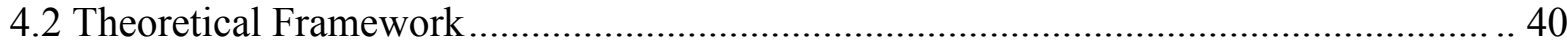

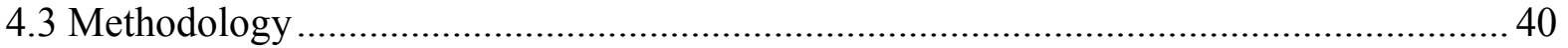




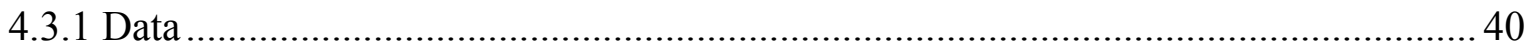

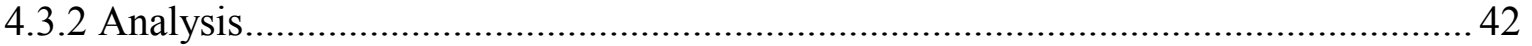

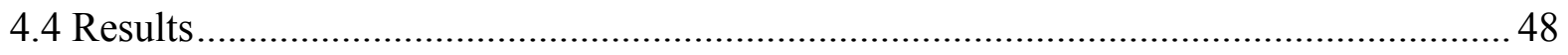

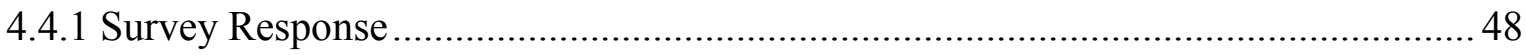

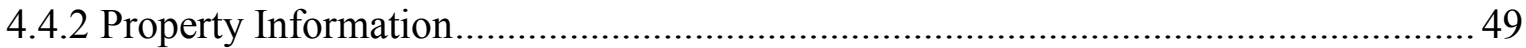

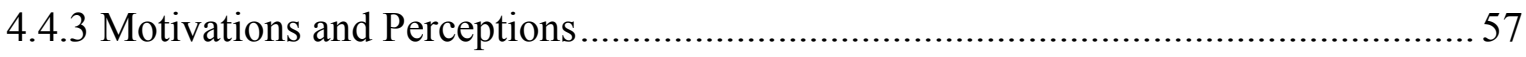

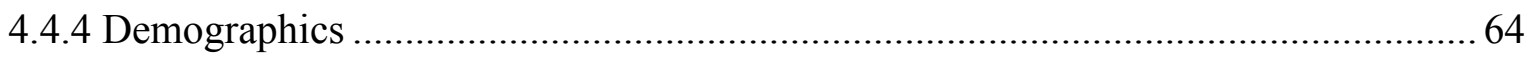

4.4.5 Factors Affecting Participation in a Forest Conservation Easement Program ..........68

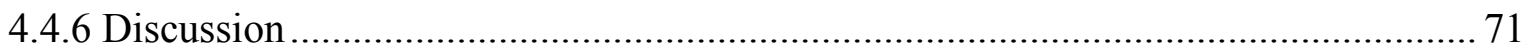

Chapter V: Attributes of Conservation Easement Participants................................................ 82

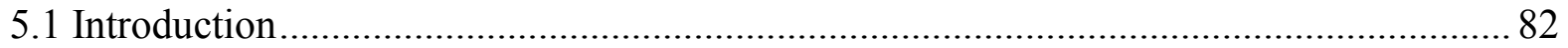

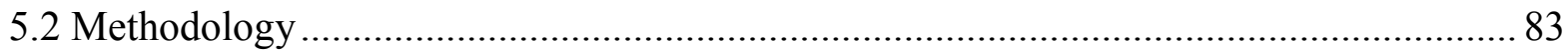

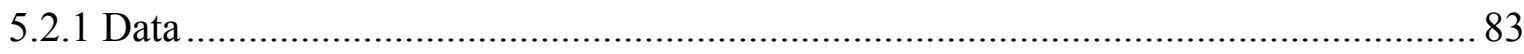

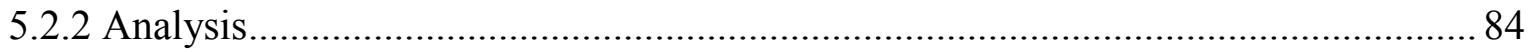

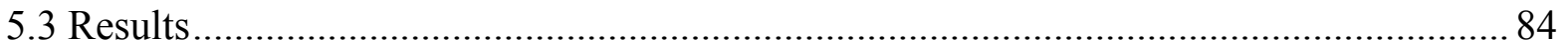

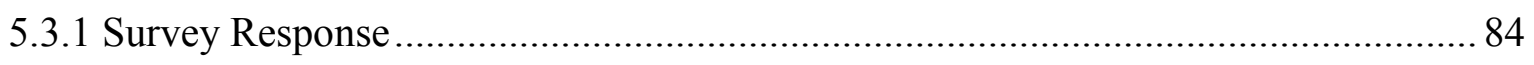

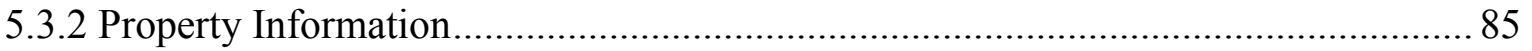

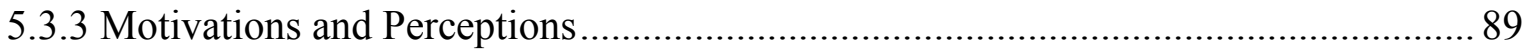

5.3.4 Conservation Easement Participants....................................................................... 95

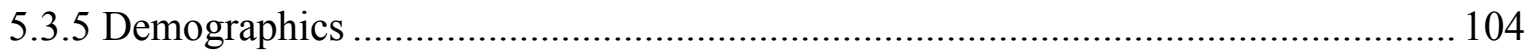

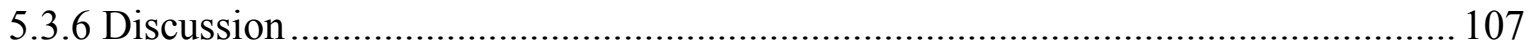

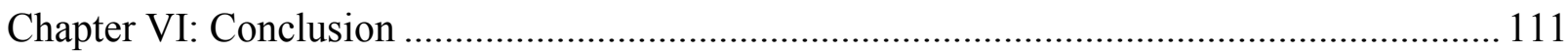

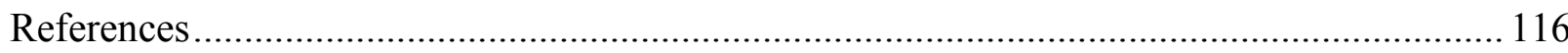

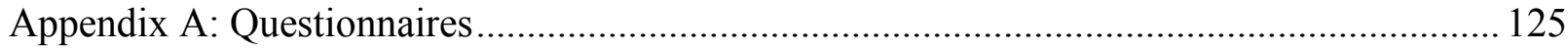

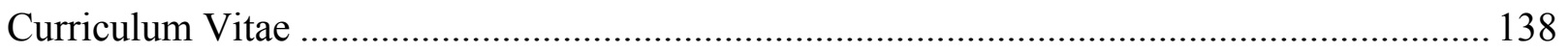




\section{List of Tables}

Table 3.1: Decision matrix for comparing UCEA policy alternatives 33

Table 4.1: Explanation of independent variables in the empirical model which evaluates what influences landowners to consider enrolling their property in a forest conservation easement program as reported by NIPF landowners in West Virginia, 2011 ............. 43

Table 4.2: Property statistics as reported by NIPF landowners in West Virginia, 2011 .............57

Table 4.3: Percentage of income derived from the land as reported by NIPF landowners in West Virginia, 2011

Table 4.4: Potential motivations for enrollment as reported by NIPF landowners in West Virginia, 2011

Table 4.5: Potential barriers for enrollment as reported by NIPF landowners in West Virginia,

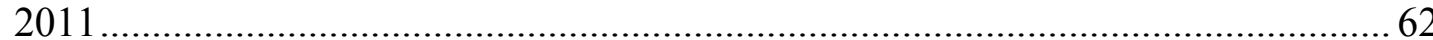

Table 4.6: Importance of conservation and preservation topics as reported by NIPF landowners in West Virginia, 2011. 63

Table 4.7: Perception of organizational trustworthiness as reported by NIPF landowners in

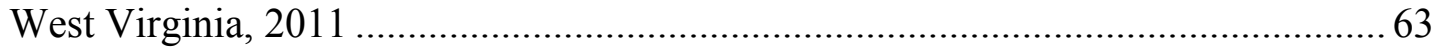

Table 4.8: Age and income as reported by NIPF landowners in West Virginia, 2011 ................65

Table 4.9: Logistic regression model evaluating West Virginia NIPF landowner participation

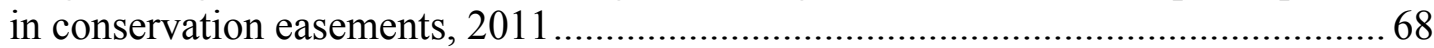

Table 5.1: Property statistics as reported by CE participants in West Virginia, 2011 ................. 89

Table 5.2: Percentage of income derived from the land as reported by CE participants in West

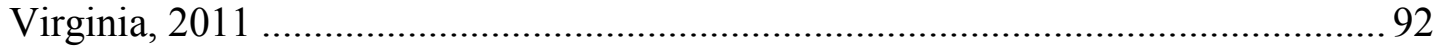

Table 5.3: Potential motivations for enrollment as reported by CE participants in West Virginia,

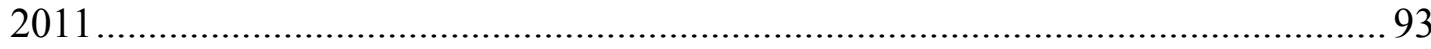

Table 5.4: Potential barriers for enrollment as reported by CE participants in West Virginia,

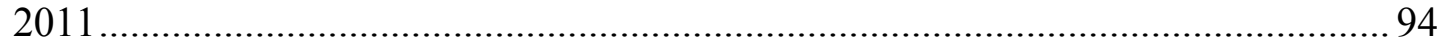

Table 5.5: Importance of conservation and preservation topics as reported by CE participants in

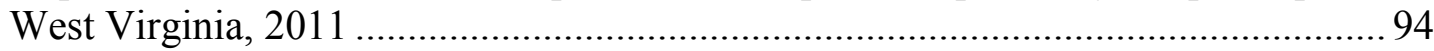

Table 5.6: Perception of organizational trustworthiness as reported by CE participants in West

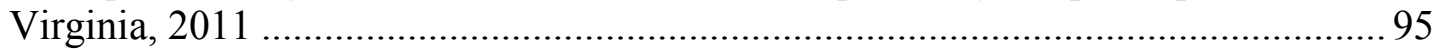

Table 5.7: Length of acquisition as reported by CE participants in West Virginia, 2011 ......... 101

Table 5.8: Important aspects of conservation easements as reported by CE participants in West

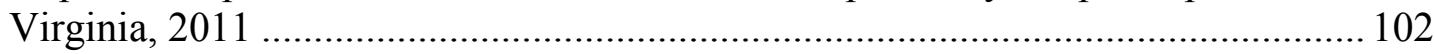

Table 5.9: Agreement level regarding restrictions as reported by CE participants in West

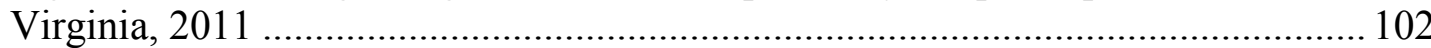

Table 5.10: Amount of landowner satisfaction with their decision as reported by CE

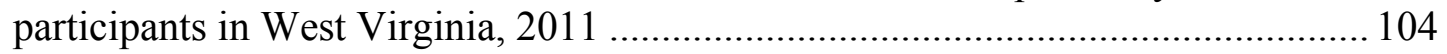

Table 5.11: Age and income as reported by CE participants in West Virginia, 2011 .............. 105 


\section{List of Figures}

Figure 4.1: Would you ever consider enrolling your property in a forest conservation easement program? As reported by NIPF landowners in West Virginia, 2011 ...................... 49

Figure 4.2: Resource Conservation and Development Areas. West Virginia, 2011 ................... 50

Figure 4.3: Location of woodland property as reported by NIPF landowners in West Virginia,

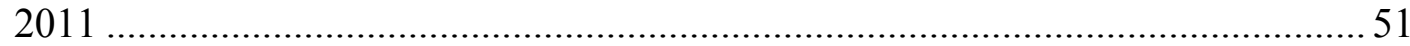

Figure 4.4: Primary use of land as reported by NIPF landowners in West Virginia, 2011 ........52

Figure 4.5: Generation of landowner as reported by NIPF landowners in West Virginia, 2011 53

Figure 4.6: Landowner concern about transferring property rights to future generations as reported by NIPF landowners in West Virginia, 2011 ...........................................5 54

Figure 4.7: Landowner concern with their ability to pay the current property taxes as reported by NIPF landowners in West Virginia, 2011..........................................................5

Figure 4.8: Whether the landowner was raised on or near the property they own as reported by NIPF landowners in West Virginia, 2011 .............................................................5 56

Figure 4.9: Landowner perception of the most valuable aspect of their property as reported by NIPF landowners in West Virginia, 2011...........................................................58

Figure 4.10: Type of environment respondents were raised within as reported by NIPF

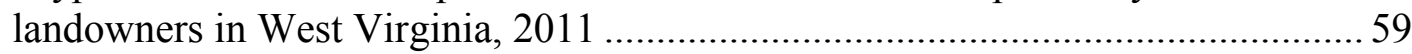

Figure 4.11: Current living environment as reported by NIPF landowners in West Virginia, 2011

Figure 4.12: Whether respondents consider their property to be a monetary investment as reported by NIPF landowners in West Virginia, 2011

Figure 4.13: Location of primary residence as reported by NIPF landowners in West Virginia, 2011

Figure 4.14: Level of education as reported by NIPF landowners in West Virginia, 2011.........66

Figure 4.15: Gender as reported by NIPF landowners in West Virginia, 2011 ...........................67 67

Figure 5.1: Primary use of land as reported by CE participants in West Virginia, 2011 ............86 86

Figure 5.2: Generation of landowner as reported by CE participants in West Virginia, 2011 ... 86

Figure 5.3: Landowner concern about transferring property rights to future generations as reported by CE participants in West Virginia, 2011 ................................................ 87

Figure 5.4: Landowner concern with their ability to pay the current property taxes as reported by CE participants in West Virginia, 2011 ............................................................... 88

Figure 5.5: Whether the landowner was raised on or near the property they own as reported by

CE participants in West Virginia, 2011 ............................................................... 88

Figure 5.6: Landowner perception of the most valuable aspect of their property as reported by CE participants in West Virginia, 2011 ............................................................... 90

Figure 5.7: Type of environment respondent was raised within as reported by CE participants

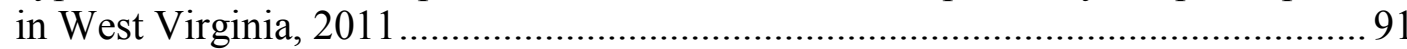

Figure 5.8: Current living environment as reported by CE participants in West Virginia,

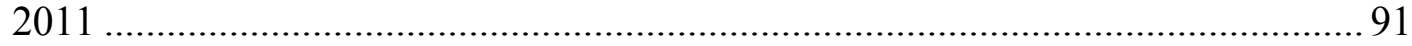

Figure 5.9: Whether respondents consider their property to be a monetary investment as reported by CE participants in West Virginia, 2011 ................................................ 92

Figure 5.10: Resource Conservation and Development Areas, West Virginia, 2011................. 96 
Figure 5.11: Location of conservation easement as reported by CE participants in West

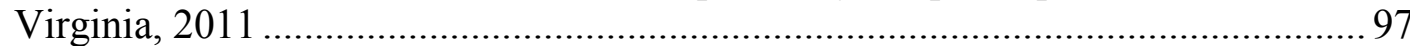

Figure 5.12: Whether or not the landowner placed the conservation easement on the property as reported by CE participants in West Virginia, 2011........................................... 98

Figure 5.13: Primary motivation for placing a conservation easement on the property as reported by CE participants in West Virginia, 2011 ........................................... 99

Figure 5.14: Method of exposure to conservation easements as reported by CE participants in West Virginia, 2011 ..................................................................................... 100

Figure 5.15: Method of payment chosen by the landowner as reported by CE participants in

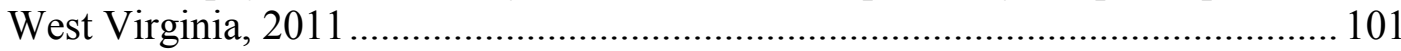

Figure 5.16: Conservation easement grantee as reported by CE participants in West Virginia, 2011 103

Figure 5.17: Easement classification as reported by CE participants in West Virginia, 2011 104

Figure 5.18: Region of primary residence as reported by CE participants in West Virginia, 2011 105

Figure 5.19: Level of education as reported by CE participants in West Virginia, 2011 _........ 106 Figure 5.20: Gender as reported by CE participants in West Virginia, 2011 106 


\title{
Chapter I: Introduction
}

"Conservation is the application of common sense to the common problems for the common good"

\author{
-Gifford Pinchot
}

\subsection{Introduction}

The United States of America has enormous natural resources, which provide tremendous opportunities for developing and implementing good stewardship practices. There are 751 million acres of forests in the nation (USDA Forest Service 2007). Federally protected public lands represent thirty-six percent of the acreage. Native Americans hold two percent and NonIndustrial Private Forest (NIPF) landowners' control sixty-two percent of forestland in the country (Cubbage et al. 1993). With regard to West Virginia, the state has abundant woodland that is vital to its economy. Much like the nation as a whole, NIPF landowners possess the majority of the resource in the third most heavily forested state in the nation. In fact, NIPF landowners hold 10,418,000 of West Virginia's 12,007,000 acres of timberland (USDA Forest Service 2010c).

NIPF landowner dominance of woodland resources has been a major contributor for conservation program initiatives such as conservation easements. "A conservation easement is a legal agreement between a landowner and an eligible organization that restricts future activities on the land to protect its conservation values" (Byers and Ponte 2005, p. 7). They have been a land management tool utilized by all 50 states and are common policy instruments chosen by land trust agencies (Byers and Ponte 2005). This strategy can be readily applied to the immense NIPF population and oblige their various objectives, all while protecting forestland.

Conservation easements are a valuable tool for protecting forestland, farmland, biodiversity and defending against urban sprawl in the state of West Virginia. There are 
numerous organizations that offer conservation easements in the state. The United States Department of Agriculture, Natural Resource Conservation Service (USDA NRCS), the West Virginia Division of Forestry (WVDOF) and many non-governmental organizations (NGOs) such as the West Virginia Chapter of The Nature Conservancy (WVTNC) are available grantees. Policies that allow for conservation easement programs in West Virginia include the U.S. Farm Bill and the Uniform Conservation Easement Act (USDA Forest Service 2010b; Johnson and Monke 2010; Anderson 1997).

NIPF landowners play an important role in sustaining timber resources and preserving forestlands nearby and nationwide. Therefore, defining what causes West Virginia's NIPF to place easements on their property is essential to increasing their participation in such programs and furthering conservation. Fragmentation and parcelization are common in private forests and heighten losses while damaging composition as well as future potential and ecological value (Best 2002). There are varying definitions of fragmentation and parcelization but here they are defined as follows. Fragmentation is characterized as small amounts of forestland owned for environmental or aesthetic value rather than timber production (Sampson and DeCoster 2000; Forest Research 2010). Closely related, parcelization is defined as the movement from few landowners with large tracts of forestland to several landowners with little acreage (Mehmood and Zhang 2001).

Good forestry practices are vital to West Virginia's landscape and economy especially since development pressure is constantly increasing in certain regions, such as the eastern panhandle. The eastern panhandle is situated close to crowded, urban centers (Baltimore, MD and Washington, DC) which make conservation paramount (Jennings et al. 2003). These areas have become suburbs to nearby metropolitan areas; threatening biodiversity and disturbing 
natural resources. The debate over sustainable development, conservation of natural resources and climate change has become well known to the general public. Issues extend from habitat degradation to minimal infrastructure for growing populations in little townships; which are now "bedroom communities" for neighboring cities (Blaine et al. 2003).

Easements are well suited to alleviate many of the development pressures caused by urbanization. In fact, the majority of contracts regulate development of the land (Kiesecker et al. 2007). Yet, it would be helpful to understand how landowners view the ecological and social advantages of their conservation involvement, which is usually not included in government documents (Wallace et al. 2008). Also, increased enrollment in forestry programs, such as conservation easement initiatives, requires a knowledge of individual differences as well as knowledge of landowner goals and values (Nagubadi et al. 1996). Therefore, evaluating participation in easement programs for NIPF landowners can provide insight regarding these influential factors. Development is increasing while land area is not. For this reason, it is imperative to understand and utilize policy tools, such as conservation easements, in order to sustain West Virginia's natural resources.

Two attractive aspects of conservation easements are tax incentives and the ability to achieve diverse goals of different landowners. These provisions, coupled with the common perpetuity aspect of easements, make the alternative distinct. The Forest Legacy Program has been a popular conservation easement initiative provided by the government but it has an even greater potential when accompanied by independent programs (Beliveau 1993). In addition, there are thousands of land trust organizations throughout the United States that provide easements, which makes them accessible to many private landowners. Land trusts are defined by the Land Trust Alliance (LTA) as "any organization that acts directly to conserve land" (Merelander et al. 
2004, p. 68; Fishburn et al. 2009). Furthermore, the LTA works to conserve land for the benefit of both communities and natural systems (Land Trust Alliance 2011). This is a concept which parallels sustainable development, which is an attempt to assimilate development and renewable resource conservation.

Though easements are a good tool for conservation among NIPF owners, there are criticisms. Management planning, records and inventories, and monitoring are either unsatisfactory or produce serious challenges (Mortimer et al. 2007). These shortcomings are likely due to limited funding and manpower. Moving forward, necessary monitoring standards for conservation easements should be integrated by land trusts (Kiesecker et al. 2007). A lack of information available to landowners has been shown to be an area of difficulty for conservation easement program participation. Understanding landowner motivations for placing an easement on their property may provide knowledge on how these shortcomings affect decisions by the private sector. Moreover, investigating NIPF participation in conservation easements offered by government and independent organizations may help in alleviating these problems.

\subsection{Objectives}

The pursuit of profit can overshadow stewardship and all too often negatively impact the natural environment. West Virginia is home to 251,000 NIPF landowners who hold over three quarters of the twelve million acres of forestland in the state (USDA Forest Service 2010c). Yet, during the fiscal year 2008 West Virginia's Forest Legacy Program (WV FLP) only acquired 764 acres of woodland (USDA Forest Service 2009) and had no acquisitions in 2009 (USDA Forest Service 2010c). Federal funds were available for the FLP in both years, and it is unclear why more acreage was not acquired. Independent organizations like the Land Trust of the Eastern 
Panhandle (LTEP) also have few participants in their (forestland) easement programs. Moreover, there are few, and possibly no, models available for studying the factors involved with landowners enrolling in conservation easement opportunities for environmental reasons or on forested land (Farmer et al. 2008). Therefore, this paper will evaluate conservation easements in the context of NIPF landowners in West Virginia. The specific objectives are to:

1) conduct a forensic policy analysis of the Uniform Conservation Easement Act of 1981, which was the pioneering legislation for easement programs and the foundation for the West Virginia Conservation and Preservation Act;

2) examine what affects landowner's decision to place an easement on their land; and

3) provide helpful information and possible recommendations that may increase NIPF enrollment. 


\section{Chapter II: Literature Review}

"The nation behaves well if it treats the natural resources as assets which it must turn over to the next generation increased; and not impaired in value."

-Theodore Roosevelt

\subsection{Historical Background}

\subsubsection{NIPF Background}

Individuals that own forestland, but do not operate timber-processing facilities, are called NIPF, and they hold most of the acreage in the United States (Cubbage et al. 1993). Because of the degree of woodland ownership by the private sector, decisions regarding property use could possibly have a significant effect on timber availability in the United States (Joshi and Arano 2009). In addition to already owning the lion's share of the 751 million acres of forest, the private sector continues to amass more land each year. In 1978, NIPF landowners owned 333.1 million acres of woodland in America (Birch et al. 1982) and by the early 1990's the amount had grown to 390 million (Birch 1994). The increase is staggering at approximately 57 million acres in less than two decades and the upward trend has continued into the twenty-first century. The amount of family forest owners grew eleven percent between 1993 and 2003 (Butler and Leatherberry 2004). And current estimations have the NIPF owning 423 million acres of forestland in the country (USDA Forest Service 2007).

Woodland acreage in the United States is privately owned by forest industry companies, other business corporations, partnerships, tribes, families and individuals (Butler and Leatherberry 2004). The forest service categorizes these groups as "noncorporate" and "corporate" and they own thirty-eight and eighteen percent of America's woodland respectively 
(USDA Forest Service 2007). Individuals make up about ninety-four percent of the private ownership demographic and hold fifty-nine percent of the private woodland (Birch 1994). Corporations have fewer owners but typically hold large tracts of forestland. They have twentyseven percent of the private woodland acreage; while the final fourteen percent is held by a miscellaneous category that includes joint ownerships, associations, Native American tribes and such (Birch 1994). The overall increase in privately owned forestland appears to be a mixture of individuals and corporations acquiring small, medium and large amounts of acreage. This is characterized in the statement that "forest ownership is far from static" (USDA Forest Service 2007, p. 21).

West Virginia's forestland is mostly owned by the private sector as well. And between the forest industry and service industry (e.g., tourism based employment), many residents of the state depend on forests for their economic livelihood (Jennings and McGill 2005). NIPF landowners own over eighty percent of the states woodland. Today there are 12,007,000 acres of forestland in West Virginia (USDA Forest Service 2010c). But between 1870 and 1920 the state's abundant timber resources were devastated when 30 billion board feet was harvested (Jennings et al. 2003).

In 1978 , there were roughly 207,500 private owners with an average of 49.8 acres (Birch et al. 1982). Currently, the private owners number at about 251,000 and hold $10,418,000$ acres (USDA Forest Service 2010c). When dividing the amount of West Virginia NIPF owners $(251,000)$ by their total amount of acres owned $(10,418,000)$, results show a decline in average acre per individual since the early 1980's (41.51), a trend which possibly reflects the current concerns over fragmentation and parcelization. Previous research has found the distribution of "noncorporate" and "corporate" private ownership to be sixty-three and twenty-five percent 
respectively, with partnerships and others owning the remaining twelve percent (Birch et al. 1982). This is an increase of individual private ownership in relation to the nation as a whole. In addition, the southern counties of West Virginia have the largest amount of corporately owned acreage (Birch et al. 1982).

Studies in the NIPF landowner arena were sparked initially by concern for a sustainable yield of timber and later compounded by higher demand in the better economy that followed World War II (Egan 1997). Eventually, research involving the NIPF shifted in the 1970's toward a focus upon the individual rather than the productivity of the land (Egan 1997). Yet, there is still a need for work that will further NIPF landowner involvement in forestry activities (Joshi and Arano 2009). Sustainable management by private landowners is vital to West Virginia for multiple reasons.

For starters, "Ninety eight percent of the forest land is considered timberland and available for timber production" (Griffith and Widmann 2003, p. 1) and NIPF landowners have majority ownership of that woodland in a state which is the second leading hardwood resource producer in the country, which means it is a large hardwood resource base (Joshi and Arano 2009). Therefore participation in conservation opportunities that allow forestry activities promises to be critical in the future. Yet, tailoring programs for this demographic is difficult because they are diverse and typically have varying objectives. Previous research has categorized NIPF owners into groups, based on their attitudes, for program development into four categories: 1) woodland retreat; 2) working the land; 3) supplemental income; and 4) ready to sell (Butler et al. 2007), a useful construct for programs targeting these individuals.

\subsubsection{History of Environmental Policy}


Modern environmental policy has emerged as one of the most important discussions in public administration today. Kraft and Furlong (2010) define environmental policy as, "all government actions that affect or attempt to affect environmental quality and the use of natural resources" (p. 342). In sum, environmental policy includes any legislation affecting the environment and economic development. The Punctuated-Equilibrium Theory offers an explanation for the sudden explosion in environmental policy during the 1970s. The theory contends that American policies evolve slowly over time, suddenly experience a short period of substantial change, then return to incremental advancement (Jones, Baumgartner and True 2007).

Environmental policy debuted on the American scene at the beginning of the seventeenth century and has been evolving ever since. Public policy regarding protection of the land was jump started in 1891 by the Forest Reserve Act (FRA) and gave the President authority to set aside land for public ownership. Concern for renewable resources prompted the formulation of agencies for their protection, such as the United States Department of Agriculture (USDA) Forest Service and the National Park Service. The events following World War II provided a new social conscience in the United States. This postindustrial era brought prosperity and the resulting well-rounded communities began to equate quality of life with the environment (Kraft and Furlong 2010). Public opinion drives policy and a legislative phenomenon ensued. The 1970s are considered the "environmental decade" because they produced a multitude of policies for environmental protection which has not been matched (Kraft and Furlong 2010).

The shift in public opinion during the 1970s generated modern environmental policies as well as regulatory agencies, such as the National Environmental Policy Act (NEPA) and the Environmental Protection Agency (EPA), which set the stage for conservation easements. The environmental movement includes several major policies that protect natural resources from 
harm. The most salient policy is NEPA which was enacted in 1970. A regulatory policy design type, NEPA requires an environmental impact statement (EIS) for anything significantly affecting the environment. NEPA gave the protection of natural resources national attention. The act did this by requiring public agencies to assess how their programs were effecting the environment; particularly on federal properties (Cubbage et al. 1993). This regulatory policy is enforced by the EPA, which is an independent executive agency that anwers to the President of the United States (Kraft and Furlong 2010).

Sustainable development is key to initiatives that involve natural resources and is essential when defining the environmental policy arena. The 1992 "Earth Summit" in Rio De Janeiro, Brazil was a global framework convention that reinvented environmental policy with sustainable development. These international treaties are not legally binding contracts but are influential in agenda setting and policy legitimation for individual countries. Cubbage et al. (1993) charaterize sustainable development as balancing economic growth with resource conservation. This United Nations conference sought to combine wise use of the environment with development in order to sustain our interdependant ecosystem.

\subsubsection{History of Conservation Easements}

Conservation easements have evolved alongside public opinion and natural resource policy. Also, the maturation of the environmental policy arena provides a baseline for the Uniform Conservation Easement Act (UCEA) of 1981, which is the most significant legislation regarding the alternative. "Though early protection of land can be traced to the New England colonies, it was not until the mid-1800's, and the Romantic Transcendentalist movement that land conservation and preservation emerged as a prominent feature on the landscape" (Farmer 2009, p. 15). Easements reportedly were used first during the 1880s in Massachusetts to preserve 
parkways conceptualized by Frederick Law Olmstead (Byers and Ponte 2005; Gustanski 2000). Mr. Olmstead invented landscape architecture in the United States and was the country's premiere designer for parks (National Park Service 2010). Acreage protected by this alternative gradually increased during the early part of the 1900s as well. Easements were used during the 1930s as an instrument to maintain scenic areas such as the Blue Ridge Parkway (Roe 2000).

William H. Whyte Jr. was an influential figure in the growth and development of conservation easements. Mr. Whyte was a decorated graduate of Princeton in 1939, served in the Marine Corp in the 1940s, rose to Assistant Managing Editor of Fortune magazine in the 1950s, before eventually departing to focus his professional career on open-space conservation (Whyte Jr. 1959). He later fashioned the term "conservation easement" in 1959 to give the alternative a positive connotation (Whyte Jr. 1959). The social shift and subsequent policies that occurred in the 1970s, as stated earlier, is evident in the maturation of conservation easements. The majority of states established regulations allowing the strategy between 1970 and 1990 (Byers and Ponte 2005). Again, the environmental decade and ensuing public policies set the stage for the conservation easement programs in place today.

The statutory history of conservation easements is complex; however, understanding the Tax Reform Act (TRA) of 1976, the Cooperative Forestry Assistance Act (CFAA) of 1978, the Uniform Conservation Easement Act (UCEA) of 1981 and the Food, Conservation, and Energy Act of 2008, also known as the "Farm Bill", are essential to understanding the background and current use of conservation easements. The programs available today are products of the environmental decade. During the 1980s easements began to grow in popularity, beginning with Internal Revenue Code 170(h). The Tax Reform Act (TRA) of 1976 was amended with 170(h) in 1980 to allow tax deductibility of conservation easements but the alternative was still widely 
misunderstood (Small 2000). This was a departure from the traditional authority tools favored for environmental laws. The tax breaks offered by 170(h) provided an inducement policy design type to private landowners and this incentive aspect of the alternative would prove to be key in the future popularity of conservation easements.

The Cooperative Forestry Assistance Act (CFAA) was legitimized in 1978. The purpose of this legislation was threefold. The objectives were to disperse appropriated funds for private forests to provide: 1) conservation and management of working forests; 2) protection from threats (including development); and 3) improvement of public benefit (CFAA § 8001). Amendments by the U.S. Farm Bill in 1990 enabled the legislation to support the USDA Forest Service's Forest Legacy Program (FLP). This program coupled with the United States Department of Agriculture's, Natural Resource Conservation Service (USDA NRCS) Healthy Forest Reserve Program (HFRP) are the only nationwide initiatives involving conservation easements. The FLP is currently available in 48 states and territories (USDA Forest Service 2010a).

The Uniform Conservation Easement Act (UCEA) of 1981 was pioneering legislation for two reasons. First, it is a template for individual states, and allows both government and independent agencies to contract easements with owners in order to protect and conserve land (Byers and Ponte 2005). Secondly, the legislation made common law variances between states uniform in order to serve the purpose of the act (UCEA § 6). Establishing a template for individual states gave local legislators the ability to tailor conservation easement laws to their regional need, such as the West Virginia Conservation and Preservation Act. This in turn negated common law hindrances across state boundaries that had previously impeded the progress of the alternative. The UCEA gave conservation easements national scope by superseding inhibiting 
state laws and is the statutory authority for most NGO easement programs. Since the enactment of the UCEA, conservation easements have become a valuable tool within the umbrella of sustainable development for protecting land in the United States as well as around the world.

The Food, Conservation and Energy Act of 2008 is the most recent version of the Farm Bill. The 2008 document legitimized support for commodity crops, horticulture and livestock, conservation, nutrition, trade and food aid, agricultural research, farm credit, rural development, energy, forestry, along with other initiatives (Johnson and Monke 2010). Similar to the UCEA, the farm bill allows governmental agencies to provide programs to both the public and private sector. This legislation enables the USDA NRCS to provide programs such as the HFRP, the Farm and Ranchland Protection Program (FRPP), Grassland Reserve Program (GRP) and Wetland Reserve Program (WRP) and many others.

Legal documentation concerning acquired property has become more sophisticated in recent years. Loopholes from vague restrictions in early easement documents led to unforeseen consequences that had negative outcomes. Land trusts learned a lesson from those contracts where, despite development guidelines, subdivision caused problems and organizations had to plan for the possibility of multiple landowners (Rissman et al. 2007a). Since then, conservation easements have increased in complexity, allowing for multiple use of the land; which may require management plans and approval for operations in the future (Byers and Ponte 2005). Multiple uses beyond restriction of development may include working forest conservation easements (WFCE's) or preservation of wildlife and biodiversity. In fact, buying conservation easements may prove essential to habitat protection due to policy issues. Armsworth and Sanchirico (2008) point out that a "substantial investment to purchase properties or compensate 
landowners will be required to expand habitat conservation efforts, because major enlargement of statutorily protected areas is unlikely" (p. 182).

\subsection{Structure of Conservation Easements}

Conservation easements typically restrict development of the land permanently and management plans often are included in the agreement documentation but are not required (Mortimer et al. 2007). In fact, a study in 2007 surveyed 119 conservation easements held by The Nature Conservancy (TNC) and nearly every contract was designed to minimize development (Rissman et al. 2007a). Some easements are established for a specified time period and are called term agreements or management leases, although these contracts are not eligible for tax incentives (Byers and Ponte 2005). Partial retention of ownership rights is another important part of the overall structure. The bundle of rights illustration is often used; where the "ownership bundle" is like having a bundle of sticks; each stick representative of an individual property right; with conservation easements usually removing the rights (or sticks) pertaining to development (Gustanski 2000). One misconception of conservation easements is that they only restrict development rights. The term PDR (purchase of development rights) began being used incorrectly when referring to easements; when in fact PDR means state and regional programs that deal exclusively with development rights (Gustanski 2000).

Conservation easement agreements are dense and lengthy legal documents and can be quite specific with regard to established restrictions. Agreements may identify the amount, design and size of development, as well as establish a building envelope; which is defined as a small area that can have new structures (Rissman et al. 2007a). Although requirements may vary from state to state, a model conservation easement follows a general format. Documents usually 
contain a caption, recitals, grant, provisions, habendum, signatures and acknowledgements and supplementary provisions (Barrett and Diehl 1988). Conservation easements are intended to meet several needs for landowners beyond development restriction and can allow a variety of commercial activities; therefore stipulations appear along a gradient from firm restriction to specific permitted land uses (Rissman et al. 2007a). Following formulation and implementation

of the agreement, the landowner is required to supervise use of the land whereas the agency must enforce the terms of the easement (Gustanski 2000). In essence, both grantor and grantee have an ongoing commitment to adhere to the guidelines set forth in the conservation easement.

\subsection{Financial Benefits and Conservation Easements}

Tax benefits are a key part of the conservation easement structure but there are several stipulations. Land eligible for tax deductions must be used for public recreation or education, significant natural habitat, scenic enjoyment, local government policy fulfillment (including farmland and forestland) or historic preservation (Wallace et al. 2008; Byers and Ponte 2005; Barrett and Diehl 1988). Tax incentives not only require criterion for the type of land but also for the type of donation as well. Rights must be transferred below fair market value, in perpetuity, for conservation purposes and to a qualified conservation organization (Barrett and Diehl 1988). Once these requirements are met, conservation easements offer a degree of flexibility within the agreement. For instance, conservation easements can affect the land in its entirety or restrict prescribed areas in different ways (Byers and Ponte 2005).

The value of a conservation easement is the difference between two federally approved appraisals. Typically the landowner is required to have the parcel appraised at its fair market value twice, both before and after restrictions are legitimized by the conservation easement; the 
variation between these prices is the monetary worth of the easement for charitable donation purposes (Byers and Ponte 2005). These appraisals bypass what Small (1997) calls "mixedincompatible-uses" by assessing the surface rights apart from the sub-surface or mineral rights. Once the value of the conservation easement is established, the landowner can choose how the financial benefits are paid to them.

There are three methods of payment available to the grantor of a conservation easement. Purchasing the in-kind donation provides landowners with the full amount up front. Donating the easement means the monetary value will be deducted from the landowner's gross annual income. This deduction can often be spread out over several years depending on the tax situation and needs of the donor. A combination of both purchasing and donating the conservation easement is the final option and is the one most commonly utilized. In this scenario, the landowner receives less than the full amount of the monetary worth and then donates the remaining value for tax deductions; this is referred to as a bargain sale (Small 2005). In addition, this is also the method of payment frequently used in the state of West Virginia (Hatton 2011).

All land is not necessarily created equal when it comes to market and conservation value. Property with valuable timber or soil, as well as endangered wildlife or historic structures may be higher in priority to government and independent agencies for acquisition. Usually, land value is directly correlated to its availability for development, which is the reasoning for the voluntary nature and two forms of monetary inducements; tax benefits from participation and purchasing the property with public funds (Blaine et al. 2003). Nevertheless, landowners should seek professional advice on the best payment alternative for their conservation easement. The amount of tax deductions accumulated incorporates many factors such as gross annual income, value of 
the easement in proportion to aforementioned income and other exemptions claimed by the landowner (Small 2005).

\subsection{Examination of Programs in West Virginia}

Much like the rest of the country, West Virginia has several organizations that offer easement programs to private landowners. The West Virginia Division of Forestry (WVDOF) provides cost-share opportunities for conservation easements to forestland owners through the federal FLP. The USDA NRCS provides conservation easement programs to numerous landowners in the state with programs such as the HFRP, the FRPP, the GRP and the WRP. However, although the HFRP is federally mandated, it has been difficult to implement due to lack of funding (Hatton 2011). This may be a larger contributor to lesser participation in forestland easements then similar woodland programs dispersing enrollment (Hatton 2011). In fact, when private landowners are involved in other programs they typically engage in more forestry practices (Jennings and McGill 2005).

Independent land trust agencies accept easements from the state's private sector through several non-profit organizations. These land trusts are located throughout West Virginia with a few, such as the Potomac Conservancy, being located out of state. The Coalition of West Virginia Land Trusts is organized by the West Virginia Land Trust and comprised of the Indian Creek Conservancy, the West Virginia Cave Conservancy, Cacapon and Lost River Land Trust, Potomac Conservancy, Land Trust of the Eastern Panhandle, Greenbrier Land Conservation Trust, The Nature Conservancy, Trust for Public Land and the National Committee for the New River (West Virginia Land Trust 2010). Statutory authority allowing these organizations to 
accept easements in the state comes from the West Virginia Conservation and Preservation Act. This being legislation that was born out of the UCEA (Anderson 1997).

The FLP and the NRCS, along with the Coalition of West Virginia Land Trusts allows conservation easements to be accessible across the entire state. The NRCS enrolled 3,793 acres and obligated 5,641,912 federal dollars through the FRPP program alone during the 2010 fiscal year (USDA NRCS 2011). Statewide publicity for NRCS programs is largely comprised of local outreach such as public news releases, newspapers and radio interviews (Hatton 2011). Yet, there is a need for better outreach; particularly at the regional level for the eastern panhandle and Greenbrier Valley areas of West Virginia (Hatton 2011).

There are 17,750 acres of land protected by conservation easements in the state which has aided in curtailing subdivision (The Nature Conservancy 2010). The Land Trust of the Eastern Panhandle (LTEP) has three forestland easements for a total of 270 acres; one in particular covers 100 acres and is a WFCE (Smith 2010). In addition, the Smoke Hole is an easement near the Potomac River that covers 1,126 acres and provides a buffer for the Monongahela National Forest (The Nature Conservancy 2010). Wallace et al. (2008) define a buffer zone to be a privately owned parcel sharing a boundary with land protected for the public. With multiple uses and flexible drafting processes that can address diverse objectives, conservation easements are an important policy instrument available to landowners in West Virginia.

\subsection{Examination of Programs in Other States}

Conservation easement programs in other states across the nation are sustained by a multitude of organizations as well. Government and independent organizations conserve land, but NGOs are becoming more important since they are not impeded by political changes 
(Fishburn et al. 2009). As mentioned earlier, the federal FLP and HFRP are the only nationwide programs involving conservation easements. The Nature Conservancy (TNC) is likely the most well-known independent organization. The TNC is a non-governmental organization that is international in scope and requires board consent for large purchases (Fishburn et al. 2009).

The Land Trust Alliance (LTA) is a nationwide coalition of land trusts which sets standards for accreditation and provides resources and training for local land trusts. According to them, there are more than 1,200 NGOs in America with most of them located in the northeast (Merelender et al. 2004). This amount of decentralization produces a challenge in making comparisons between states. A recent study could find no data sets at the state-level for conservation easements; data such as their locale, landowners, type of land, or their proximity to other easement property (Merelender et al. 2004). Moreover, the general debate about conservation easements has continued with little data about conservation easement contracts, particularly in the national context (Rissman et al. 2007a). More recently, the USDA has begun using a program called the National Easement Staging Tool (NEST) which tracks and records all federal interests in terms of NRCS conservation easements and is attempting to centralize data and increase efficiency (Hatton 2011).

Another way to assess variation would be to look at an exemplary conservation easement from another state. The Pingree conservation easement in Maine protects 762,192 acres of forest and is the largest of its kind in the United States (Sader et al. 2002). Monitoring is an obstacle for conservation easements but the agency responsible for monitoring the Pingree easement, The New England Forestry Foundation (NEFF), is developing a cutting edge approach to the problem. The NEFF generated a three-pronged monitoring system that involves satellite imagery for change detection, aerial photography and field visits (Sader et al. 2002). Moreover, the 
Pingree conservation easement sets the standard for private landowners who wish to take advantage of tax incentives, provide management for their forest and achieve conservation goals (Sader et al. 2002). A good model for an efficient forestland conservation easement can help improve programs in West Virginia and aid in increasing NIPF landowner participation.

\subsection{The Impact of Conservation Easements}

Conservation easements have increased dramatically in popularity and use since the early 1980s. In 2003, the LTA conducted a census of NGOs that revealed more than 5 million acres conserved by over 17,847 easements in the United States (Byers and Ponte 2005). The FLP has protected an additional 1,855,222 acres nationally (USDA Forest Service 2010a). The USDA NRCS has five separate easement programs that target specific objectives and have impacted conservation efforts nationwide. Federal programs and independent agencies together have caused the easement alternative to significantly affect the entire country.

Conservation easements have become a legitimate tool for land protection worldwide as well as in the United States (Mortimer et al. 2007). Despite the global impact of conservation easements, there does not appear to be many private woodland owners participating in conservation easements in West Virginia. The West Virginia Land Trust (WVLT) holds roughly 10 easements that are mostly farmland (Young 2010). While the Land Trust of the Eastern Panhandle (LTEP) only has three (forested) easement acquisitions (Smith 2010) and the FLP obtained no new acreage in 2009 (USDA Forest Service 2010c). An evaluation of NIPF landowners in West Virginia can shed light on why this increasingly popular instrument appears to have few NIPF participants in the state. It may also offer possible recommendations and useful information for local and national programs as well as NIPF. 


\section{Chapter III: A Forensic Policy Analysis of the Uniform Conservation Easement Act (UCEA) of 1981}

"Examine each question in terms of what is ethically and aesthetically right, as well as what is economically expedient."

-Aldo Leopold

\subsection{Introduction}

The core of all land management and preservation issues is the legislation that precedes the choice concerning the resource (Gustanski 2000). A forensic policy analysis is an attempt to identify the fundamental causes that resulted in current polices. Kraft and Furlong (2010) contend that the activity can include many components but that, "Policy analysis usually involves collecting and interpreting information that clarifies the causes and effects of public problems and the likely consequences of using one policy option or another to address them" (p. 98). Since conservation easement usage steadily increased following the enactment of the UCEA in 1981, an analysis of the policy is worthwhile.

As mentioned above, the UCEA lengthened the reach of conservation easement programs in the United States. The policy effect was twofold in that it provided a model for local level legislation to be enacted; which then gave conservation easements immunity to the complexity and differentiation in laws from state to state. Much like conservation easement legislation at the national level, the West Virginia Conservation and Preservation Act gives economic incitement to private individuals for agreeing to not develop their property (Anderson 1997). This legislation increased the viability and enabled the use of conservation easements as a land management tool in the state of West Virginia, a direct result of the UCEA of 1981. More than one hundred years ago, Mark Twain realized the limits of land as a resource and the issue is even more important today (Kelly 2010). The following analysis attempts to identify the problems 
leading up to this influential policy, along with suggesting alternatives and possible recommendations for the future.

\subsection{Forensic Policy Analysis}

\subsubsection{Problem Definition}

Deborah Stone (2002) contends that debates over public policy are mostly about fundamental causes and that addressing the side effects is insufficient. Kraft and Furlong (2010) concur with Stone that the decision to either focus on the heart of a policy problem or the readily attainable proximate causes is an ongoing dilemma in policy analysis. Solutions to environmental problems are long term by nature and the flaws within quick fixes are eventually revealed. Previous legislation for land protection such as the Forest Reserve Act (FRA) of 1891 established and protected land for the public but did nothing for private land. Also, the direct regulation policies from the environmental decade focused on pollution rather than open-space; a term commonly used in reference to undeveloped land. Though previous policies regarding the environment were enacted in good faith, and believed to be in the best interest of the public at the time, there were still problems that had not been addressed. Problems like protecting and preserving private land against urbanization and overconsumption while allowing individual owners to retain property rights.

The causes of this problem are debatable. Literature about conservation easements alludes to three possible determinants; these causes can be placed within a theoretical framework. Deborah Stone (2002) offers categories within which we can conceptualize these issues for analysis; she says that symbols, causes, interests and decisions are helpful in defining problems that result in public policy. She also identifies causes as the foundation of problems, 
and that such problems cannot be expounded without addressing their causal antecedent (Stone 2002). The literature points to several issues that have contributed to the problem and they fall into Stone's symbolic category.

The symbolic approach states symbols are representative of a problem, and that narratives are symbols (Stone 2002). There are three narratives of the problem that eventually resulted in the enactment of the UCEA. The first causal story is that of encroaching development and the decline of open-space. This problem is the most salient; it is the story about the gradual loss of American wilderness, which has been a topic of debate in the state West Virginia.

A recognized problem, the decline narrative is powerful in communicating urban sprawl and how development continuously threatens the viable existence of open-space in the United States. The presence of undisturbed land in America is limited, impossible to regain once lost and a causal story that generates compounding problems. For example, timber harvesting decimated high elevation forests in West Virginia in the past. In fact, logging at the beginning of the $20^{\text {th }}$ century significantly reduced red spruce (Picea rubens) distribution and the wildfires that followed devastated the population; second growth re-establishment has been relatively small in relation to the magnitude of the original forest (Zinn and Sutton 1976). Such events produced a nationwide fear of timber famine and protection of the resource became an immediate priority. However, protecting natural resources has now evolved to include fragmentation and parcelization caused by development, degradation of wildlife habitats, sustainable forestry, farming, and erosion from flooding (Mortimer et al. 2007).

Dvora Yanow (1995) asserts the importance of policy meanings and that deducing them is difficult; she defines the practice as a conscious endeavor of interpretation. In essence, it is not 
easy to determine which problem is the original cause for public policies; however, the context provided by the UCEA itself sheds light on the dilemma. The first section of the UCEA (“definitions") provides insight for defining the situation. The following technical definition implies that the problem, as described by the decline narrative, was an influential factor in legitimation of the Act:

Conservation easement means a nonpossessory interest of a holder in real property imposing limitations or affirmative obligations the purposes of which include [a] retaining or protecting natural, scenic or open-space values of real property, [b] assuming its availability for agricultural, forest, recreational or open-space use, [c] protecting natural resources, [d] maintaining or enhancing air or water quality, or [e] preserving the historical, architectural, archeological or cultural aspects of real property. (UCEA § 1) According to Gustanski (2000) protecting open-space and culturally rich land can be found in the policy context. So, it is within this policy language that we find indicators, such as retaining, protecting, preserving and maintaining — that allude to the decline narrative being a valid causal factor.

Due to urbanization and other side effects of population growth, undeveloped land is under a constant threat. This problem is closely connected to the next causal factor which is overconsumption of natural resources; an issue that historically has not been uncommon to the state of West Virginia. This symbolic narrative began at the turn of the twentieth century; when commercial logging, as mentioned previously, over consumed forest products across the United States; most notably that of West Virginia's high altitude subalpine coniferous forest. Despite efforts by the US Forest and National Park Service, open-space losses continued well into the century. During the 1950s it was clear that specific conservation tools were needed to fight the 
decline. Max Wehrly, Executive Director of the Urban Land Institute in the 1950s, argued that decreases in open-space should be an increasing concern for anyone who holds the welfare of the nation at heart (Whyte Jr. 1959). These developments lead government and independent agencies to depend more on policy instruments, such as conservation easements, to protect forestland (Mortimer et al. 2007).

Development pressure and overconsumption greatly affects natural resources. Individual owners control the majority of open space, especially with regard to forestland. Fifty-six percent of the resource is owned by the private sector, while public agencies hold forty-four percent of the woodland in America (USDA Forest Service 2007). This majority ownership is greater in West Virginia where approximately eighty-five percent of forestland is privately owned (USDA Forest Service 2010c). Therefore, private landowners are an important demographic in defending against urbanization at both the local and national level, and selling sensitive land to developers is an ongoing temptation.

A lesser known narrative is one of widespread distrust of government by the private sector. This third causal story is of the American people's desire to retain and protect their private property rights. Many landowners may wish to place perpetual easements on their land but refrain because they do not want the government to impose restrictions upon them. Individuals refuse to compromise their land rights and apprehension toward federal agencies adds fuel to the fire. "At present, governmental land-use planning and federal land acquisition seem too widely perceived as a threat to private property rights to be a useful broad-scale conservation strategy" (Merelender et al. 2004, p. 66); especially in West Virginia. 
The conversation surrounding these problems in the literature does not reveal much conflict over their causal influence. Widespread approval for the protection of natural resources gave birth to the environmental decade; an un-paralleled legislative phenomenon. This is a possible explanation for the lack of debate surrounding these issues. Nevertheless, literature has revealed three problems that, each in their own right, may be the story that led to legitimation of the UCEA. These causal factors are defined as: 1) encroaching development and the decline of open-space; 2) overconsumption of natural resources; and 3) the American people's desire to retain and protect their private property rights. My position as an analyst is that the UCEA, and consequently the West Virginia Conservation and Preservation Act, is a product of these problems working synergistically.

\subsubsection{Tools and Alternatives}

Public policy needs continuous improvement due to the intricacy of societal problems (Kraft and Furlong 2010).The environmental decade provided several laws for the preservation of natural resources. This was a good start but it did not take long for the policy process to forecast a need for change. Policies generated during the era were effective, but as mentioned previously, problems remained that needed to be addressed. Kraft and Furlong (2010) point out that each of the seven major environmental policies generated in the 1970s (NEPA, the Clean Air Act, the Clean Water Act, the Federal Insecticide, Fungicide and Rodenticide Act, the Safe Drinking Water Act, the Resource Conservation and Recovery Act, and Superfund) are regulatory, or what detractors term command and control policies. These authority tools were able to alleviate negative impacts on the environment from pollution but insufficient in curtailing open-space losses caused by development. Still, conservation easements may benefit from the status quo and its regulatory policy design type. 
Merelander et al. (2004) believe organizations providing conservation easement programs need authority to revise perpetual easement contracts in light of changing conditions. In response, the government could assess the need for modifications to the document, or allow the monitoring agency to perform the task. This regulatory alternative to the problem could determine whether previous restrictions are no longer in the best interest of the property. For instance, "What happens if the easement prohibits all land uses but ranching becomes economically nonviable in the region?" (Merelander et al. 2004, p. 67). In this case a regulatory alternative would be appropriate. An authorized independent or government organization could inspect and assess the current needs of the land and its owner, then consent to or deny the drafting of a new conservation easement. Therefore, direct regulation of open-space continues to have value and a status quo alternative (no UCEA) requiring no change in policy is a viable option.

So, until the enactment of the UCEA, the government was exercising an authoritarian approach for all environmental policy and direct regulation needed to be integrated with new alternatives to accommodate diverse private landowners. Also, a new option was needed for protecting natural resources in order to curtail open-space losses caused by development. It came in the form of incentives. Again, Deborah Stone offers a framework for both regulatory and incentive alternatives. "Rules" demand individuals to behave in a particular way, while "inducements" adjust behavior with benefits or disciplinary action (Stone 2002). Merelander et al. (2004) cite a backlash by landowners that negatively impacted conservation; they resented both the command and control policies and the government organizations that drove them, which were believed to embody expensive bureaucracy, gridlock and disinterest. Authority tools no 
longer addressed the evolving environmental protection issues and the UCEA enabled widespread use of inducements as a policy instrument for conservation.

As mentioned briefly before, there are two sides to the inducement tool and Kraft and Furlong (2010) define the alternative as either encouraging individuals to comply via inducements, or discouraging non-compliance through sanctions. The UCEA chose to encourage landowners to place conservation easements on their property with incentive-based inducements. The TRA of 1976 enabled tax deductions for easement property but the UCEA allowed the alternative to be utilized across the country. The enormous amount of acceptance for incentives offered by conservation easements may have arose from landowner dissatisfaction with command and control policies, although measuring the outcomes of the easement approach is challenging due to the many individuals and organizations involved (Merelander et al. 2004). Determining the effectiveness of conservation easements is elusive and a long-term endeavor but the popularity of inducements as a policy tool is clear. The Nature Conservancy, in 2003, recorded protecting more than 1,820,722 acres of land in America using conservation easements (Byers and Ponte 2005).

The decisions approach states that policy problems are all properties of the larger problem of goal oriented decision making (Stone 2002). It advocates the involvement of economic analytic tools and logic for policy legitimation. The ability to recruit and accommodate a large number of landowners through inducements rather than regulation is logical in a costbenefit scenario. Easement acquisition is dependent on private retention of rights, discretionary involvement and incentives; these elements allow more land to become protected by lowering costs and side stepping the politics involved with public acquirement of land (Merelander et al. 2004).The problem arises when attempting to target diverse landowners across state boundaries. 
This would require uniformity in law that the UCEA eventually provided. In other words, protecting the land with conservation easements is pareto efficient and a rational decision would be to enact legislation in support of the alternative.

Favorable public opinion toward tax incentives and accommodating the immense target population of private landowners are not the only reasons inducements became the primary tool for conservation easements. A possible underlying theme to publicly perceived policy problems is government failure (Weimer and Vining 1999). Authority tools, despite their overall effectiveness, were failing to address the totality of the circumstances surrounding environmental policies. Harkening back to the decisions approach, incentives are one solution to a larger problem and are an example of a rational decision making process. In turn, this type of legislation offers a free market substitute for land use regulation (Anderson 1997).

One argument for demand-side or in-kind subsidies is that the commodity in question creates a positive externality (Weimer and Vining 1999). For example, a conservation easement donation in West Virginia could directly benefit a NIPF landowner financially; while indirectly benefiting the public by sustaining and/or preserving the resource. In addition, conservation easements create an avenue toward sustainable development by helping to keep active landscapes, such as farm and forestland, in production. "By using a tool called a working forest conservation easement (WFCE), foresters and landowners can protect managed forests from development and keep working forests working" (Frame 2009, p. 1). In essence, incentives are the policy instrument utilized by conservation easements for a variety of reasons and continued employment of the UCEA is a reliable alternative. 
Despite the popularity of conservation easements as provided by the UCEA, there are valid criticisms that allude to the next alternative. The perpetual nature of easements forecast a problem and the solution requires privatization. Merelander et al. (2004) questions the institutions saddled with enforcing the provisions of contracts; what happens to the permanence of conservation easements if these institutions are unstable? Kraft and Furlong (2010) define privatizing as converting public services from government to independent organizations. In the privatizing approach, the EPA would acquire and maintain a database of agencies providing conservation easements and upon the dissolution of an organization the EPA would contract out the abandoned easements to NGOs. The key element to this approach is government disbursing responsibility among independent agencies; and therefore is a privatizing alternative.

Knowledge is power and educating the general public is also a viable option. Kraft and Furlong (2010) describe this alternative as actively facilitating information to the polis in a variety of ways, including formal programs. One of the biggest obstacles for conservation easements is lack of knowledge; even individuals who believe they are informed about the alternative are really not aware of all the nuts and bolts (Saville 2010). Landowners formulate their own contracts and ultimately decide what restrictions are placed on their property. However, "they don't realize you draft the easement in the affirmative and negative, people don't understand that you make the easement say what you want" (Saville 2010). The attentive public may be aware of this but the general public is usually skeptical when it comes to restricting private property rights, especially if a government agency is involved. Current technology provides many avenues to communicate information such as public service announcements (PSAs), outreach programs, internet, television and many more; the education alternative has the ability to be both national and global in scope. 
Peter Deleon (1997) advocates an alternative called participatory policy analysis (PPA), which incorporates and educates citizens into the dialogue over policy debates. In addition to the education alternative, participatory policy analysis could improve old policies as well as generate new tools for the UCEA. First of all, there are many misconceptions about environmental issues circulating in the polis. Kraft and Furlong (2010) agree that the public has a distorted view of important issues; which result in environmental policies that do not always protect the community's health. More specifically, one of the biggest problems for the UCEA has been lack of knowledge. As mentioned earlier, the general public is unaware that conservation easements can be formulated to accommodate individual goals and objectives. Although education is not a "one size fits all" strategy, it is a vital tool and a good alternative.

In summary, the regulatory approach has been effective in the past and a no policy change alternative is an option. Still, inducements have made conservation easements an extremely popular policy instrument and continued use of the UCEA is an option as well. There are other feasible strategies that may be good additions to the already established regulatory and inducement tools. One is a privatizing approach where the government contracts out easements to independent agencies. Another is an education alternative that integrates mass media and participatory policy analysis to inform and incorporate the general public. The four alternatives outlined here are: 1) no policy change; 2) the UCEA; 3) privatizing; and 4) education.

\subsubsection{Comparing Alternatives}

When comparing alternatives it is important to re-establish and stay connected to the baseline for the problem. This baseline is the three causal stories derived from the literature: 1) encroaching development and the decline of open-space; 2) overconsumption of natural resources and 3) the American people's desire to retain and protect their private property rights. 
In recent years, sustainable development has symbolized the current solution to the decline of open-space. Still, these narratives initiated the public concern for natural resources and, in concurrence with the Punctuated-Equilibrium Theory, generated a sudden onslaught of policies. This evolution created the framework for environmental legislation and must be kept in mind when comparing alternatives. Ultimately, outcomes from chosen alternatives must address the baseline problems.

The criterion for evaluation will be effectiveness, administrative feasibility (efficiency) and ethics. Kraft and Furlong (2010) define effectiveness as the ability to attain program goals. Administrative feasibility is the probability that an organization can implement the alternative effectively (Kraft and Furlong 2010). It also includes assessing the alternative in a cost-benefit scenario and therefore is closely related to efficiency. Ethics is commonly described as a philosophy for moral standards. Ethics for this analysis will be defined as whether or not the policy outcome infringes on private property rights. Table 3.1 categorizes the four alternatives in a decision matrix commonly used in policy analysis. Also, Bardach (2005) points out that keeping unforeseen impacts in mind is an important endeavor, "Analysts are often cautioned to think about unanticipated consequences" (p. 137). 
Table 3.1: Decision matrix for comparing UCEA policy alternatives.

\begin{tabular}{|c|c|c|c|}
\hline Alternative & Effectiveness & Administrative Feasibility & Ethics \\
\hline $\begin{array}{l}\text { No Change } \\
\text { (Regulatory) }\end{array}$ & $\begin{array}{l}\text {-- Landowner distrust in } \\
\text { government organizations } \\
\text { is a detraction }\end{array}$ & $\begin{array}{l}\text { + Proven feasible for } \\
\text { program implementation }\end{array}$ & $\begin{array}{l}\text {-- May infringe on private } \\
\text { property rights }\end{array}$ \\
\hline $\begin{array}{l}\text { UCEA } \\
\text { (Inducement) }\end{array}$ & $\begin{array}{l}\text { + Proven reliable in } \\
\text { attaining program goals }\end{array}$ & $\begin{array}{l}+ \text { Proven feasible for } \\
\text { program implementation }\end{array}$ & $\begin{array}{l}+ \text { Does not infringe on } \\
\text { private property rights }\end{array}$ \\
\hline Privatizing & $\begin{array}{l}+ \text { Helps to defend against } \\
\text { organizational dissolution }\end{array}$ & $\begin{array}{l}\text {-- Acquiring and } \\
\text { maintaining large database } \\
\text { difficult }\end{array}$ & $\begin{array}{l}\text {-- May infringe on private } \\
\text { property rights }\end{array}$ \\
\hline Education & + Knowledge is power & $\begin{array}{l}\text {-- Funding, manpower and } \\
\text { time constraints may inhibit } \\
\text { PPA }\end{array}$ & $\begin{array}{l}+ \text { Does not infringe on } \\
\text { private property rights }\end{array}$ \\
\hline
\end{tabular}

The no change alternative is not likely to achieve program goals sufficiently and received a minus in the effectiveness category. Again, the literature and historical background has shown that the private sector is suspicious of government organizations and regulation, particularly when it involves personal property. Administrative feasibility is a plus for this option because regulatory tools are commonly used and easily implemented. Yet, it failed the ethical evaluation because any organization with the power to revise a legally binding contract could infringe on private property rights. This does not allow the no policy change alternative to further conservation; moreover, it was one of the reasons inducements became widely used. Landowners that wanted to retain private property rights preferred inducements over regulation and favored the voluntary aspect of such initiatives (Merelander et al. 2004). A possible unintended consequence of no policy change could be resentment toward authority that may lead to apathy toward environmental issues, and ultimately a failure to protect the resource. 
Evaluation of the second alternative, the UCEA, provided good results. Inducements have shown the ability to impact all three evaluative criteria positively and have been an effective, feasible and ethical instrument for land management. Over the course of fifteen years, 1988 to 2003, usage of conservation easements by land trusts increased 1,624 percent (Byers and Ponte 2005). Conversely, the perpetual aspect of the alternative may cause an unanticipated consequence. Specifically, one critique of the continued usage of the inducement alternative involves the multiple streams theory. This theory states that policy is a result of the convergence between three streams: policy, problems, and political; once this fusion happens and a window of opportunity arises, new public policies are legitimized (Sabatier 2007). Mortimer et al. (2004) contend that the economic and political situations that have driven organizations and conservation easement programs are temporary, and that the ensuing restrictions will outlast the ecological and social conditions that allowed them.

Privatizing, the third alternative in the matrix, may have positive outcomes in the effectiveness category. Although local agencies are subject to possible organizational failure, the amount and decentralization of American NGOs would allow new agencies to pick up the slack. Administrative feasibility may be a weakness for this alternative because acquiring and maintaining such a large database would be difficult for the EPA. Also, privatizing may infringe on private property rights because it does not allow the individual landowner to choose the conservation organization that holds their easement. Yet, the sheer number of NGOs in the United States helps defend against organizational disillusion. In fact, the 1,537 independent agencies in the United States often prefer conservation easements as a means for protecting land (Byers and Ponte 2005). Conflict between organizations over available easements may be a negative consequence. 
Finally, the last alternative is education; knowledge is power and educating citizens is an attainable goal. Combining mass media and participatory policy analysis is a promising alternative for conservation, but there are problems that may accompany the positive outcomes. Funding, manpower and time constraints are likely to be difficult hurdles to overcome for participatory policy analysis. Nevertheless, education does not infringe on private property rights in any context. Whether it be participatory policy analysis, online or in a classroom; knowledge is a vital tool for environmental protection. In an effort to educate the population, along with professionals, the West Virginia Land Trust utilized webinars, video conferences and seminars (Saville 2010). However, global marketing could leave small-scale organizations vulnerable to scams and criminal activity.

There are several likely reasons why the UCEA was enacted. First and foremost, the three baseline problems were the fundamental causality for the legislation. Although the environmental decade and its regulatory policies were, and continue to be, effective, they eventually forecasted the need for a new alternative. I would not change the decision making that legitimized the UCEA. I believe the positive inducements offered by conservation easements are currently the best alternative for land conservation in West Virginia and the nation as a whole.

\subsubsection{Recommendations}

A review of the analysis shows the literature clearly defines three root causes; 1) encroaching development and the decline of open-space; 2) overconsumption of natural resources and 3) the American people's desire to retain and protect their private property rights. Data from academic journals, books and professional sources have provided sufficient evidence that lack of open-space and overconsumption of natural resources pose a long-term threat to such resources as well as private property rights. Four alternatives have been evaluated for solving 
these fundamental issues; 1) no policy change; 2) the UCEA; 3) privatizing; and 4) education. Outcomes for each option were measured in a decision matrix by three criterion; 1) effectiveness; 2) administrative feasibility; and 3) ethics. The trade-offs between each approach were examined. Finally, the UCEA alternative proved to be the best solution. Both at the national level and on the local level; especially for states with large amounts of natural resources such as West Virginia.

This recommendation is guided by an attempt to incorporate both a prudent and objective analytic approach. Within the decision matrix, inducements were consistently better across the board. In fact, it was the only approach that received positive marks in each evaluative category. Moreover, the private sector owns most of the natural resources in the United States, with majority ownership even more prevalent in the state of West Virginia, and the UCEA provides accommodation for this large target population. Ultimately, inducements are the most efficient approach to addressing the root causes of environmental problems.

The great conservation opportunities of this century will be on privately owned land, and conservation easements are the most effective way to protect those lands. Landowners like conservation easements because they are a refreshing alternative to government regulation: they are voluntary, local, and respect private property rights. Rand Wentworth, President, Land Trust Alliance (Byers and Ponte 2005, p. 7).

The enormous amount of popularity for this alternative projects usage to continue trending upward, and therefore government and non-governmental organizations that accept conservation easements are important institutions. Easements have shown rapid growth and, nationally, the private sector has demonstrated a commitment to defending against development by using land trusts (Gustanski 2000). 
The UCEA alternative is my recommendation but a degree of integration from each option will be important for the future. Collaborative decision making attempts to solve local and regional problems concerning the environment (Kraft and Furlong 2010). Such an approach will help decision makers assess which policy alternatives address the needs of their district, such as the requisites in West Virginia versus those in the southwest. Regulation may work better if an area has more corporate landowners than private individuals. Furthermore, privatizing may help states with newly established land trusts maintain conservation easement contracts. Lack of knowledge has been one of the biggest obstacles for conservation easements and education can address environmental issues on the local and national level. Compromise with processes such as collaborative decision making embodies the concept of sustainable development, and should be practiced when implementing and evaluating environmental policies.

Due to the perpetual nature and recent popularity, continuous research and development is needed for this alternative, particularly in states like West Virginia where participation does not appear to be abundant. For example, the West Virginia Division of Forestry's Forest Legacy Program (FLP) did not acquire acreage during the 2009 fiscal year (USDA Forest Service 2010c). Evaluating the environmental impacts of conservation easements over time will shed light on their effectiveness. Innovative and efficient monitoring and enforcement regimes should to be generated and implemented. Easement documents should not be drafted carelessly and should reflect the needs of both landowner and the particular property. At this time, continued usage of the UCEA policy alternative is the appropriate strategy, but regular evaluation and revision is vital to the ongoing relevancy of this approach.

In order to project the likely outcomes, policy makers must continue to look at the context in which problems are derived. The environmental policy arena involves outcomes that 
are not determined quickly. Therefore it is imperative to produce policies that are believed to address the causal stories. Public opinion drives policy and doing what is right is not always politically popular. Nevertheless, compromise and collaborative decision making are essential components to environmental policy, sustainable development, the UCEA and the state of West Virginia in the future. In sum, conservation easements and their enabling legislation are important to moving forward, and according to Anderson (1997), "The West Virginia Conservation and Preservation Act is certainly a land management device whose time has come in West Virginia" (p. 6). 


\section{Chapter IV: Modeling Likelihood to Participate in Forestland Conservation Easement Programs}

"Pure mathematics is, in its way, the poetry of logical ideas"

$\sim$ Albert Einstein

\subsection{Introduction}

Research regarding conservation easements has often focused on the easement alternative as opposed to the landowner. There have been several studies concerned with the environmental and economic aspects of these legally binding contracts (Armsworth and Sanchirico 2008, Kiesecker et al. 2007, Mortimer et al. 2007, Rissman et al. 2007a, and Merelander et al. 2004). Conversely, few projects have looked at the general motivations of landowner participation and even fewer have targeted non-agricultural land (Farmer 2009). Easements are an old land management tool with newfound popularity. However, there has not been an abundance of research geared toward private landowner motivation for participation in conservation easement programs (Farmer 2009). Therefore a model was developed to identify factors that may influence landowners' decision to place a conservation easement on their forest property.

Conservation is a concept that has determined the public agenda with regard to natural resource management for more than one hundred years (Cubbage et. al 1993) and with common threats to private forestland such as fragmentation, parcelization and development; the concept is more important now than ever. Conservation easements are a useful policy instrument that can help put that concept of conservation into practice. They have the ability to both preserve natural resources and keep working landscapes in production. Evaluating the motivations of NIPF landowners is vital to understanding the strengths and weaknesses of conservation easements as perceived by those in West Virginia, and it has far reaching implications since NIPF have majority ownership of timber resources nationally as well. Understanding NIPF landowner 
attributes and logic for considering enrollment can help to improve policies and programs. Enhancing easement initiatives in the broader sense is concurrent with the specific objectives of this study; which are to provide possible recommendations and useful information that may improve programs in West Virginia.

\subsection{Theoretical Framework}

The theoretical framework for this study is the Institutional Analysis and Development (IAD) framework. This is a mechanism used to organize research projects involving commonpool resources, as well as others, "where individuals find themselves in repetitive situations affected by a combination of factors derived from a physical world, a cultural world, and a set of rules" (Ostrom et al. 1994, p. 25). The IAD framework perpetuates the construction of theories about landowner decision processes, which take into account variation in land use activity and owner diversity (Koontz 2001). This paradigm was utilized for conceptualizing and constructing questions for data collection. A design necessary for researching an alternative, such as conservation easements, that accommodates a wide range of private sector individuals who own land for both different and multiple uses. Moreover, empirical studies are important in developing programs, by providing information on what influences landowner decisions, so that policy makers dealing with land management issues utilize their time and efforts more efficiently (Koontz 2001).

\subsection{Methodology}

\subsubsection{Data}

Mail survey data was collected in the fall of 2010 and spring of 2011 for this study. The population surveyed included NIPF landowners not participating in conservation easement 
programs. Surveys were sent to 2,100 individuals owning 20 or more acres of uncultivated lands in West Virginia. The 20-acre threshold was chosen to eliminate non-forestry uses (e.g., home sites).The landowner database used for this study was obtained from the State Tax Assessor's office.

Structuring development and disbursement of the survey instrument was based on “Internet, Mail, and Mixed-Mode Surveys: The Tailored Design Method” (Dillman et al. 2009). Three waves of mailing were delivered to encourage landowners to complete the survey and to gain the best possible response rate for the study. The first mailing of the combined cover letter and questionnaire was sent in November 2010, followed by a reminder letter in January of 2011 and concluded with another cover letter with the same questionnaire in February of 2011. There were no further mailings due to funding and time constraints.

Construction of the survey was also guided by the research of The Nature Conservancy (2010), Farmer (2009), Kaetzel et al. (2009), Fortney (2009), Ernst and Wallace (2008), Kabbi and Horwitz (2006), Ryan et al. (2003), Koontz (2001) and Bliss et al. (1997). The three categories identified in the survey were: 1) property information; 2) motivations and perceptions; and 3) demographics. Questions were developed in order to provide new data on what influences NIPF landowners to place an easement on their forestland. The purpose of utilizing results from previous studies in aiding formulation of the survey instrument was to gain further insight into landowner motivations for participation; which may provide possible recommendations to improve current initiatives and inform landowners. 


\subsubsection{Analysis}

Summary statistics for all the important variables in the survey were computed in Microsoft Excel 2010. In addition, t-tests and chi-square tests were conducted to compare landowners interested in participating in an easement program and those who are not. A regression model was also developed to examine factors affecting landowners' decision to place a forest conservation easement on their property.

\section{Model Hypothesis}

Landowners in West Virginia that are willing to consider enrolling their property in a forest conservation easement program have separate measurable attributes than NIPF landowners who are not willing to consider. Therefore, the null hypothesis is:

Ho: $\boldsymbol{\beta}=0$; There is no difference between NIPF landowners willing to consider and not willing to consider.

Ha: $\boldsymbol{\beta} \neq 0$; NIPF landowners willing to consider are not the same as those unwilling to consider.

\section{Model Specification}

This study looked at three categories of variables likely to influence NIPF landowner willingness to enroll in a forest conservation easement program. The categories were: 1) property information; 2) motivations and perceptions; and 3) demographics. The response variable was whether or not the individual was willing to consider participating in a forest conservation easement program; " 1 " if the respondent was willing to consider an easement and " 0 " if they were not willing. The empirical model is written as follows: 
$\mathrm{CNSDR}=\beta_{0}+\beta_{1}$ TIMUSE $+\beta_{2}$ ACRES $+\beta_{3} \mathrm{FOCOV}+\beta_{4} \mathrm{YRSACQ}+\beta_{5}$ TRNSFR $+\beta_{6}$

PROTAX $+\beta_{7}$ DISCIV $+\beta_{8}$ DISWIL $+\beta_{9}$ CONNEX $+\beta_{10}$ RIGHTS $+\beta_{11}$ VALCON $+\beta_{12}$

PERORG $+\beta_{13}$ DEVELP $+\beta_{14}$ SUBCTY $+\beta_{15}$ PERINC $+\beta_{16}$ INVEST $+\beta_{17}$ CONSRV $+\beta_{18}$

POLICY $+\beta_{19}$ AGE $+\beta_{20}$ EDLVL $+\beta_{21}$ INC $+\beta_{22}$ GENDER $+\beta_{23}$ EASTRN $+\varepsilon$

$\beta \mathrm{i}$ represents the model coefficients; while $\varepsilon$ is random or unexplained error. An explanation of the independent variables is provided in Table 4.1.

Table 4.1: Explanation of independent variables in the empirical model which evaluates what influences landowners to consider enrolling their property in a forest conservation easement program as reported by NIPF landowners in West Virginia, 2011.

\begin{tabular}{|c|c|}
\hline Variable & Explanation \\
\hline \multicolumn{2}{|c|}{ Property Information } \\
\hline TIMUSE & $\begin{array}{l}\text { Primary use of land. } 1=\text { timber production. } 0=\text { farmland, recreation, scenic } \\
\text { quality, residence or "other." }\end{array}$ \\
\hline ACRES & Amount of acres the respondent owns. \\
\hline FOCOV & The approximate percentage of forest cover on the respondent's property. \\
\hline YRSACQ & Number of years the respondent has owned the property. \\
\hline TRNSFR & $\begin{array}{l}\text { Whether the respondent was concerned with transferring property rights } \\
\text { to future generations. } 1=\text { yes. } 0=\text { no. }\end{array}$ \\
\hline PROTAX & $\begin{array}{l}\text { Whether the respondent was concerned with their ability to pay the current } \\
\text { property taxes. } 1=\text { yes. } 0=\text { no. }\end{array}$ \\
\hline DISCIV & Distance in miles the property is from the nearest town or city. \\
\hline DISWIL & $\begin{array}{l}\text { Distance in miles the property is from the nearest public lands (e.g., national } \\
\text { forests, national parks, state forests, state parks, etc.). }\end{array}$ \\
\hline \multicolumn{2}{|c|}{ Motivations and Perceptions } \\
\hline CONNEX & $\begin{array}{l}\text { Whether the respondent feels a personal connection to the property. Likert scale } \\
\text { with values } 1-4 \text {. }\end{array}$ \\
\hline RIGHTS & $\begin{array}{l}\text { How much the respondent was concerned with Conservation Easement (CE) } \\
\text { infringing on their private property rights. Likert scale with values 1-4. }\end{array}$ \\
\hline VALCON & $\begin{array}{l}\text { How valuable the respondents believed their property to be for conservation/how } \\
\text { important CE are to WV's landscape. Likert scale with values } 1-8 \text {. }\end{array}$ \\
\hline
\end{tabular}




\begin{tabular}{l|l}
\hline PERORG & $\begin{array}{l}\text { Respondent's perception of government and non-government organizational } \\
\text { trustworthiness. Likert scale with values 1-8. }\end{array}$ \\
\hline DEVELP & $\begin{array}{l}\text { Most valuable aspect of the property. 1 = development or "other." 0 = Timber, } \\
\text { agriculture, recreation, environment (endangered plants and animals) or scenery. }\end{array}$ \\
\hline SUBCTY & $\begin{array}{l}\text { Type of environment respondent was raised within. 1 = suburb or city. 0 = rural } \\
\text { forest, rural non-forest, mining town, farm or "other." }\end{array}$ \\
\hline PERINC & Approximate percentage of income respondent derives from the property. \\
\hline INVEST & $\begin{array}{l}\text { Whether the respondent considers their property to be a monetary investment. } \\
1=\text { yes. 0 = no. }\end{array}$ \\
\hline CONSRV & $\begin{array}{l}\text { Respondent's perception of the importance of conservation and preservation topics } \\
\text { (e.g., conservation, preservation, wildlife habitat, public recreation or education, } \\
\text { historic preservation and scenic enjoyment). Likert scale with values 1-24. }\end{array}$ \\
\hline POLICY & $\begin{array}{l}\text { Respondent's perception of environmental policies in the US. Likert scale with } \\
\text { values 1-4. }\end{array}$ \\
\hline Demographics & \multicolumn{2}{|l}{} \\
\hline AGE & \begin{tabular}{l} 
Age of respondent in years. \\
\hline EDLVL
\end{tabular} \\
\hline INC & $\begin{array}{l}\text { Level of education received by the respondent. 1 = associate degree or further. } \\
0=\text { GED or high school. }\end{array}$ \\
\hline GENDER & $\begin{array}{l}\text { Approximate annual income of respondent in dollars. } \\
\text { Morgan, Berkeley and Jefferson Counties. 0 = otherwise. }\end{array}$ \\
\hline
\end{tabular}

There are eight variables that factor the property information section of the questionnaire into the model (TIMUSE, ACRES, FOCOV, YRSACQ, TRNSFR, PROTAX, DISCIV and DISWIL). Importance of timber production and amount of acres has been found to be positively correlated with conservation assistance programs (Kaetzel et al. 2009). Therefore, it is hypothesized that TIMUSE and ACRES will have positive coefficients in the model. In addition, length of ownership and issues regarding tax savings has shown to have negative and positive associations, respectively, with NIPF participation in the WV Managed Timberland Forest Tax 
Incentive Program (Fortney et al. 2011). With this in mind, the expectation for the similar variables in this study is as follows: YRSACQ as negative and PROTAX as positive.

Property that abuts public land is considered by Wallace et al. (2008) to be a buffer zone. DISWIL is then expected to have a negative sign in the model. Conservation easements are widely used to prevent development, and so DISCIV is likely to have a negative coefficient as well. Ernst and Wallace (2008) looked at family heritage in their study concerning private land conservation. Here the predictor TRNSFR is hypothesized to be positively related to participation. There are few, if any, empirical models that evaluate variables associated with private landowners and conservation easements on forested landscapes (Farmer 2008). Therefore, the forest aspect FOCOV has been included in the model and is expected to be positively associated with enrollment to a forest easement program.

Ten variables representing the motivations and perceptions of private forest landowner's in West Virginia are included in the model (CONNEX, RIGHTS, VALCON, PERORG, DEVELP, SUBCTY, PERINC, INVEST, CONSRV and POLICY). Farmer (2009) found personal connection to the land to be an influential motivator for easement participation. It is then hypothesized that CONNEX will have a positive coefficient within this model. Kabii and Horwitz (2006) published a framework about what influences landowners to uptake permanent covenants, which included "their appreciations of, and attitudes to, notions of property rights" ( $\mathrm{p}$. 12). RIGHTS is then posited to have a negative relationship with enrollment; an understandable belief that the less one feels the conservation easement will infringe on his/her private property rights then the more likely they will be to consider participation. Kaetzel et al. (2009) showed information from government agencies to be positive and significant. Here PERORG includes 
the respondent's rating of government and non-governmental organizations and is expected to have a coefficient above zero as well.

VALCON is likely to have a positive sign because it is intuitive to assume that if landowners believe their property has conservation value and conservation easements to be important to West Virginia's landscape, then they may be willing to consider enrollment. DEVELP is expected to be negative; a probable assumption being landowners who believe development or "other" to be the most valuable aspect of their property would be less likely to ease the land. Previous studies concerning conservation easements have questioned the respondent about the environment in which they were raised (Farmer 2009). SUBCTY is expected to have a positive sign, hypothesizing that individuals raised in such an environment may have more access and exposure to information about conservation alternatives. Results from Kaeztel et al. (2006) suggest that landowner dependence on income from the property should be examined in future research. Therefore, PERINC is included in the model. It is expected to have a positive coefficient; the assumption being that landowners more dependent on their property for income would be more likely to protect the land and possibly benefit from the financial incentives accompanied by conservation easements.

Koontz (2001) argues that broad sweeping economic models utilized to describe property sale prices and land use patterns are based on owner motivations being monetary, but a more helpful approach to individual decision making, particularly when multiple land uses are involved, should account for nonmonetary benefits. Therefore, INVEST is hypothesized to be negative. Conversely, it is expected that CONSRV will be positive in that landowners that believe conservation and preservation topics to be relatively important may be more likely to place a conservation easement on their forestland. This is consistent with Ernst and Wallace 
(2008) discussion point that natural resource preservation and public benefit are more influential than other factors; such as estate matters and monetary issues. Finally, POLICY is believed to return positive; a plausible assumption being individuals who believe environmental policies in the United States are effective then the more likely they are to utilize one.

There are five predictors in the model representing demographics (AGE, EDLVL, INC, GENDER and EASTRN). Age has been utilized in previous research studies (Fortney et al. 2011; Joshi and Arano 2009) where the variable was found to have negative associations with participation in West Virginia's Managed Timberland program and forest management decisions in general. Therefore AGE is hypothesized to be negative here as well. EDLVL and INC are expected to have a positive association with enrollment. Both hypotheses agree with Fortney et al. (2011) that higher education and more income positively influence West Virginia NIPF management decisions toward participation in the Managed Timberland Program.

Few studies have investigated the effect of gender on participation in conservation assistance programs; causal factors for varying results could be the low percentage of female owners or mere landowner diversity (Kaetzel et al 2009). Yet, Gan et al. (2005) found women more likely to participate in the USDA's Conservation Reserve Program (CRP). Therefore, GENDER is expected to be negative in the model. As referenced often in this study, there is a lot of development present in the eastern panhandle of West Virginia (American Farmland Trust 2009). This in mind, EASTRN is expected to have a positive coefficient.

\section{Model Estimation}

The response variable (CNSDR) is binary, willing to consider a forest conservation easement program (1), not willing to consider (0). Due to the binomial distribution, a linear 
estimator is not appropriate. Therefore the model will be calculated using logistic regression. The concept of the link function is essential to generalized linear models because it connects the mean of the dependent variable to the larger caste of models (Faraway 2006). Logistic regression is considered by Agresti (2002) to be the most important model for categorical response data. It takes the form:

$$
\begin{aligned}
& \operatorname{Pr}(y=1 \mid x)=[\exp (\beta x)] /[1+\exp (\beta x)] \\
& \text { Where: } \\
& y=\text { the probability that a respondent is willing to consider enrollment given } \mathrm{x} ; \\
& \mathrm{x}=\text { the independent variables; and } \\
& \beta=\text { the model coefficients, }
\end{aligned}
$$

The statistical software $\mathrm{R}$ was utilized to estimate the model parameters ( $\mathrm{R}$ version 2010).

\subsection{Results}

\subsubsection{Survey Response}

From the 2,100 possible respondents; 697 were returned undeliverable; the landowner was deceased, had recently sold the property or was not a forestland owner. About 592 usable questionnaires were returned and constituted the database for this analysis. The final survey response rate was $42.19 \%$.

The response variable for this study is whether or not the NIPF respondent was willing to consider enrolling their property in a forest conservation easement program. Most of the responding landowners $(66.6 \%)$ were unwilling to participate in an easement program. The 
remaining individuals (33.4\%) were willing to consider easing their woodland property.

Respondent's willingness to consider a woodland easement program is illustrated in Figure 4.1.

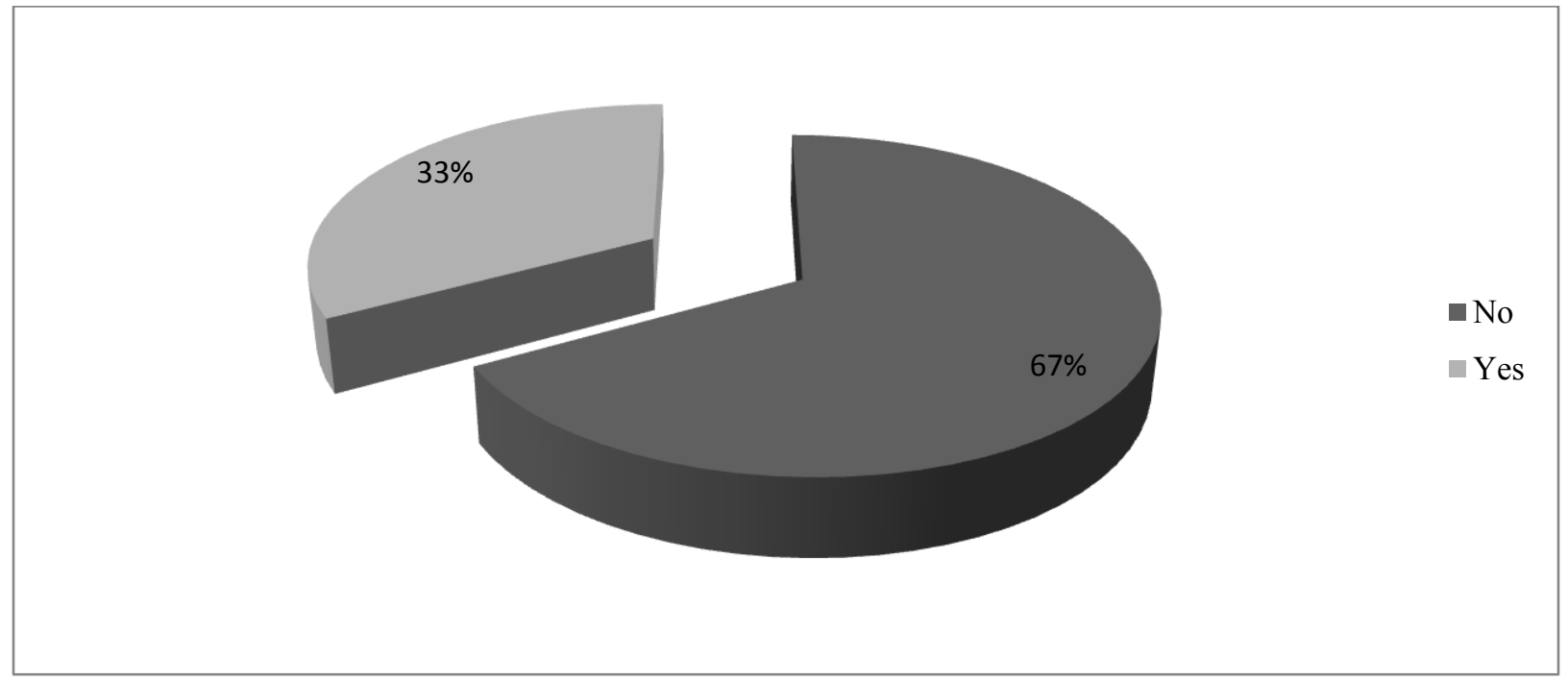

Figure 4.1: Would you consider enrolling your property in a forest conservation easement program? As reported by NIPF landowners in West Virginia, $2011(\mathrm{n}=488)$.

\subsubsection{Property Information}

The county in which the woodland property is located was divided into six regions for this analysis. The areas are entitled the Northern Panhandle region, the Little Kanawha region, the Wes-Mon-Ty region, the Eastern Panhandle region, the Great Kanawha region and the Mountain region. West Virginia's Resource Conservation and Development Council's (RC\&D) regional map was utilized for delineation of boundaries (USDA NRCS 2011). The Resource Conservation and Development Area map is depicted in Figure 4.2. 


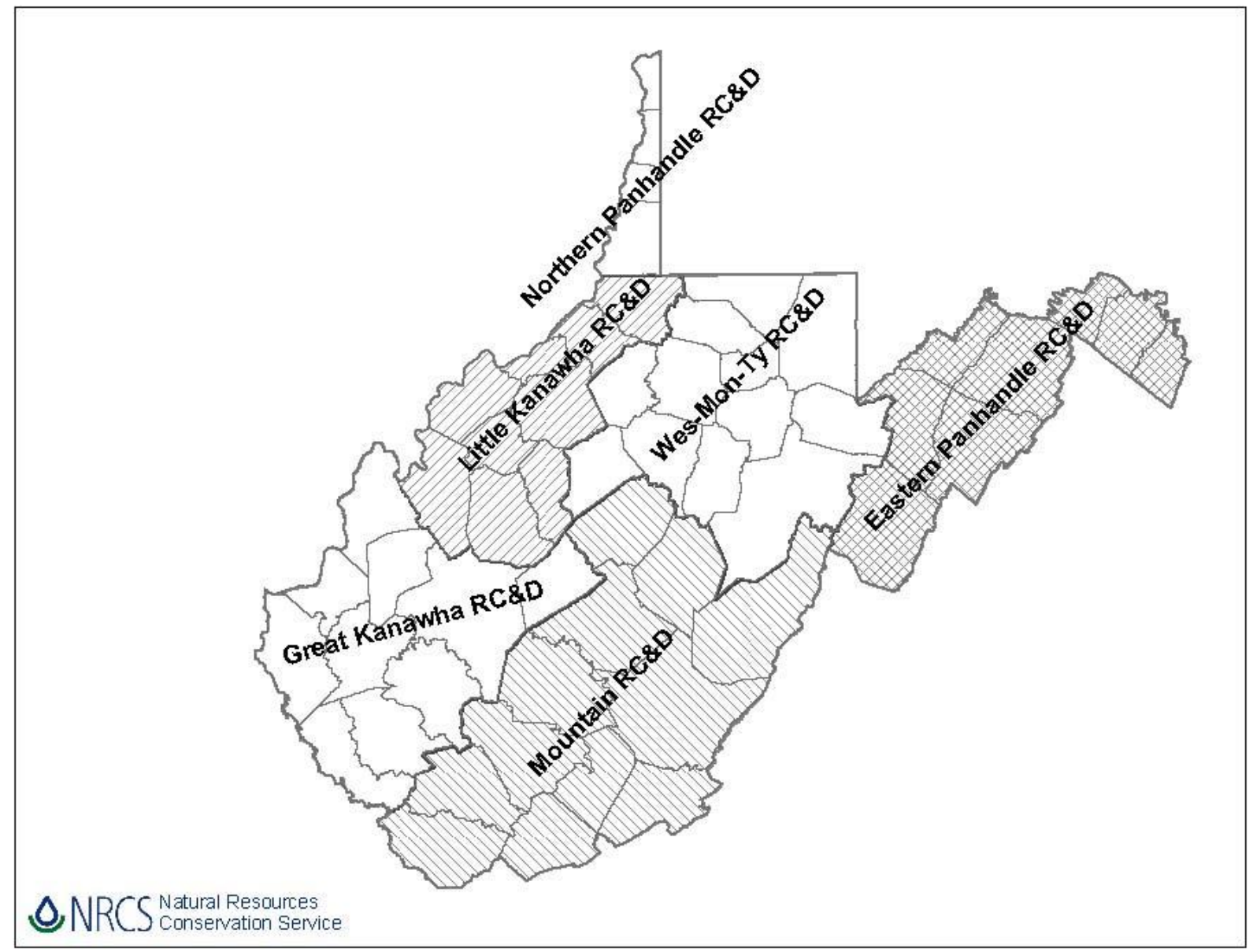

Figure 4.2: Resource Conservation and Development Areas. West Virginia, 2011.

Landowners with property located in the Eastern Panhandle (Figure 4.3) appear more likely to consider an easement program. The chi-square test was significant at .10 level between region of woodland location and whether or not the NIPF landowner would consider enrollment in a forestland conservation easement program. There were 463 total observations in this graphic $(n=463)$. 


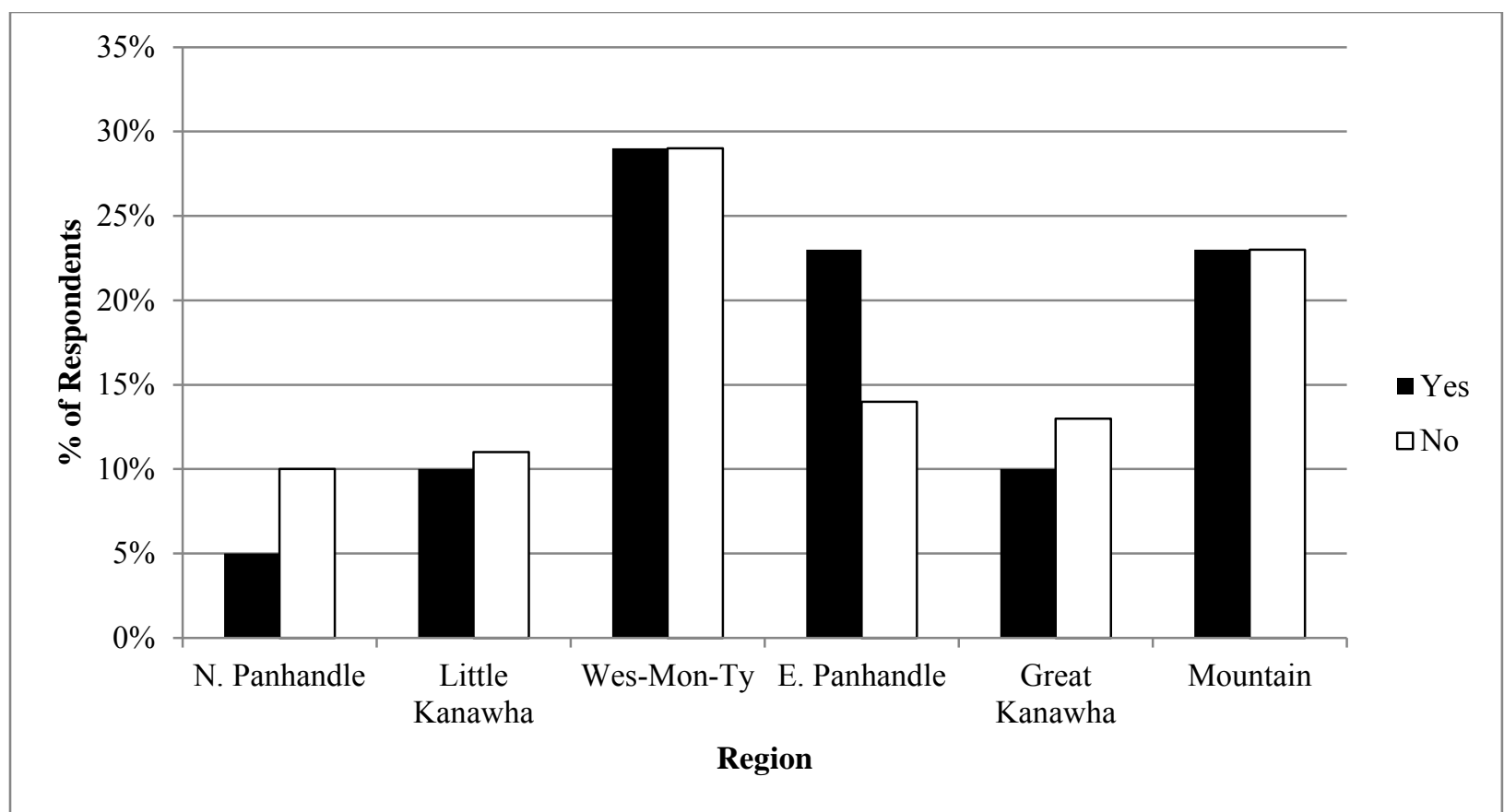

Figure 4.3: Location of woodland property as reported by NIPF landowners in West Virginia, $2011(\mathrm{n}=463)$.

Individuals with timber, recreation, scenic quality and "other" (e.g., hunting, wildlife, natural area) listed as their primary use of land, rather than residence and farmland, appear to be somewhat more likely to consider a woodland easement program (Figure 4.4). The chi-square difference test between all primary uses and willing to consider a forestland conservation easement program was significant at the .01 level for this distribution. This indicates there might be an influential relationship between all primary uses of the land and whether or not the landowner will consider placing the property under easement. 


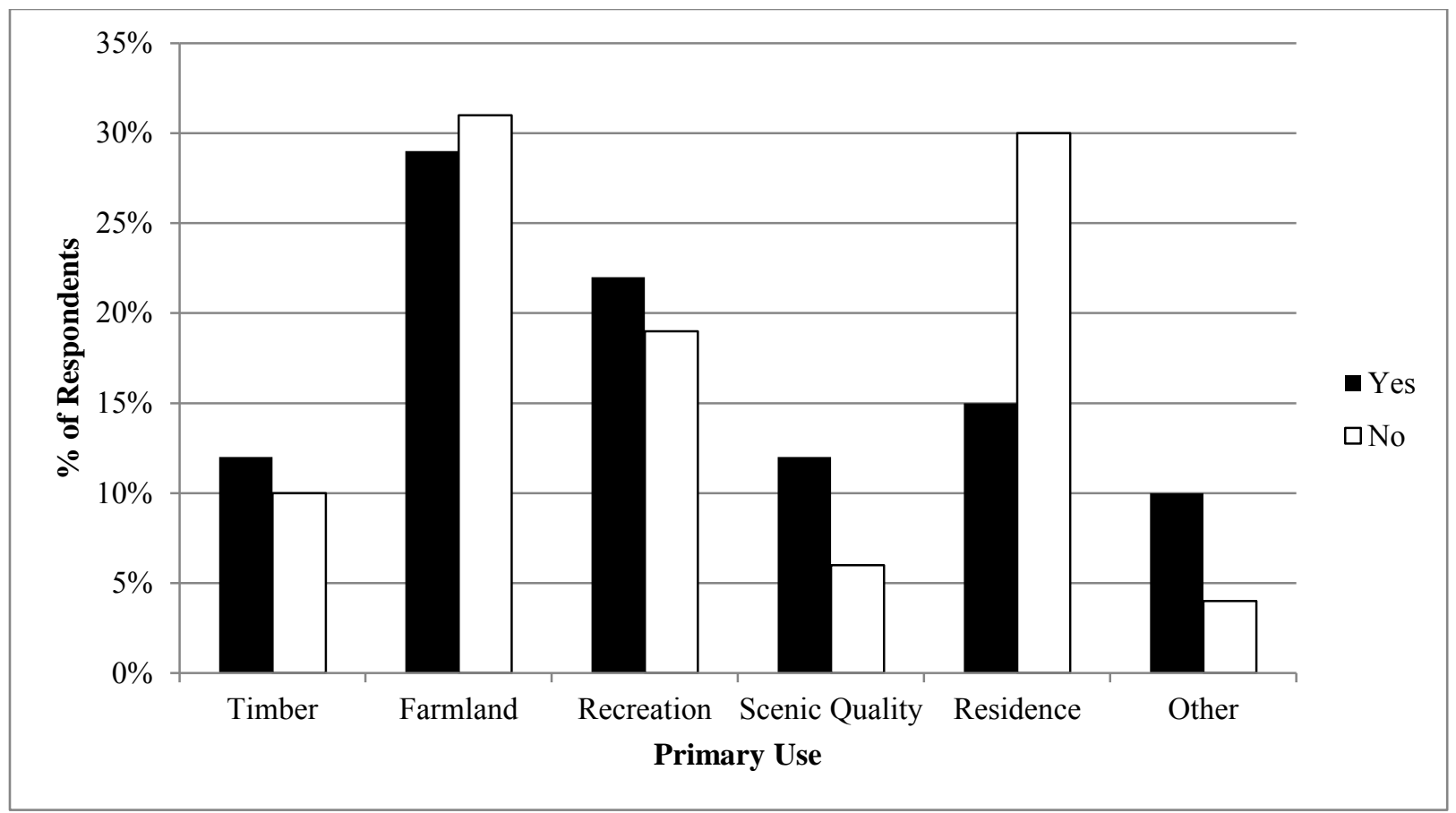

Figure 4.4: Primary use of land as reported by NIPF landowners in West Virginia, $2011(\mathrm{n}=435)$.

Respondents that had more family heritage with the property (e.g., second, third or fourth generational landowners) may be more willing to participate in a forestland easement program (Figure 4.5). This chi-square test between generation of the landowner and whether or not they would be willing to enroll in an easement program was significant at the .01 level. 


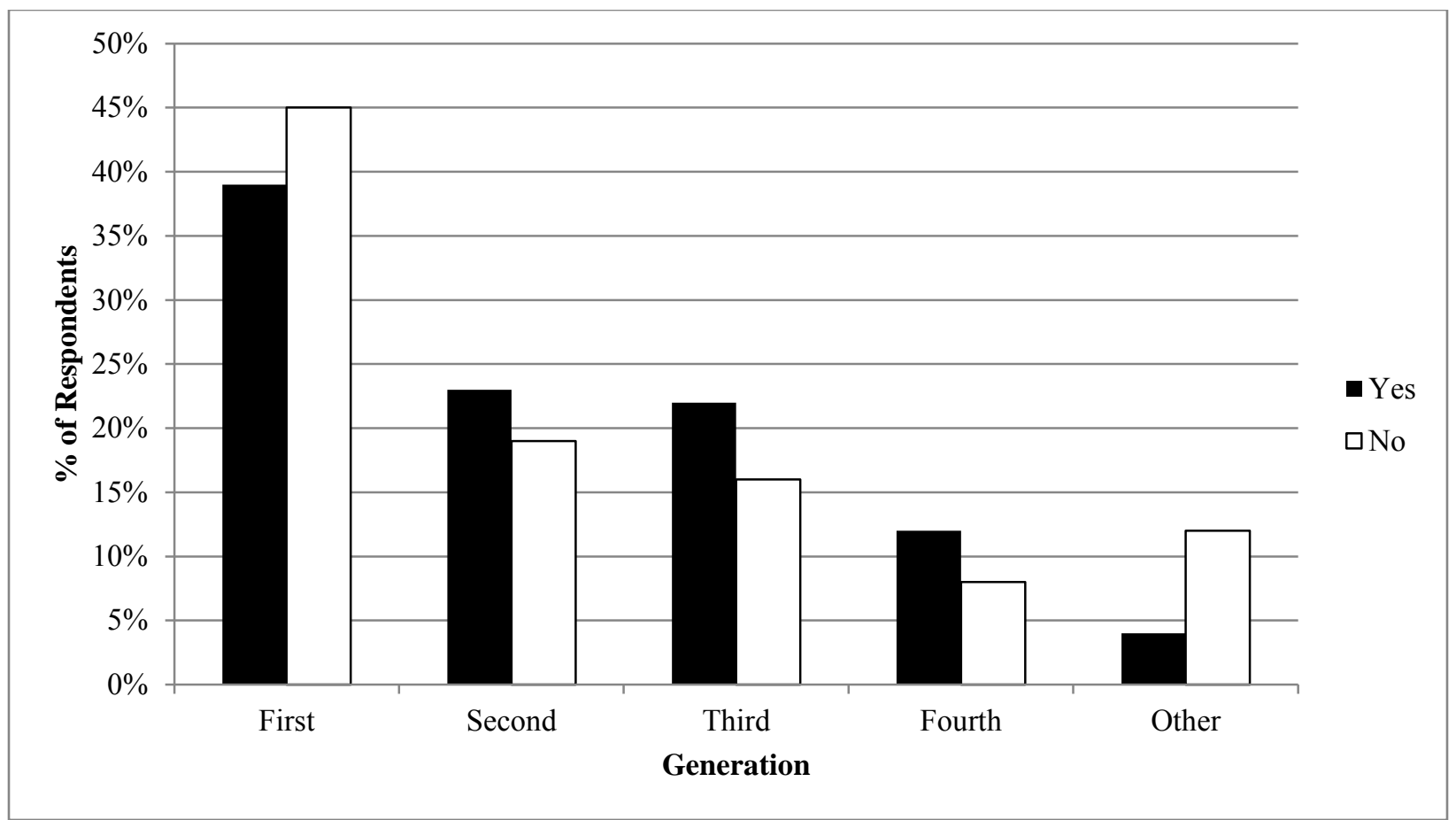

Figure 4.5: Generation of landowner as reported by NIPF landowners in West Virginia, 2011 $(n=477)$.

Individuals concerned with transferring their property rights to future generations appear to have a higher likelihood of enrollment in a conservation easement (Figure 4.6). This chisquare distribution difference test between NIPF landowner concern with transferring property rights and whether or not the respondent was willing to consider participating in a woodland easement program was significant at the .01 level. 


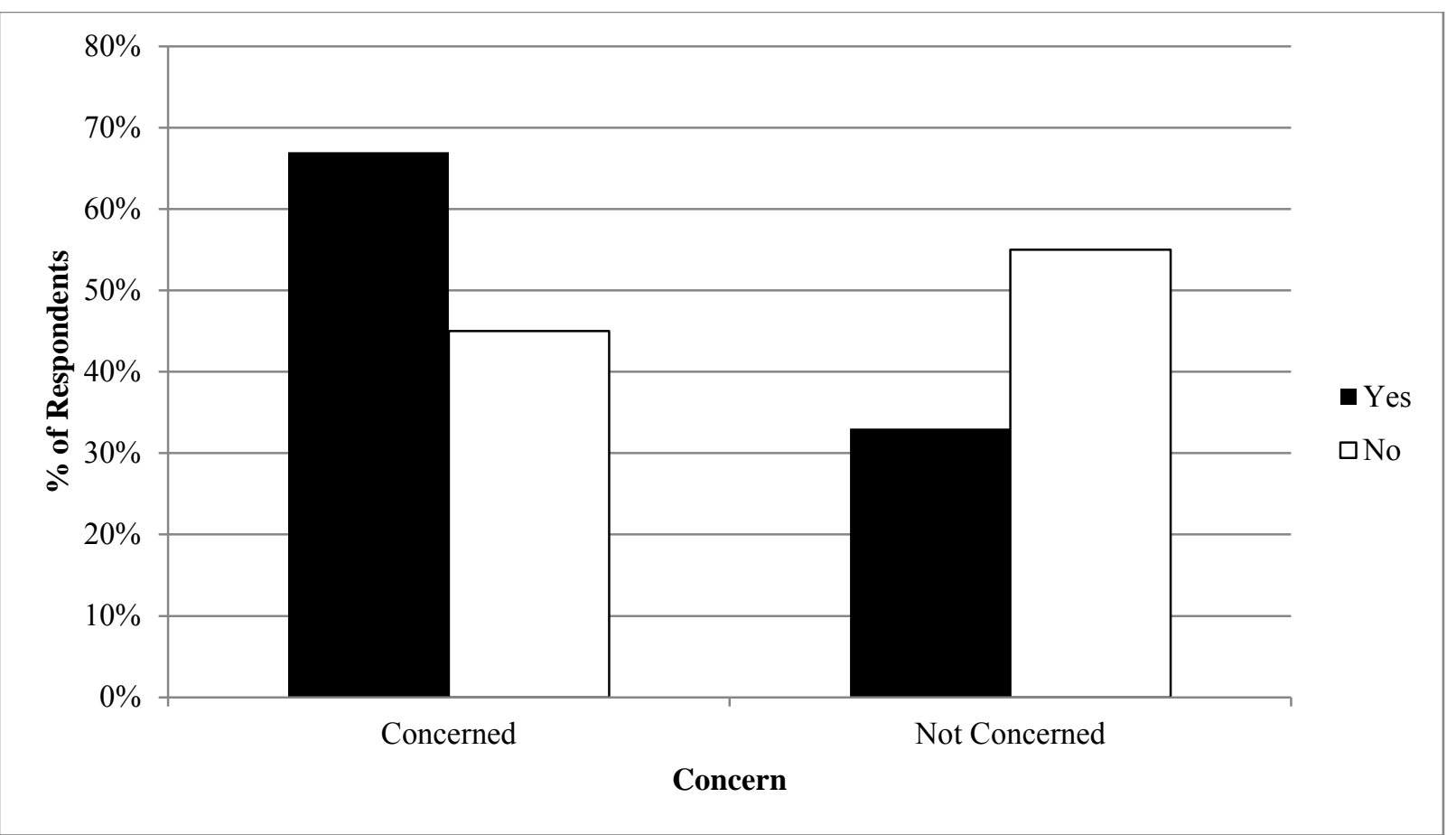

Figure 4.6: Landowner concern about transferring property rights to future generations as reported by NIPF landowners in West Virginia, $2011(n=477)$.

The individuals anxious about paying property taxes were more likely to consider participating in a program (Figure 4.7). The chi-square difference test between the landowner's concern regarding their ability to pay the current property taxes and whether or not they would consider a forestland conservation easement program was significant at the .10 level. 


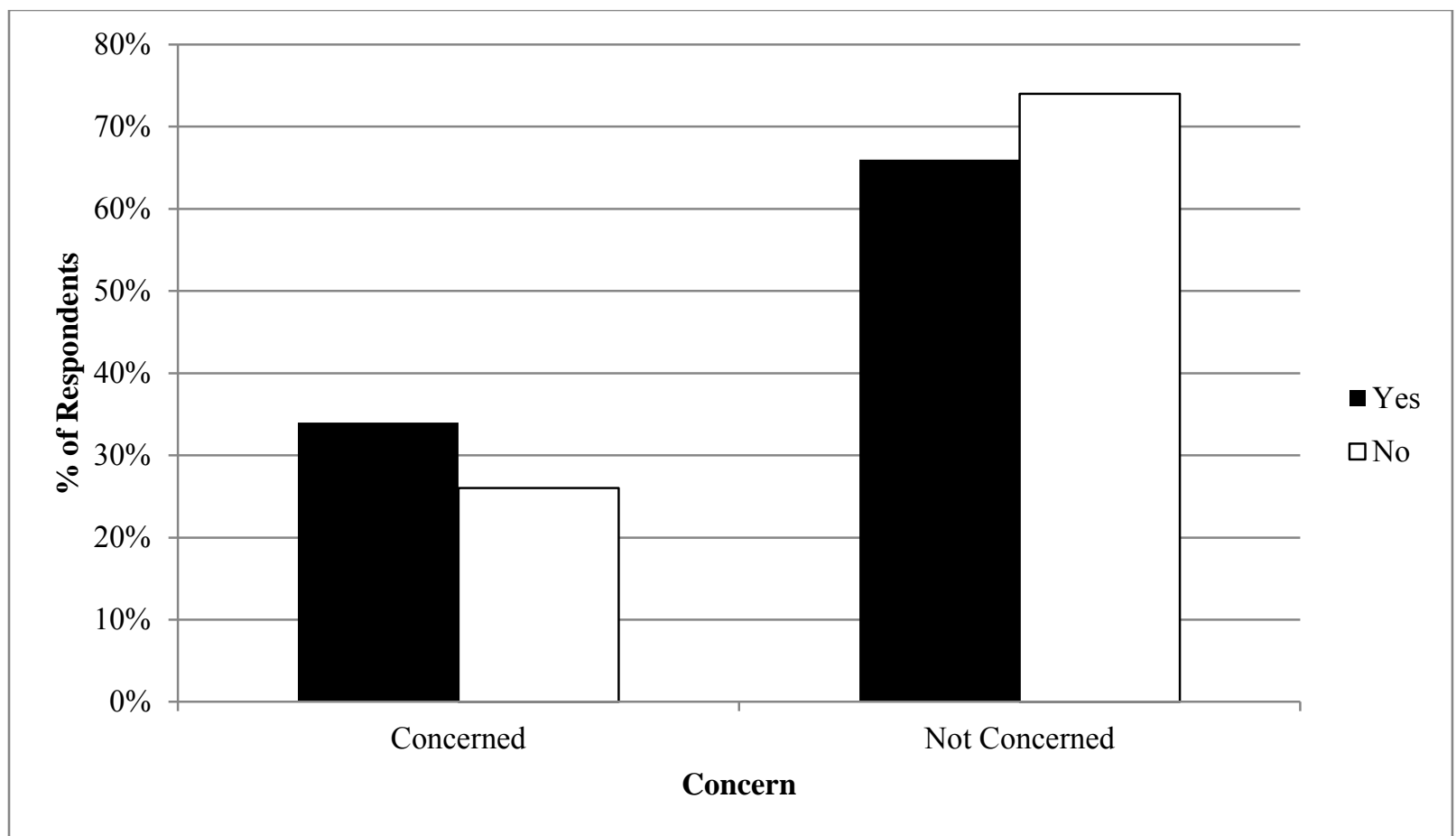

Figure 4.7: Landowner concern with their ability to pay the current property taxes as reported by NIPF landowners in West Virginia, $2011(\mathrm{n}=475)$.

Whether or not the individual was raised on or near the property they owned had a pvalue of 0.232 , and therefore was not statistically significant (Figure 4.8). 


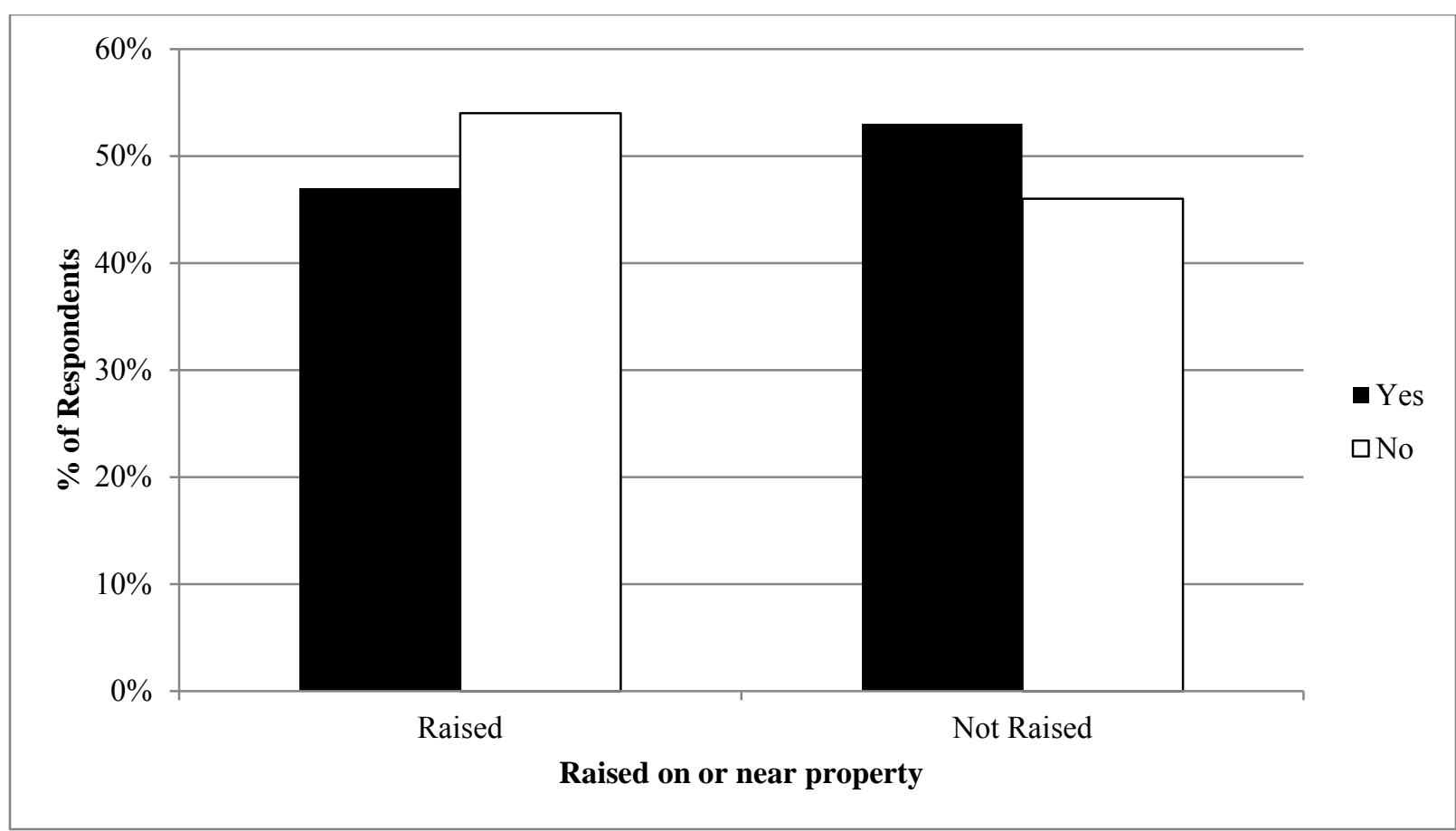

Figure 4.8: Whether the landowner was raised on or near the property they own as reported by NIPF landowners in West Virginia, $2011(\mathrm{n}=483)$.

Descriptive means are listed in Table 4.2 for the continuous variables in the property information section of the questionnaire. Landowners were asked how many acres they owned, what percentage of forest cover was on their property, how long they have owned the parcel, how far the land is from the nearest town or city and how far the land is from the nearest public lands (e.g., state or national park). T-tests were run to see if there were any significant differences between the means for the respondents who answered they would consider participating in an easement program and respondents who would not. Amount of acres owned was significant at the .10 level and the individuals likely to consider enrollment owned more land by an average of 92.13 acres. 
Table 4.2: Property statistics as reported by NIPF landowners in West Virginia, 2011.

\begin{tabular}{|l|c|c|}
\hline \multirow{2}{*}{ Description } & \multicolumn{2}{c|}{ Mean } \\
\cline { 2 - 3 } & Yes & No \\
\hline Acres owned* & 222.99 & 130.86 \\
\hline Percent forest cover & 66.15 & 64.3 \\
\hline Length of ownership (years) & 26.29 & 26.73 \\
\hline Distance from nearest town/city (miles) & 10.25 & 9.08 \\
\hline Distance from nearest public lands (miles) & 16.04 & 17.03 \\
\hline
\end{tabular}

* T-Test significant at the .10 level.

\subsubsection{Motivations and Perceptions}

Each landowner was asked what they considered to be the most valuable aspect of their property (Figure 4.9). Individuals who perceived recreation, environment (e.g., endangered plants and animals) and scenery to be most valuable may be more willing to consider participation. The chi-square distribution difference test between all valuable aspects and the respondent's willingness to consider enrollment was significant at the .05 level. 


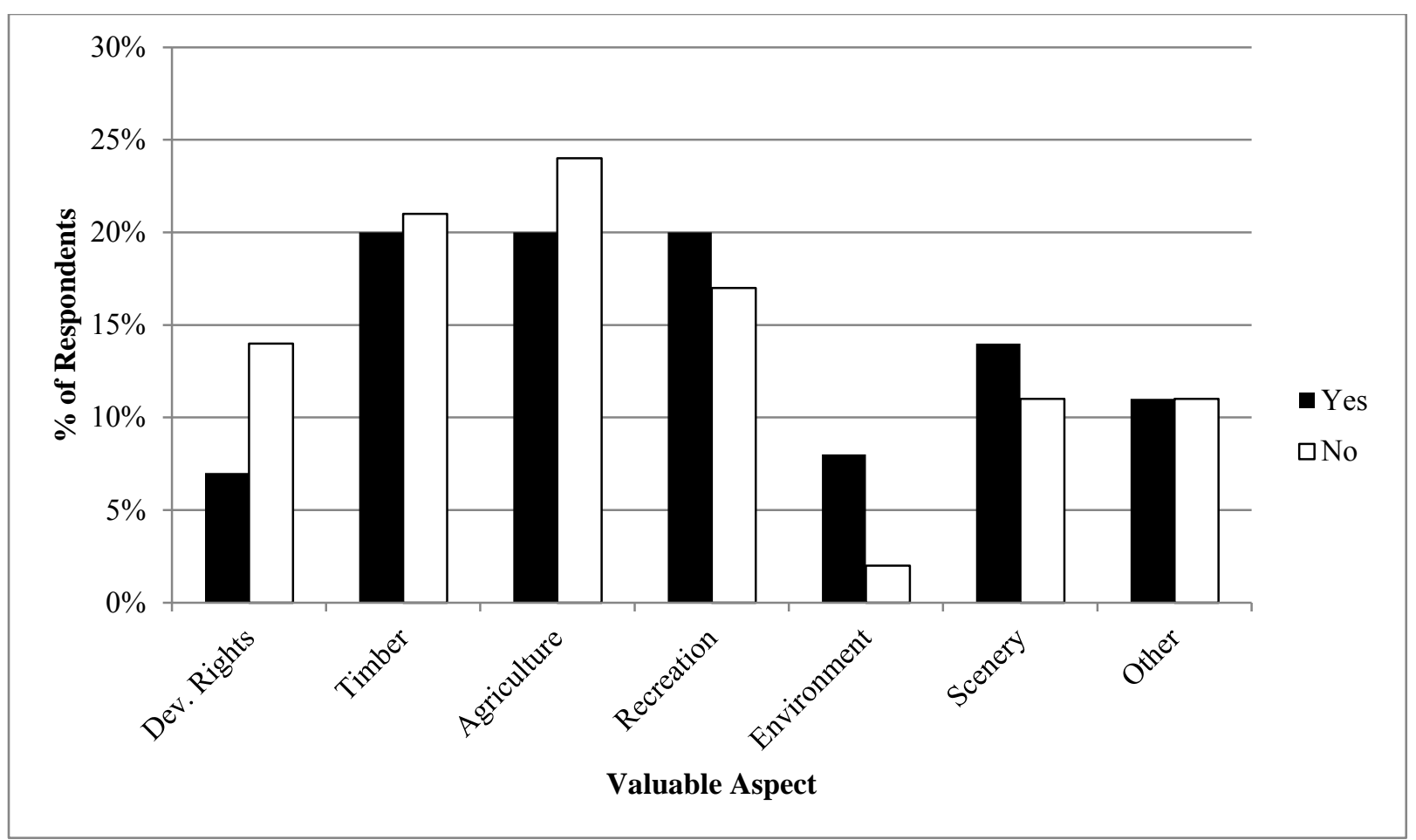

Figure 4.9: Landowner perception of the most valuable aspect of their property as reported by NIPF landowners in West Virginia, $2011(n=441)$.

The type of environment the landowner grew up within had a p-value of 0.232 , and therefore was not significant (Figure 4.10) while the current living environment for West Virginia woodland owners was significant at the .10 level (Figure 4.11). Individuals living in a rural non-forest, suburb, city or "other" (e.g., small town, country, orchard) category were positively inclined toward participation. 


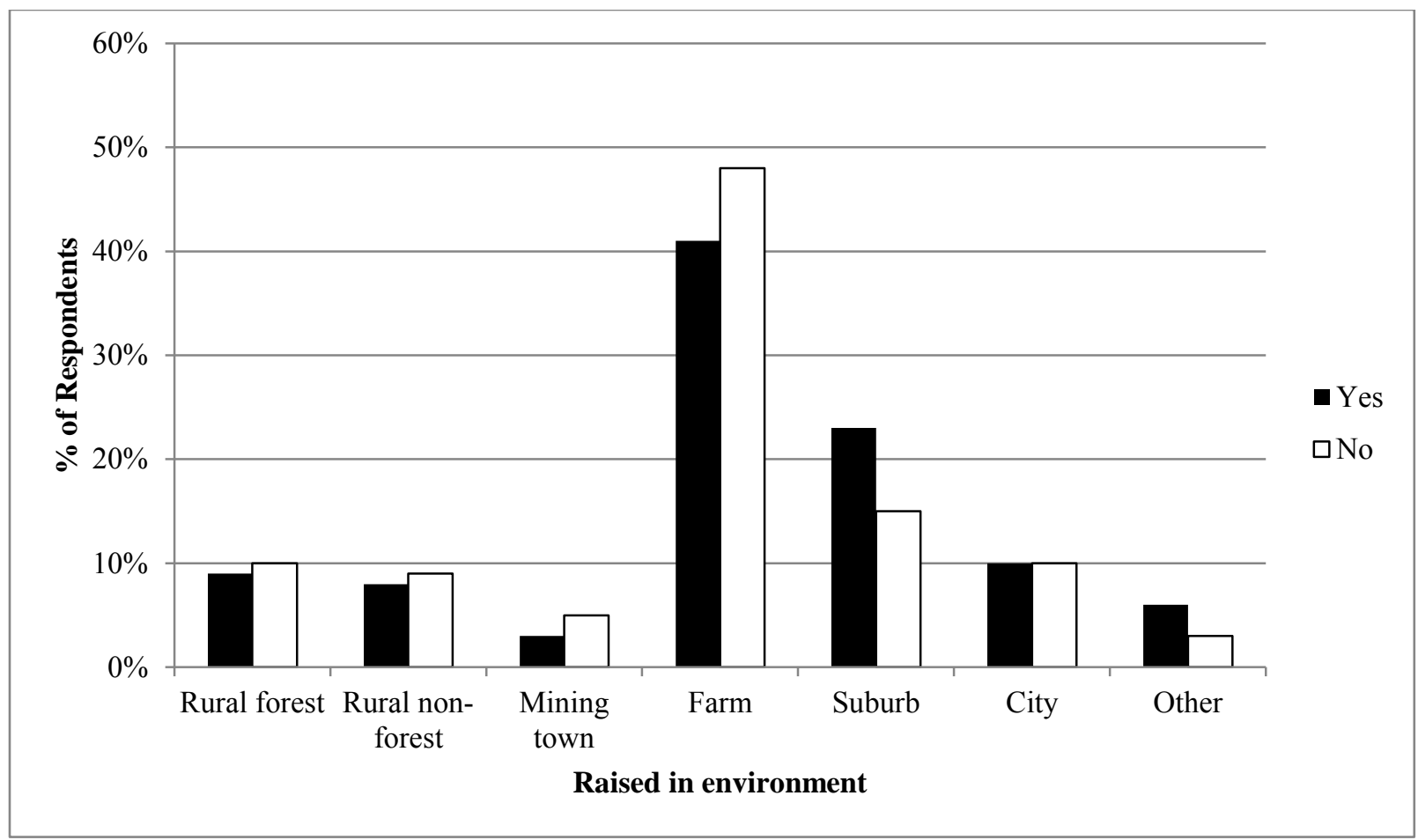

Figure 4.10: Type of environment respondents were raised within as reported by NIPF landowners in West Virginia, $2011(\mathrm{n}=477)$.

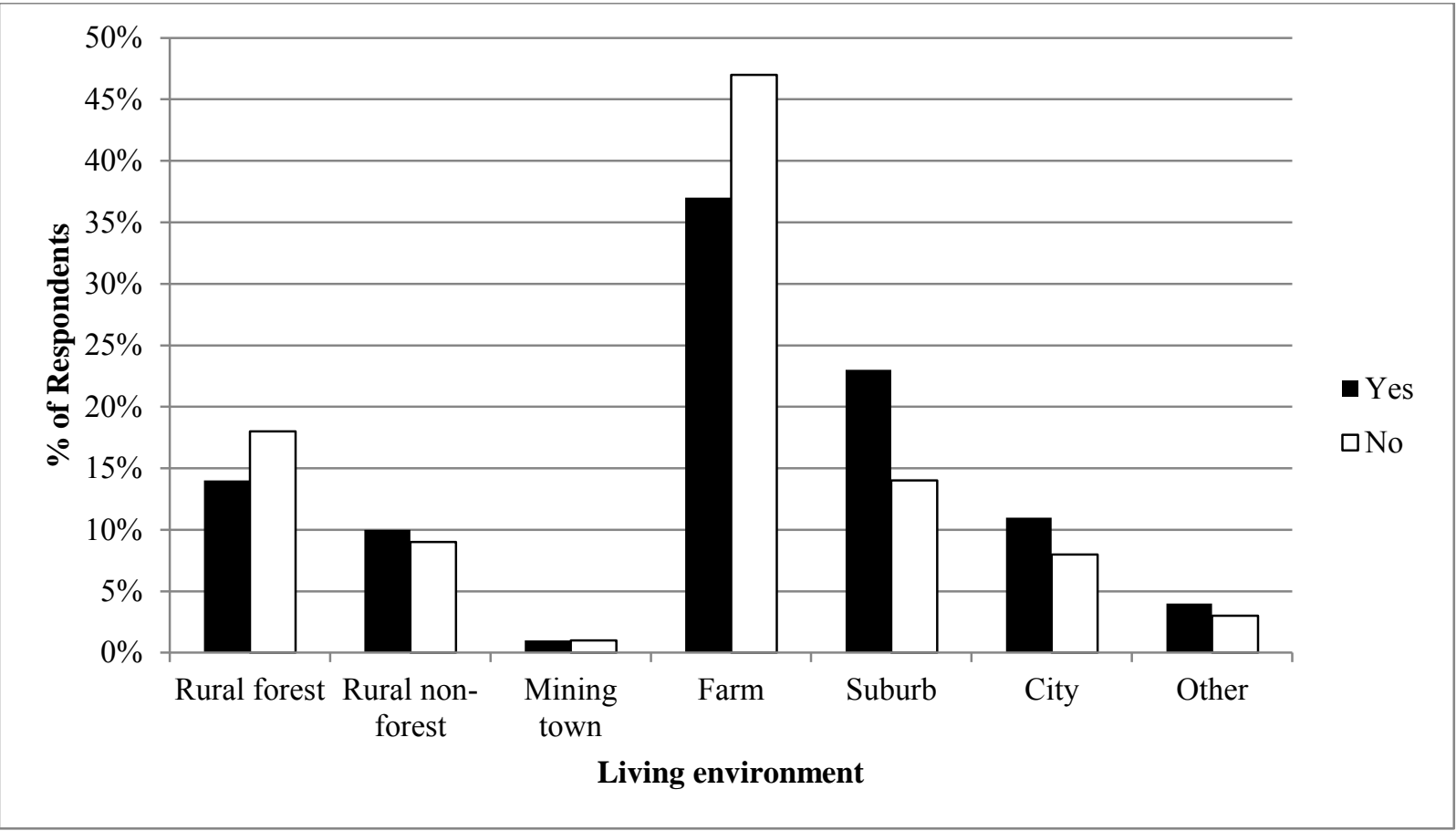

Figure 4.11: Current living environment as reported by NIPF landowners in West Virginia, 2011 $(n=476)$. 
The chi-square test between whether the respondents believed their property to be an investment and whether they would consider placing a conservation easement on the property (Figure 4.12) was not significant (P-value 0.198).

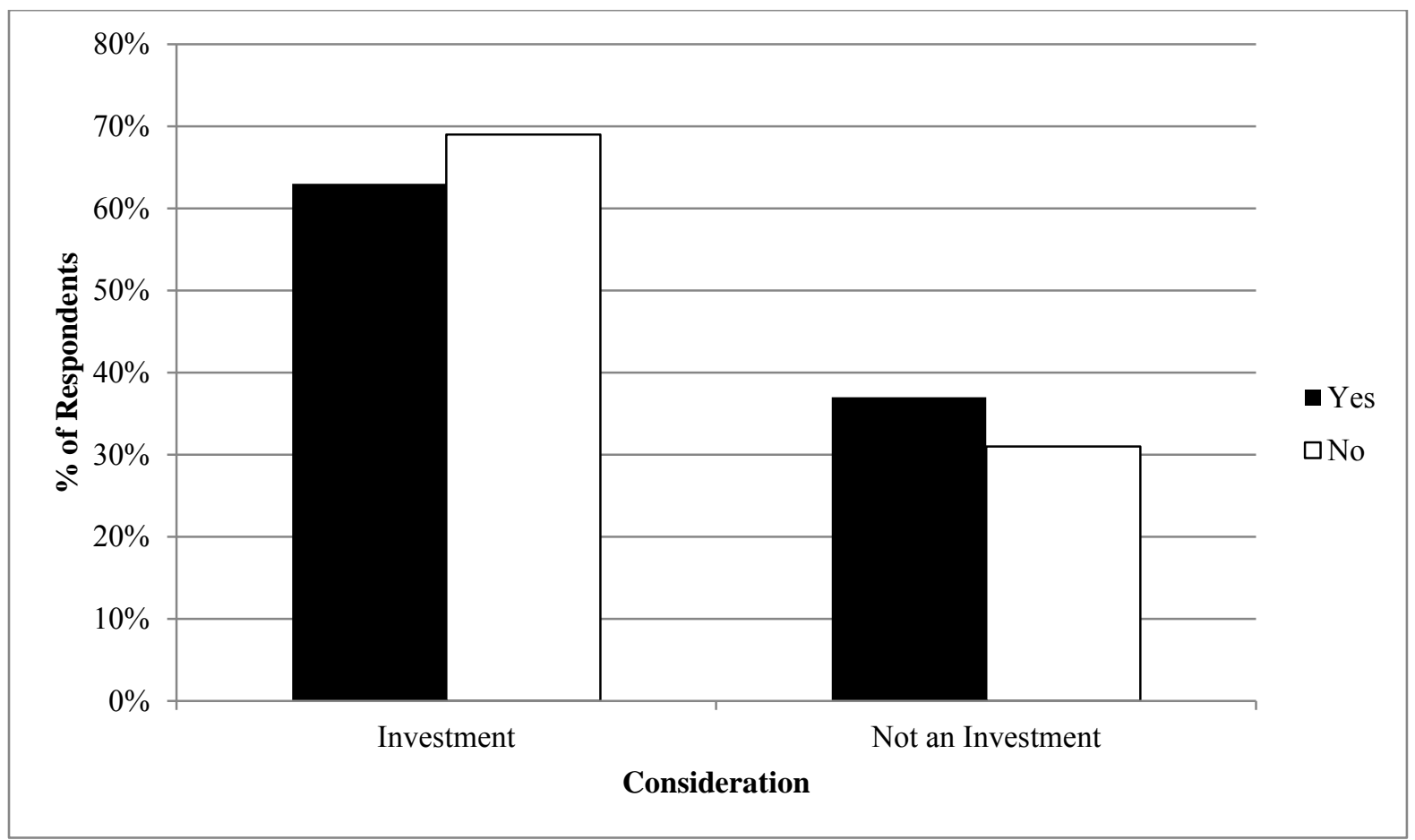

Figure 4.12: Whether respondents consider their property to be a monetary investment as reported by NIPF landowners in West Virginia, $2011(\mathrm{n}=470)$.

The averages concerning approximate percentage of income derived from the land are displayed in Table 4.3. NIPF that depend on their property for a larger percentage of their salary were more likely to consider participating in a program. The t-test for difference between sample means was significant at the .05 level. 
Table 4.3: Percentage of income derived from the land as reported by NIPF landowners in West Virginia, 2011.

\begin{tabular}{|c|c|c|}
\hline \multirow{2}{*}{ Description } & \multicolumn{2}{|c|}{ Mean } \\
\cline { 2 - 3 } & Yes & No \\
\hline Percent of income derived from the land** & $9.84 \%$ & $5.83 \%$ \\
\hline
\end{tabular}

** T-Test significant at the .05 level.

The landowners received a series of questions that are, for the purpose of this study, considered potential motivations (Table 4.4). Results showed respondents that have a strong personal connection to their property are more likely to participate. In fact, the t-test for the "yes" to "no" mean comparison concerning personal connection was statistically significant at the .01 level. In addition, NIPF who feel land ownership in West Virginia provides them with a sense of place lean toward enrollment; showing significance at the .10 level. Individuals that think being active within their community is relatively important and have more development pressure on or around their land show better likelihood to participate; results of these t-tests were significant at the .01 and .05 levels respectively. The test regarding landowner perception of national environmental policy effectiveness showed no significant difference (T-test 0.205).

Table 4.4: Potential motivations for enrollment as reported by NIPF landowners in West Virginia, 2011.

\begin{tabular}{|l|c|c|}
\hline \multirow{2}{*}{\multicolumn{1}{c|}{ Description }} & \multicolumn{2}{c|}{ Mean Likert Score } \\
\cline { 2 - 3 } & Yes & No \\
\cline { 2 - 3 } & 3.71 & 3.51 \\
\hline Personal connection to land*** & 3.73 & 3.63 \\
\hline Land in WV provides sense of place* & 3.18 & 2.85 \\
\hline Owner perception of civic responsibility*** & 2.45 & 2.27 \\
\hline Development pressure** & 2.30 & 2.36 \\
\hline Perception of environmental policies & & \\
\hline
\end{tabular}

* T-Test significant at the .10 level.

** T-Test significant at the .05 level.

*** $\mathrm{T}$-Test significant at the .01 level. 
In addition to potential motivations, landowners were asked about what the researchers perceived to be potential barriers (Table 4.5). NIPF that had a better understanding about conservation easements were more willing to enroll, the t-test being significant at the .05 level. Landowners that had been exposed to more information about conservation easements or were less worried about easement restrictions infringing on their property rights showed greater likelihood to participate; each of the tests were significant at the .01 level. Finally, the more one felt their property had conservation value and that easements were important to the landscape of West Virginia responded positively toward enrollment; both mean comparisons showing significance at the .01 level.

Table 4.5: Potential barriers for enrollment as reported by NIPF landowners in West Virginia, 2011.

\begin{tabular}{|c|c|c|}
\hline \multirow[b]{2}{*}{ Description } & \multicolumn{2}{|c|}{$\begin{array}{c}\text { Mean Likert Score } \\
(1 \text { to } 4 ; \text { where } 1=\text { none and } 4=\text { a lot })\end{array}$} \\
\hline & Yes & No \\
\hline Knowledge of CE** & 2.16 & 1.98 \\
\hline Exposure to info about $\mathrm{CE}^{* * *}$ & 1.93 & 1.67 \\
\hline Concern about $\mathrm{CE}$ infringing on $\mathrm{PPR}^{* * *}$ & 2.70 & 3.22 \\
\hline Value of property for conservation*** & 3.35 & 2.71 \\
\hline Importance of CE to WV's landscape*** & 3.46 & 2.60 \\
\hline
\end{tabular}

** T-Test significant at the .05 level.

*** T-Test significant at the .01 level.

Landowner perceptions of conservation and preservation topics appear to have an effect on whether or not they will consider participating in a woodland conservation easement program (Table 4.6). In fact, each t-test within this grouping was statistically significant at the .01 level. Respondents were asked about the importance of conservation (managed landscapes) and preservation (unaltered landscapes); results of the analysis showed individuals who felt these topics were more important were more likely to consider an easement. Furthermore, the respondents who felt protecting wildlife habitats, historic structures and scenery was a necessity 
were more probable to enroll. Maintaining venues for public recreation or education presented the same results; NIPF who thought the issue meaningful were more likely to participate in a conservation easement program.

Table 4.6: Importance of conservation and preservation topics as reported by NIPF landowners in West Virginia, 2011.

\begin{tabular}{|c|c|c|}
\hline \multirow[b]{2}{*}{ Description } & \multicolumn{2}{|c|}{$\begin{array}{c}\text { Mean Likert Score } \\
(1 \text { to } 4 \text {; where } 1=\text { none and } 4=\mathrm{a} \text { lot })\end{array}$} \\
\hline & Yes & No \\
\hline Land conservation $* * *$ & 3.29 & 2.80 \\
\hline Land preservation $* * *$ & 3.38 & 2.85 \\
\hline Wildlife habitat*** & 3.56 & 3.36 \\
\hline Public recreation or education $* * *$ & 2.92 & 2.54 \\
\hline Historic preservation $* * *$ & 3.20 & 2.71 \\
\hline Scenic enjoyment $* * *$ & 3.45 & 3.13 \\
\hline
\end{tabular}

*** T-Test significant at the .01 level.

Finally, respondents were asked about their perception of the organizations that offer conservation easements (Table 4.7). Each individual was asked to rate the trustworthiness of both government agencies (e.g., the USDA) and non-governmental organizations (e.g., The Nature Conservancy). As expected, NIPF that have more trust in government and independent agencies are more likely to consider placing their woodland under conservation easement.

Evidence of this is illustrated by the significance of the sample means at the .01 level.

Table 4.7: Perception of organizational trustworthiness as reported by NIPF landowners in West Virginia, 2011.

\begin{tabular}{|c|c|c|}
\hline \multirow[b]{2}{*}{ Description } & \multicolumn{2}{|c|}{$\begin{array}{c}\text { Mean Likert Score } \\
(1 \text { to } 4 ; \text { where } 1=\text { none and } 4=\text { a lot })\end{array}$} \\
\hline & Yes & No \\
\hline Trustworthiness of governmental agencies $* * *$ & 2.53 & 2.10 \\
\hline $\begin{array}{l}\text { Trustworthiness of non-governmental } \\
\text { organizations*** }\end{array}$ & 2.38 & 1.86 \\
\hline
\end{tabular}

*** T-Test significant at the .01 level. 


\subsubsection{Demographics}

NIPF landowners do not always live in the same county as their forest property. With this in mind, respondents were asked about their county of primary residence (Figure 4.13). Much like the question pertaining to location of woodland property, the West Virginia Resource Conservation and Development Council's regional map was utilized for grouping the counties into regions (USDA NRCS 2011); with the addition of an "Out-of-state" category for individuals not living in West Virginia. NIPF landowners residing in the Eastern Panhandle, Mountain and "Out-of-state" regions of the state appear somewhat more likely to consider entering into a woodland conservation easement program. The chi-square test between all regions of primary residence and willingness to consider an easement program was significant at the .01 level. 


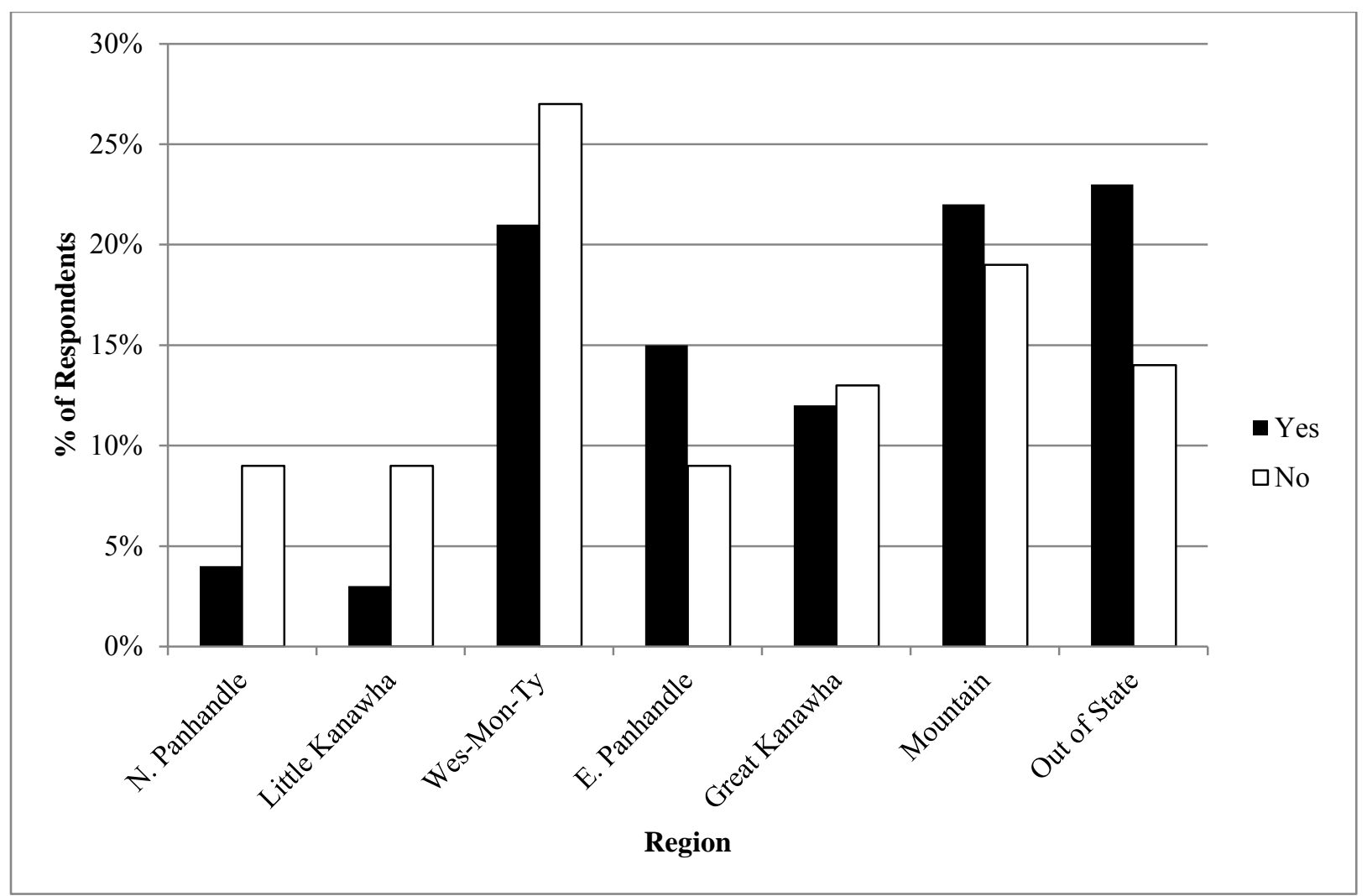

Figure 4.13: Location of primary residence as reported by NIPF landowners in West Virginia, $2011(n=464)$.

Questions regarding landowner age and income were also asked in the demographic section of the survey questionnaire (Table 4.8). These summaries show that NIPF willing to consider a forestland conservation easement are slightly younger (T-test significant at the .01 level) and average a higher income (T-test significant at the .05 level) then those not willing to consider.

Table 4.8: Age and income as reported by NIPF landowners in West Virginia, 2011.

\begin{tabular}{|l|c|c|}
\hline \multirow{2}{*}{ Description } & \multicolumn{2}{|c|}{ Mean } \\
\cline { 2 - 3 } & Yes & No \\
\hline Age (years)*** & 62.85 & 65.82 \\
\hline Income (dollars)** & $\$ 85,405.79$ & $\$ 67,342.08$ \\
\hline
\end{tabular}

** T-Test significant at the .05 level.

*** T-Test significant at the .01 level. 
Chi-square results between level of education and likelihood of enrollment showed significance at the .01 level (Figure 4.14). The chi-square test between gender and whether or not the respondent was willing to consider participation in an easement program (Figure 4.15) was not significant (P-value 0.224).

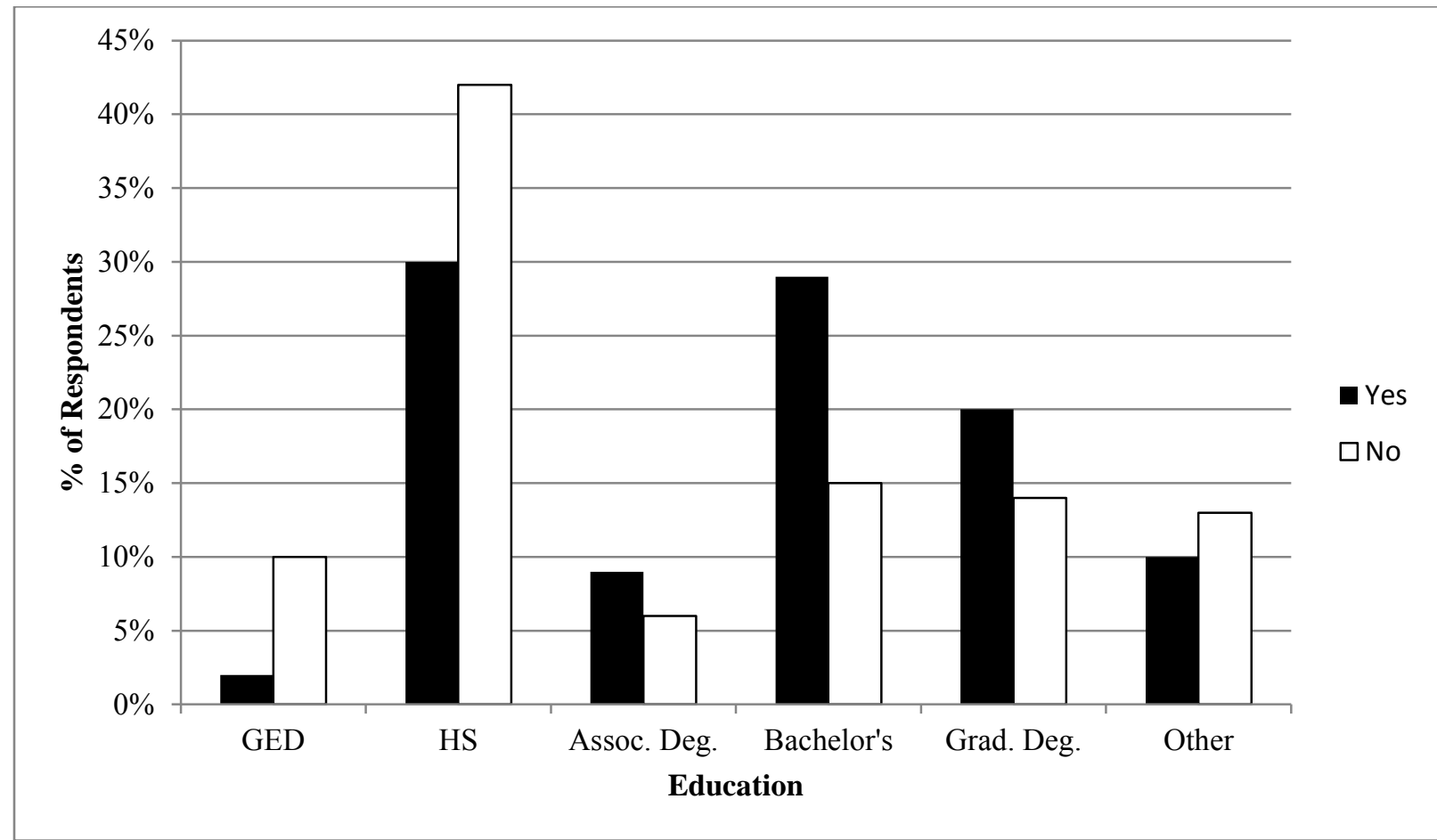

Figure 4.14: Level of education as reported by NIPF landowners in West Virginia, $2011(\mathrm{n}=459)$. 


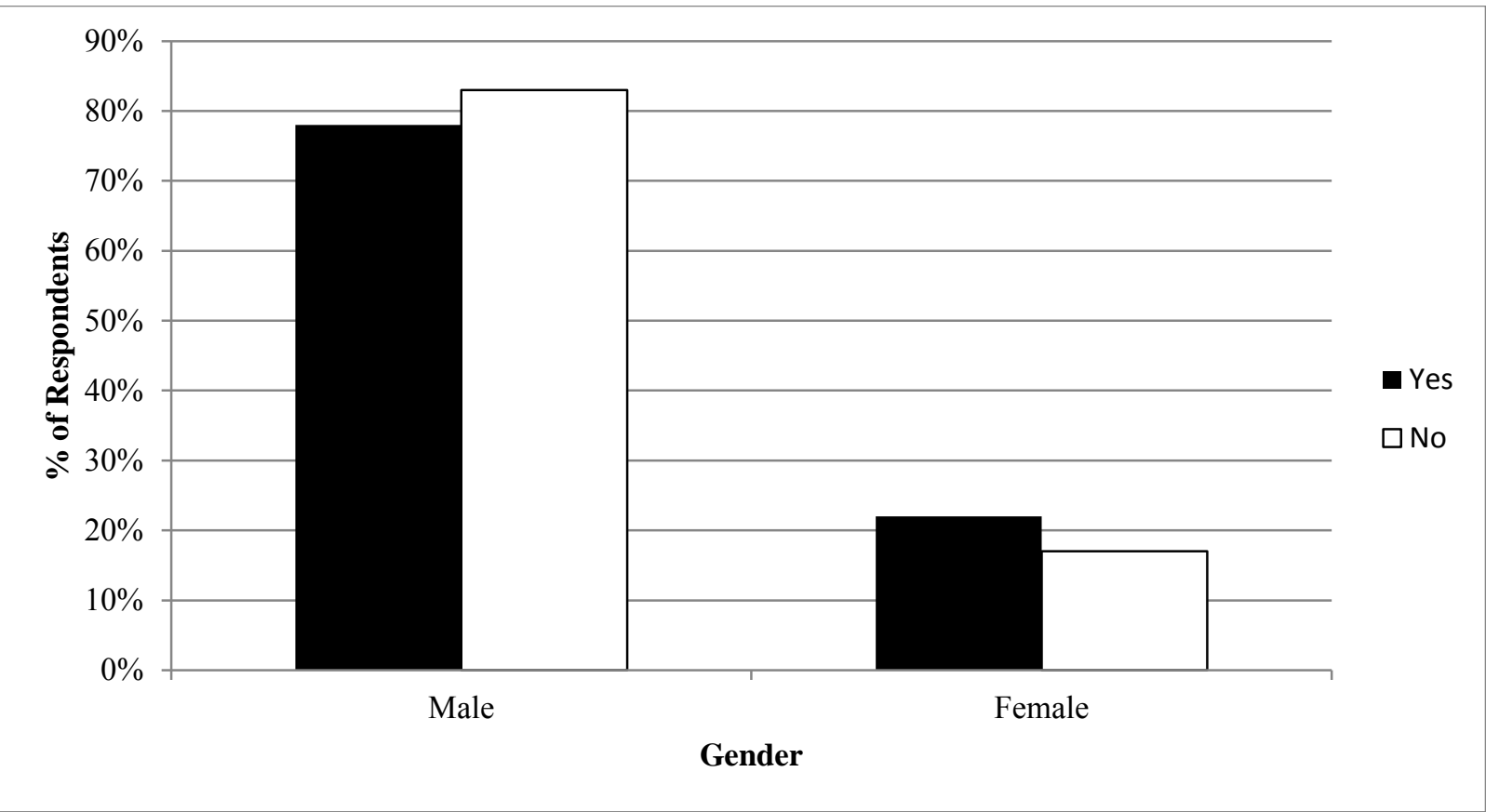

Figure 4.15: Gender as reported by NIPF landowners in West Virginia, $2011(\mathrm{n}=479)$. 


\subsubsection{Factors Affecting Participation in a Forest Conservation Easement Program}

Table 4.9: Logistic regression model evaluating West Virginia NIPF landowner participation in conservation easements, 2011.

\begin{tabular}{|c|c|c|c|c|c|}
\hline Variable & Estimate & & Std Error & Mean & $\begin{array}{l}\text { Odds } \\
\text { Ratio } \\
\end{array}$ \\
\hline Constant & -6.1782 & $*$ & 3.6811 & & \\
\hline TIMUSE & 0.3919 & & 1.0333 & 0.10145 & 1.47973 \\
\hline ACRES & 0.0007 & & 0.0022 & 144.724 & 1.00073 \\
\hline FOCOV & 0.0230 & $*$ & 0.0134 & 66.2027 & 1.02334 \\
\hline YRSACQ & -0.0558 & $* *$ & 0.0269 & 24.6884 & 0.94573 \\
\hline TRNSFR & 1.6145 & $* *$ & 0.7710 & 0.56522 & 5.02540 \\
\hline PROTAX & 1.2087 & $*$ & 0.7145 & 0.31159 & 3.34925 \\
\hline DISCIV & 0.1780 & $* * *$ & 0.0696 & 7.92391 & 1.19719 \\
\hline DISWIL & -0.0592 & $* *$ & 0.0256 & 15.2827 & 0.94255 \\
\hline CONNEX & -0.2448 & & 0.4564 & 3.65217 & 0.78282 \\
\hline RIGHTS & -0.5916 & $*$ & 0.3195 & 2.89130 & 0.55347 \\
\hline VALCON & 0.7981 & $* * *$ & 0.2563 & 5.93478 & 2.22124 \\
\hline PERORG & 0.9449 & $* * *$ & 0.3067 & 4.45652 & 2.57246 \\
\hline DEVELP & -1.9047 & $* *$ & 0.9662 & 0.21014 & 0.14887 \\
\hline SUBCTY & -1.7688 & $* *$ & 0.8841 & 0.28986 & 0.17054 \\
\hline PERINC & 0.0150 & & 0.0210 & 7.54891 & 1.01511 \\
\hline INVEST & -1.2322 & $*$ & 0.7154 & 0.69565 & 0.29166 \\
\hline CONSRV & -0.1459 & & 0.1034 & 19.0507 & 0.86421 \\
\hline POLICY & -0.4624 & & 0.4433 & 2.38406 & 0.62978 \\
\hline AGE & 0.0350 & & 0.0365 & 61.3768 & 1.03572 \\
\hline EDLVL & 1.6660 & $* *$ & 0.6917 & 0.55072 & 5.29085 \\
\hline INC & $0.124 \mathrm{D}-05$ & & $0.469 \mathrm{D}-05$ & 77706.5 & 1.00000 \\
\hline GENDER & -1.5438 & $*$ & 0.8553 & 0.85507 & 0.21357 \\
\hline EASTRN & 4.0796 & $* * *$ & 1.2687 & 0.13043 & 59.1241 \\
\hline Likelihood Ratio & -45.2481 & & & & \\
\hline Chi-Square Value & 97.2902 & & & & \\
\hline P-Value & 0.00000 & & & & \\
\hline Total number of observations: & 138 & & & & \\
\hline
\end{tabular}

*** Significant at the $1 \%$ level, ** Significant at the $5 \%$ level, * Significant at the $10 \%$ level 
The empirical model correctly predicted $84.78 \%$ of the responses and had a McFadden $\mathrm{R}^{2}$ value of .51809. Six variables from the property information section were significant (FOCOV, YRSACQ, TRNSFR, PROTAX, DISCIV and DISWIL). Similarly, six variables representing the motivations and perceptions of NIPF in West Virginia were significant (RIGHTS, VALCON, PERORG, DEVELP, SUBCTY and INVEST). The last section of the survey questionnaire, demographics, had three significant predictors (AGE, EDLVL and EASTRN). Finally, there were eight variables in the model that were not significant (TIMUSE, ACRES, CONNEX, PERINC, CONSRV, POLICY, AGE and INC).

FOCOV was positively related to willingness to consider; meaning the larger percentage of forest cover an individual has on their property than the more likely they may be to participate in an easement program. Inversely, YRSACQ was negatively correlated to the dependent variable (CNSDR); implying landowners that have owned their woodland for a shorter time period are more likely to enroll. TRNSFR had the hypothesized sign. The positive coefficient explains that NIPF who are concerned with transferring their private property rights to another generation are more likely to participate in a forest conservation easement program. PROTAX was positive as expected, which means individuals concerned with their ability to pay their current property taxes are more likely to participate.

DISCIV was expected to return negative in the model, but the coefficient came back positive. Contrary to the hypothesis, this means that landowners with property further away from metropolitan areas (where development pressure is probably lower) are more willing to consider an easement. However, it is important to note, the mean distance in the model from the nearest town or city was merely 7.92 miles. Furthermore, the means analysis showed respondents willing to consider only being an average of 10.25 miles away. Both relatively close to urban civilization 
and likely still subject to some development pressure. Lastly, DISWIL had the expected negative sign, purporting landowners closer to public lands may be more likely to enroll.

RIGHTS was negatively correlated to participation, indicating landowners that are less concerned with a conservation easement infringing on their private property rights are more willing to consider enrolling in an easement program. VALCON was positive, which supports the assumption that NIPF landowners who believe their property to have conservation value and that easements are important to West Virginia's landscape are more probable to enroll. The coefficient for PERORG was above zero as hypothesized. This forwards the notion that NIPF landowners who believe government and non-governmental organizations to be fairly trustworthy are more likely to ease their woodland.

When landowners believe development rights or "other" (e.g., mineral rights, retirement, privacy) to be the most valuable aspect of their property, the less likely they will be to ease the land. A statement affirmed by the negative sign for DEVELP in the model. SUBCTY unexpectedly returned a negative coefficient. One possible explanation is that despite an awareness of the conservation easement alternative; these individuals may not have an appreciation for rural environments and their natural resources due to location of residence during formative years. INVEST was negative, corroborating the hypothesis that landowners who do not believe their property to be a monetary investment are likely participants.

All three significant demographic variables had the expected coefficient. NIPF landowners with an associate's degree or more (EDLVL) were positively correlated to the dependent variable. GENDER was negative, meaning women are more willing participate, and finally, EASTRN was positive in the estimation. It's highly significant coefficient affirming the 
hypothesis that individuals who live and own woodland in the eastern panhandle of West Virginia are more likely to enroll in a forest conservation easement program.

\subsubsection{Discussion}

Natural resources are vital to West Virginia. Forestland provides the state with economic stability through commercial logging and recreation, as well as many other values. With over ten million of the twelve million acres of woodland privately owned (USDA Forest Service 2010c); conservation of the resource is essential. Therefore, studying NIPF land management behavior is a relevant endeavor and may have policy implications. It is particularly important in the eastern panhandle where development pressure is high (American Farmland Trust 2009).

The location of all West Virginia's hardwood forests in relation to urban centers make them important to the state's economic stability (Jennings and McGill 2005). Yet, the eastern panhandle of West Virginia has an elevated level of urbanization pressure because of its proximity to Baltimore, MD and Washington, DC (Jennings et al 2003); and for this reason, has been the focus of previous research concerning the state's Forest Stewardship Plan. But, few studies have focused on landowner motivations for participation in conservation easements, and even less have looked at non-agricultural land (Farmer 2009). Empirical research that studies motivation for forestry activity presents a theoretical foundation for land use decisions that permits diverse criteria across a mixed type of landowners (Koontz 2001).

There are several factors influencing NIPF participation, and these results help to illuminate some of the more prevalent motivators. Primary use or example; timber production, recreation, scenic quality and the category entitled "other" all showed more respondents willing to consider enrollment. In addition, initial analysis of motivations and perceptions indicated NIPF that view recreation, environment and scenery to be the most valuable aspects of their 
property appear likely to ease their forestland. Therefore, the wide ranging capabilities of conservation easements are an excellent opportunity to practice efficient resource management and ultimately good stewardship. In addition, a noticeably large portion of the sample perceived timber as the most valuable facet of their land; and as mentioned previously, landowners primarily utilizing the property for timber production were inclined to consider participation. The implications are that despite the apparent lack of enrollment, conservation easements have potential within the NIPF landowner demographic; specifically those interested in actively managing their forest resources.

As acreage increases, so does the landowner's probability of enrolling in a conservation assistance program (Kaetzel et. al 2009). The means comparison in this study found the same result, individuals willing to consider participation averaged almost 100 acres more than those unwilling; indicating these individuals may be somewhat more likely to participate in a woodland conservation easement program. In the model, the approximate percentage of forest cover had the same affect. According to Farmer (2008), "Few, if any models are available that consider the variables associated with individuals who place CEs upon private property for ecological reasons and within forested landscapes" (p. 113). The positive and significant coefficient suggests that as forest cover increases on one's property, so does their willingness to participate in a forest conservation easement program. An important point, because many landowners in West Virginia, NIPF as well as others, are likely to have woodland on their land. Furthermore, timber management may not be a goal of the landowner (Fortney et al. 2011). Therefore, it will be necessary to advocate the entire spectrum of alternatives a conservation easement affords in the future. 
The subheading potential motivations included: 1) personal connection to the land; 2) landownership in West Virginia providing a sense of place; 3) owner perception of civic responsibility; 4) amount of development pressure nearby; and 5) the respondent's perception of environmental policies in the United States. All the variables were statistically significant within this category except for the landowner's perception of environmental policies. The most influential factors toward participation were individuals with a substantial personal connection to the land and those who believe owning land in West Virginia provided them with a sense of place. Sense of place is an issue that Farmer (2009) stated would be important to future research regarding conservation easements. Also willing to consider were NIPF with an energetic perception of civic responsibility and/or those living around development pressure. Each of these topics, under the umbrella of potential motivations, had higher mean likert scores for the respondents who answered "yes" than the individuals who answered "no." Indicating they either felt strongly about the subject or, in the case of development pressure, the activity was higher in the surrounding area; the latter are locations where easement programs should focus recruitment.

This study shows there are several potential barriers which may also be influencing landowner decision making. Knowledge and exposure to information regarding conservation easements were both statistically significant. The analysis indicated NIPF landowners willing to consider had a better general understanding of conservation easements. This is concurrent with Kabii and Horwitz's (2006) hypothesis that individuals with more familiarity and awareness of the alternative may be motivated toward participation. Concern that the easement would infringe on private property rights also factored in; those who are not as worried about the agreement imposing on their rights were more likely to enroll. Both are issues that may be alleviated by developing outreach at the regional level. Furthermore, social marketing (e.g., Smokey the Bear) 
is an instrument that can positively motivate NIPF landowners toward good stewardship practices; however, such campaigns require organizational partnerships to be effective (Butler et al. 2007).

Conservation easements and their ensuing private property restrictions have been a contentious debate, and therefore its discussion calls for elaboration. Previous studies have found landowner leeriness of long-term timber leases to be associated with the belief they may lose control of their land and finances (McGill et al. 2008). Forever is a long time, and what if the practices and restrictions specified in the easement document inhibit future good use of the property? Merelender et al. (2004) ask, "How is permanent protection of the resource ensured while allowing for ecological change, inclusion of new data, changes in conservation needs, and other factors that may require changes in management to best serve the intentions of the easement?" (p. 57). Many easements that have management plans for forestry or ranching, allow flexibility within the agreement via continuous dialogue between land manager and easement grantee (Rissman et al. 2007a). Results from the means analysis and the empirical model reflect these sentiments. Again showing that, NIPF less concerned with the conservation easement infringing on their property rights, and inversely believing they allow for continued effective and efficient use of the parcel, are more likely to participate in a program.

NIPF perception of conservation and preservation topics had an influence on enrollment. This is in agreement with the assumption that landholders with a strong environmental conservation ethic might be more likely to enroll in perpetual covenants (Kabii and Horwitz 2006). Each subject: conservation, preservation, wildlife habitat, public recreation or education, historic preservation and scenic enjoyment were highly significant. Moreover, each had a larger 
mean likert score for the positive responses over the negative. This implies that NIPF likely to consider participation feel these issues are relatively more important.

According to the means analysis, property that has been in an individual's family for more than one generation appears to have a better chance of being placed in a woodland conservation easement program. Second, third and fourth generational landowners each had larger proportions of favorable responses concerning enrollment. This chi-square test being highly significant indicates family heritage as a positive influence toward participation. Furthermore, number of years since acquiring the property was a negative and significant variable in the model, implying NIPF landowners that have owned the parcel for a shorter time period are more likely to consider an easement. Joshi and Arano (2009) also found length of ownership to have a significant negative relationship in their model evaluating West Virginia landowners' decision making processes with regard to property management activities. It is possible that newer landowners are more aware and open to policy alternatives such as conservation easements. In addition, differences between newer and older landowners may influence their long term management activities (Joshi and Arano 2009).

Whether or not the landowner was concerned with transferring their property rights to future generations was significant in both the means analysis and the empirical model. Indicating that NIPF who are more concerned with handing their property to another generation are more likely to consider a forest conservation easement program. In fact, the odds ratio shows these individuals are approximately five times more likely to enroll; while holding other factors constant. Clearly an important predictor to participation, transferring rights looks to be influential across different types of landowners. Results from Ryan et al. (2003) show the desire to protect land for future generations as an influential factor for farmers who adopt conservation practices. 
So it appears that keeping property within the family or preserved for the next generations is a cross sectional factor. An important point because participants in West Virginia's farmland conservation easement program, Farm and Ranchland Protection Program (FRPP), often have forest cover on their property and consequently under conservation easement.

Financial incentives play a role in whether or not landowners adopt an easement. Initial results found individuals who depend more on their property for income and who are concerned with their ability to pay the current property taxes willing to consider enrollment. The model corroborates those findings with regard to property taxes; this predictor was positive and significant. Alluding to the fact that the more disquiet a landowner is about making the payment; the more likely they are to participate. The endowment received by placing a conservation easement on the property gives the landowner a variety of avenues for accepting the monetary benefit, ultimately providing financial aid that may alleviate their concern. So in the future, the various payment methods and tax incentives need to be made clear to likely participants. Furthermore, evaluating the current structure of the financial benefits to assess strengths and weaknesses would be beneficial.

The distance in miles an individual's property is from the nearest town or city was an important predictor. The coefficient was positive; indicating the further the property is from civilization the more likely the landowner is to enroll. This was contrary to the hypothesis, which held the closer the land is to urban areas the more willing the owner may be to participate because of development pressure. As mentioned earlier, this variable in the model was a continuous one, and both the average distances from civilization in the empirical model and the means analysis were relatively small. Moreover, living environment was significant in the means analysis; showing individuals living in a suburb, city (where development pressure is likely 
higher) and within a rural non-forest or "other" setting as more willing to participate. One possible explanation for the contradicting result is that most respondents surveyed own property close enough to a town or city to have been exposed to a certain amount of development pressure.

The distance in miles an individual's property is from the nearest public lands had the hypothesized coefficient. There are several benefits of conservation easements in West Virginia and one of those is providing a buffer zone to public lands (The Nature Conservancy 2010). This predictor was both negative and significant in the model, furthering the assumption that the closer a NIPF owner's land is to a public park or forest, the more willing they may be to consider easing the parcel. In addition, Rissman et al. (2007a) showed property eased as a buffer zone to be more likely utilized as a working landscape (e.g., ranching, farming and forestry), than those not contiguous to public or private nature reserves. Therefore, such parcels may be a good target for the WV Forest Legacy Program (FLP) which only accepts Working Forest Conservation Easements (WFCE's).

Similar to the notion of infringement on private property rights, landowners who perceive government and non-governmental organizations to be trustworthy are more willing to consider. Amount of organizational trustworthiness clearly plays a role in whether a private landowner will subordinate a portion of their interests in the property to an outside institution. This a finding supported by the variable's significance in both the initial analysis and the model. Furthermore, one must consider said property to have conservation value or easements to be important to West Virginia's landscape in general. A statement supported by the positive and significant association between conservation worth and likelihood to participate that is present in the empirical model and the means analysis. 
The variable addressing landowner perception of the most valuable aspect of the property was negative and significant; meaning individuals that believe development rights or "other" to be the key aspect of their land are less likely to participate. This discussion point coupled with the investment predictor is an interesting one. Whether or not an individual believes their property to be a monetary interest was negative and also significant. It is possible that landowners who consider their parcel to be a business venture believe the most lucrative returns are tied to the development rights. A feasible assumption would be that landowners who hold these as truths would not be willing to consider severing the development rights and essentially their perception of the most valuable aspect of the property. The inability to subdivide and develop, Kiesecker et al. (2007) laments, is the prevailing limitation for conservation easements.

NIPF landowners who were raised in a suburb or city were expected to be more likely to place a conservation easement on their property. The assumption was predicated on the idea that growing up in an urban environment would provide a person more opportunities to learn about, and become familiar with the alternative. The coefficient for this variable was negative and significant revealing landowners who were not reared in a suburb or city are more willing to consider. A conceivable explanation for this would be adults that spent their childhood years in a rural environment may have developed a greater appreciation for its natural amenities and family heritage. A theme that became evident in a recent qualitative analysis regarding motivations for adopting conservation easements in the Midwest: upon interviewing participants, Farmer (2009) had one interviewee state, "Well, number 1, was this was a family farm, I grew up there" (p. 98).

Age and income in the means analysis had slightly younger individuals, albeit both averages cited landowners in their sixties, with larger salaries as a portion of the group willing to consider. Amount of formal education is often utilized as a variable in demographic research and 
will sometimes mold individual behavior in land use decisions (Koontz 2001). Level of education for the initial analysis was highly significant and reported landowners with an associate's degree or better to be more likely to participate. These are similar findings to a study conducted in Colorado where landowners participating in private land conservation were "older, well-educated and relatively affluent" (Ernst and Wallace 2008, p. 119). With regard to model results; Joshi and Arano (2009) found education level of NIPF landowners in West Virginia to be significant and positively associated to whether or not they engage in timber harvesting activities. The odds ratio for the education level in this study implied that individuals who attained an associate's degree or higher have a likelihood of participation that is over five times greater than landowners with a GED or high school education; while holding other factors constant. Therefore, a safe assumption may be the more education woodland owners receive, the more likely they are to conserve as well as actively manage their forest resources.

Gender was negative and significant in the model as well, reporting women landowners in the state as more willing to consider an easement. A look back at the initial analysis showed NIPF landowners in West Virginia who are likely to participate in a forestland conservation easement program live and have woodland located in the Eastern Panhandle. This is as expected due to the high level of development pressure in that area (American Farmland Trust 2009). The eastern panhandle is close to major cities such as Baltimore, MD and Washington, DC which makes conservation of forestland essential (Jennings et al. 2003).

The empirical model strengthened the validity of the means analysis by supporting the initial finding. Individuals residing and owning woodland in the eastern panhandle of West Virginia are more willing to enroll. Conservation easements are a good defense mechanism against urban sprawl; all while providing flexible alternatives to forest management. These are 
prevalent issues in that region of the state. The coefficient representing that area in the model was positive and highly significant. Furthermore, the odds ratio indicates these landowners to be 59.12 times more likely to consider enrollment; while holding other factors constant. A result that provides evidence and emphasis to the belief that targeting these NIPF landowners for participation in forest conservation easement programs is critical.

In sum, this study validates the assumption that many factors affect NIPF landowner decisions. This finding is consistent with other studies regarding private forest landowners (Fortney et al. 2011; Kaeztel et al. 2009; Joshi and Arano 2009). There were several significant predictors from the property information, motivations and perceptions and demographic categories. Furthermore, the empirical model was significant as a whole at the .01 level. This rejection of the null hypothesis affirms that NIPF landowners willing to consider enrolling their property in a forest conservation easement program are not the same as those unwilling to consider. This finding establishes helpful information about physical attributes, such as property and demographics in addition to intrinsic motivations, which may help in developing a likely participant profile. Yet, conservation easements appear to have a negative image with regard to the NIPF demographic in West Virginia. As illustrated earlier, the majority of respondents (67\%) answered "no" when asked whether or not they were willing to consider placing a forestland conservation easement on their property; a finding which can hopefully be curtailed by results from this study.

It is important to explore motivations for land management by woodland owners because they have the majority of the forestland at the local and national level. Understanding their decision making processes will be essential to timber availability in the future (Joshi and Arano 2009). The primary means of marketing for conservation easement programs in West Virginia is 
at the local level, and there is a need for better outreach at the regional level (Hatton 2011). One recommendation would be to create awareness of the alternative on a larger spatial scale. This could increase participation and address insights provided by the model such as ability to transfer rights, financial benefits, promote organizational trustworthiness and increase visibility. Lastly, these results contribute to the body of research regarding NIPF behavior. It also provides a quantitative empirical basis for future research regarding conservation easements; as well as furnishing useful information to both practitioners and private landowners. 


\section{Chapter V: Attributes of Conservation Easement Participants}

"In addition to preventing development, I feel that woodlands should be managed using the best practices of sustainable forestry. It was a difficult choice for me to choose one over the other. In the final analysis, preventing development allows the other to continue un-challenged."

- Conservation easement participant respondent

\subsection{Introduction}

In addition to studying the motivations and perceptions of NIPF non-easement participating landowners in West Virginia; a look at the individuals who are participating in conservation easements provides a more comprehensive evaluation of their usage in the state. Previous studies have surveyed landowners that own eased property (Farmer 2009, Ernst and Wallace 2008, Farmer 2008, Wallace et al. 2008 and Rilla 2002). But difficulty in obtaining private landowner contact information for participants may be one reason there has not been a tremendous amount of literature directly surveying this demographic. Similar to Wallace et al. (2008), key contacts enabled this sample data to be collected. Although no direct comparisons have been made between NIPF non-easement participants and the various classifications of easement participants, analyzing the participant questionnaire provides insightful information. These results further the understanding about attributes of conservation easement landowners in West Virginia.

A conservation easement is a legal agreement between a private landowner and an accredited conservation organization that delimits future land uses to preserve its conservation value (Byers and Ponte 2005). These documents are an efficient tool for protecting natural resources while still attaining landowner goals. Conservation easements are an all-encompassing alternative. To illustrate, there are "historic preservation easements, agricultural preservation easements, scenic easements, open-space easements, forever-wild easements, working-forest 
easements, conservation restrictions, and so on" (Byers and Ponte 2005, p. 3). Individuals clearly wish to maintain their autonomy, and are therefore partial to inducement-based, voluntary conservation for privately owned land resources (Merelander et al. 2004). It is likely that for this reason conservation easement usage has increased dramatically in recent years. In fact, conservation easements are fast becoming one of the most prominent tools for protecting working landscapes in America (Rissman et al. 2007b).

Working landscapes, privately owned land and natural resources are important issues to West Virginia. It is the third most heavily forested state in the country, and NIPF landowners own more than three quarters of the woodland. Yet, forestland conservation easement programs in West Virginia do not appear to be reflecting the nationwide popularity of the alternative. For example: the Land Trust of the Eastern Panhandle (LTEP) only has three (forested) easement acquisitions, of which only one has a forest management plan (Smith 2010); and West Virginia's Forest Legacy Program (FLP) had no acquisitions in 2009 (USDA Forest Service 2010c). Assessing in state landowners who are participating in conservation easements will provide further information into motivational factors.

\subsection{Methodology}

\subsubsection{Data}

Mail survey data was collected in the fall of 2010 for this sample. The target population was landowners with property under conservation easement in West Virginia. The questionnaires were sent to, and administered by, government and non-governmental organizations interested in the study. These agencies were either located in West Virginia and/or held conservation easements with individuals whose eased property is in the state. The private landowner information was kept completely confidential to even the researchers. 
Structuring and development of the survey instrument was based on "Internet, Mail, and Mixed-Mode Surveys: The Tailored Design Method" (Dillman et al. 2009). The mailing process was tailored differently due to the necessary collaboration with government and nongovernmental organizations. A combined cover letter and questionnaire was sent in November 2010 to the co-operative organizations. Key contacts within these organizations then forwarded them on to their clients participating in conservation easements. There were no further mailings because of time constraints. The substantive material for the questionnaires were based on research and questionnaire templates from The Nature Conservancy (2010), Farmer (2009), Kaetzel et al. (2009), Fortney (2009), Ernst and Wallace (2008), Kabbi and Horwitz (2006), DeGooyer and Capen (2004), Ryan et al. (2003), Koontz (2001) and Bliss et al. (1997).

\subsubsection{Analysis}

The four sections in the survey were entitled: 1) property information; 2) motivations and perceptions; 3) conservation easement participants; and 4) demographics. Respondents were asked questions that were meant to provide new data about conservation easement landowners. Survey construction was grounded in, and guided by, previous research in order to gain a better understanding of the easement alternative; specifically in the state of West Virginia. Data analysis in this chapter is comprised of summary statistics, computed in Microsoft Excel 2010, acquired from the conservation easement participant questionnaire.

\subsection{Results}

\subsubsection{Survey Response}

The target response rate for this sample was $30 \%$. There were 176 surveys mailed to government and non-governmental organizations to be forwarded on to their landowners. Out of 
the possible 176 responses, 55 questionnaires were returned to West Virginia University and utilized as the database for this study. Therefore, the response rate for the conservation easement participant survey was $31.3 \%$.

\subsubsection{Property Information}

Respondents were asked about the primary use of their conservation easement property (Figure 5.1). The majority of landowners claim farmland and recreation as the main function of the land; with noticeably fewer respondents who categorized their primary use as scenic quality and residence. One prominent aspect of this graph is timber production coming in second to last with only $7.5 \%$ of the distribution. There were 53 total observations in this figure $(n=53)$.

Most of the conservation easement participants were first generational landowners (Figure 5.2). In fact, $64.2 \%$ of the demographic were the individuals who had acquired the property. A large drop occurred between first and second generation. 


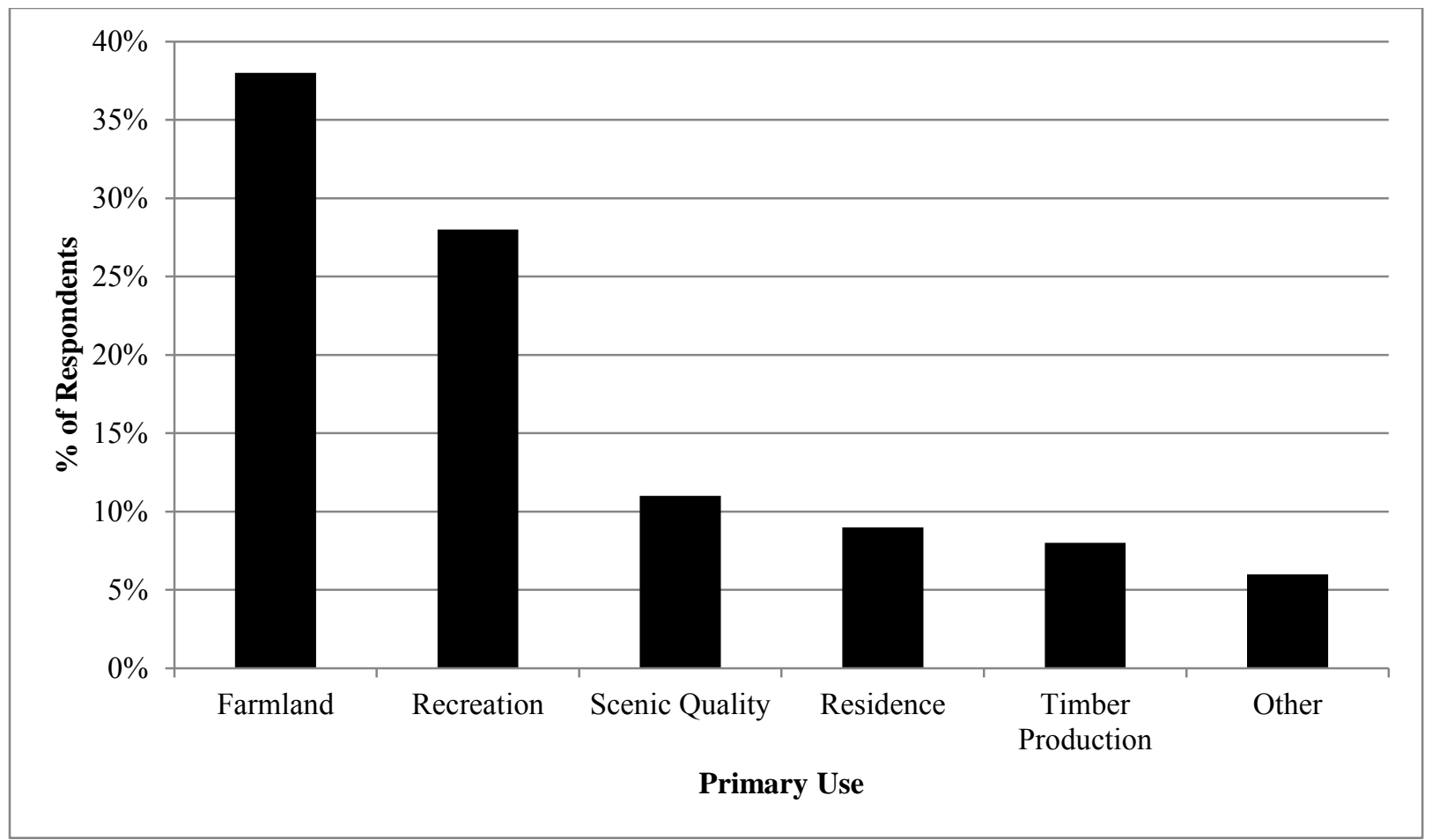

Figure 5.1: Primary use of land as reported by CE participants in West Virginia, 2011 ( $\mathrm{n}=53)$.

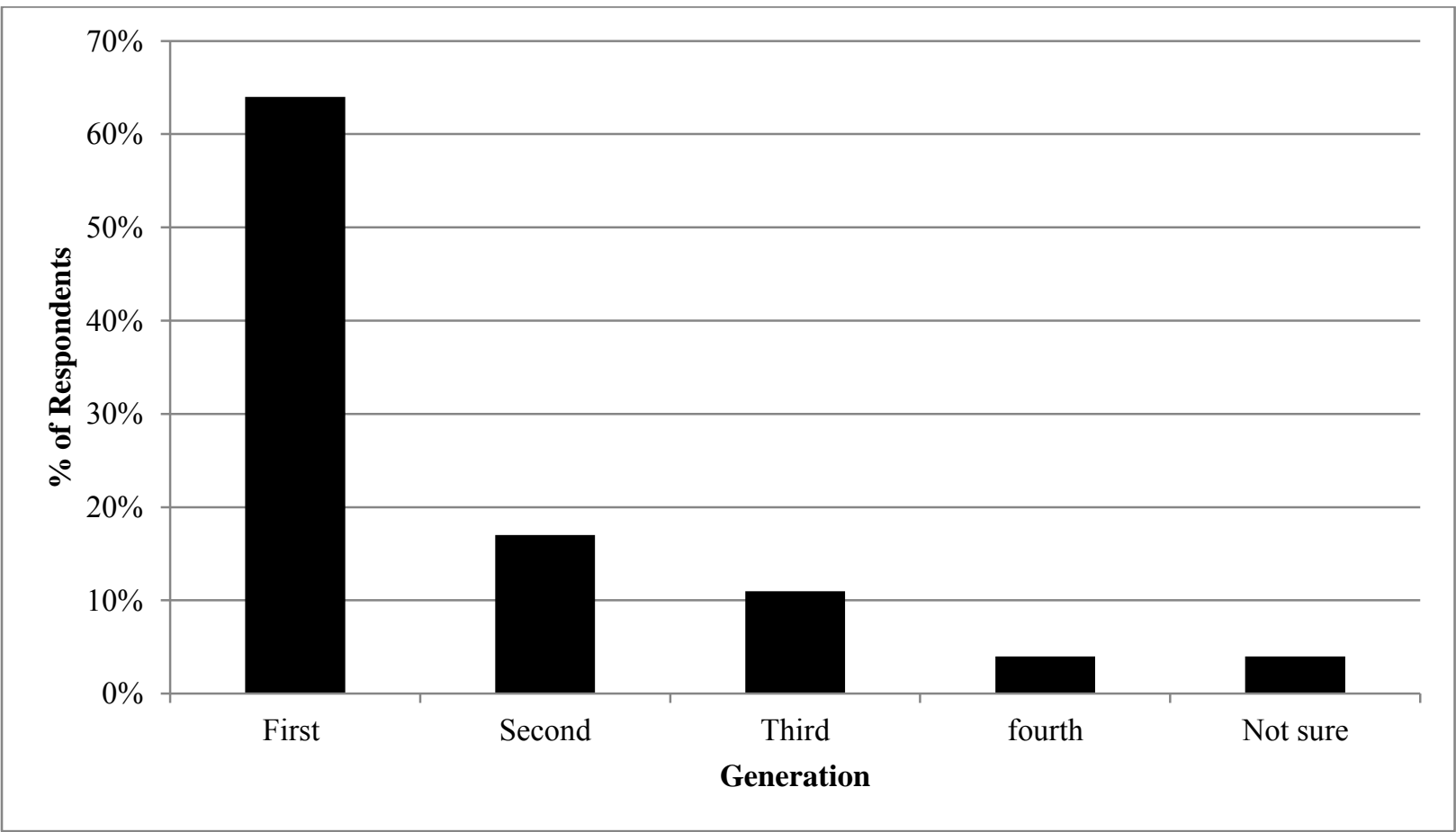

Figure 5.2: Generation of landowner as reported by CE participants in West Virginia, 2011 $(n=53)$. 
Landowners were asked about whether they were concerned with transferring their property rights to a future generation. More individuals answered "yes" to this question then "no" but there was not a large difference in the proportions (Figure 5.3).

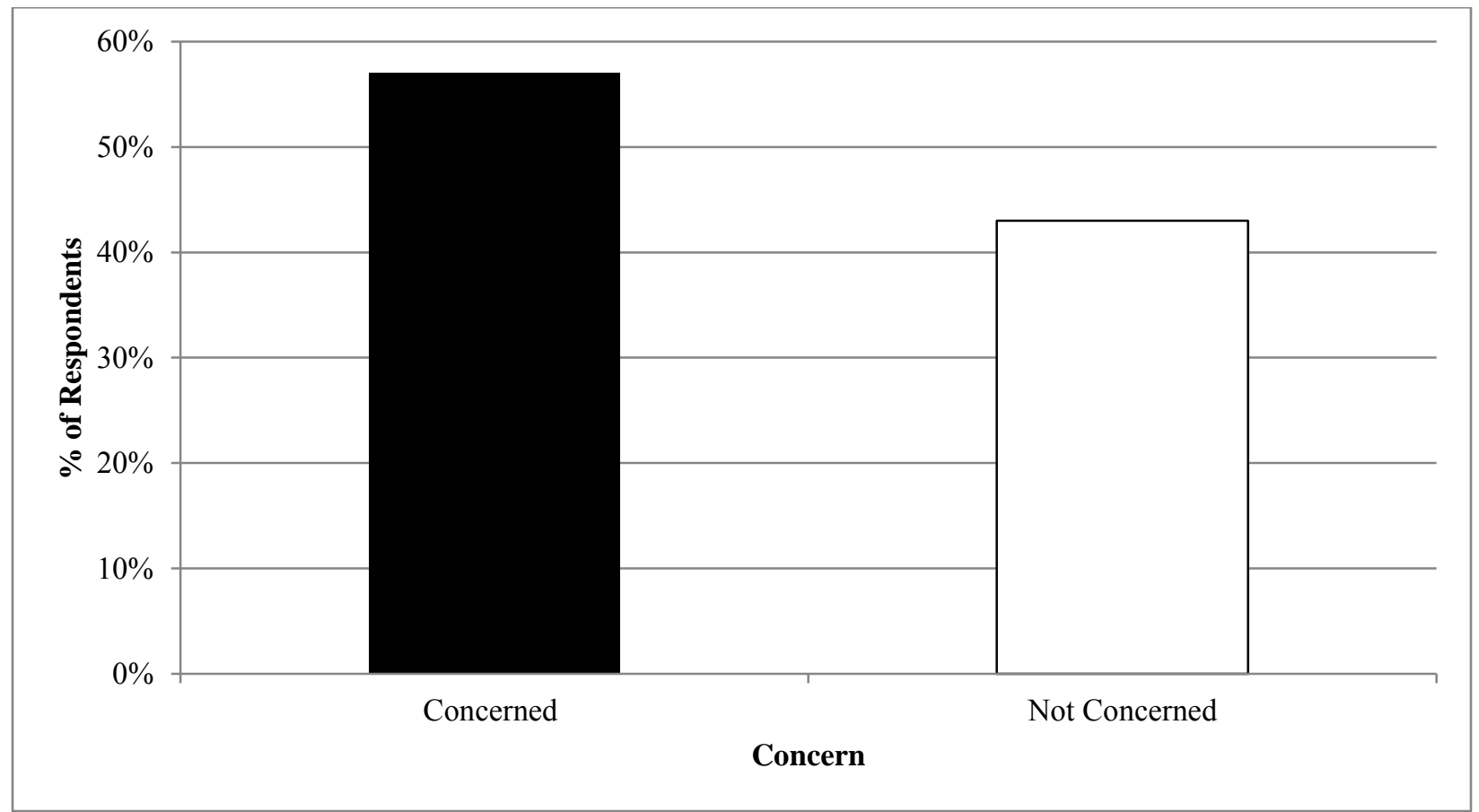

Figure 5.3: Landowner concern about transferring property rights to future generations as reported by CE participants in West Virginia, $2011(\mathrm{n}=53)$.

With regard to their ability to pay current property taxes, few of the respondents were concerned (Figure 5.4). Approximately three quarters of the participant demographic said they were not worried about paying (74.5\%), while the remaining quarter said that it was something they were uneasy about (25.5\%). These individuals were also asked if they were raised on or near the land they owned; and most said they had been raised elsewhere (Figure 5.5). 


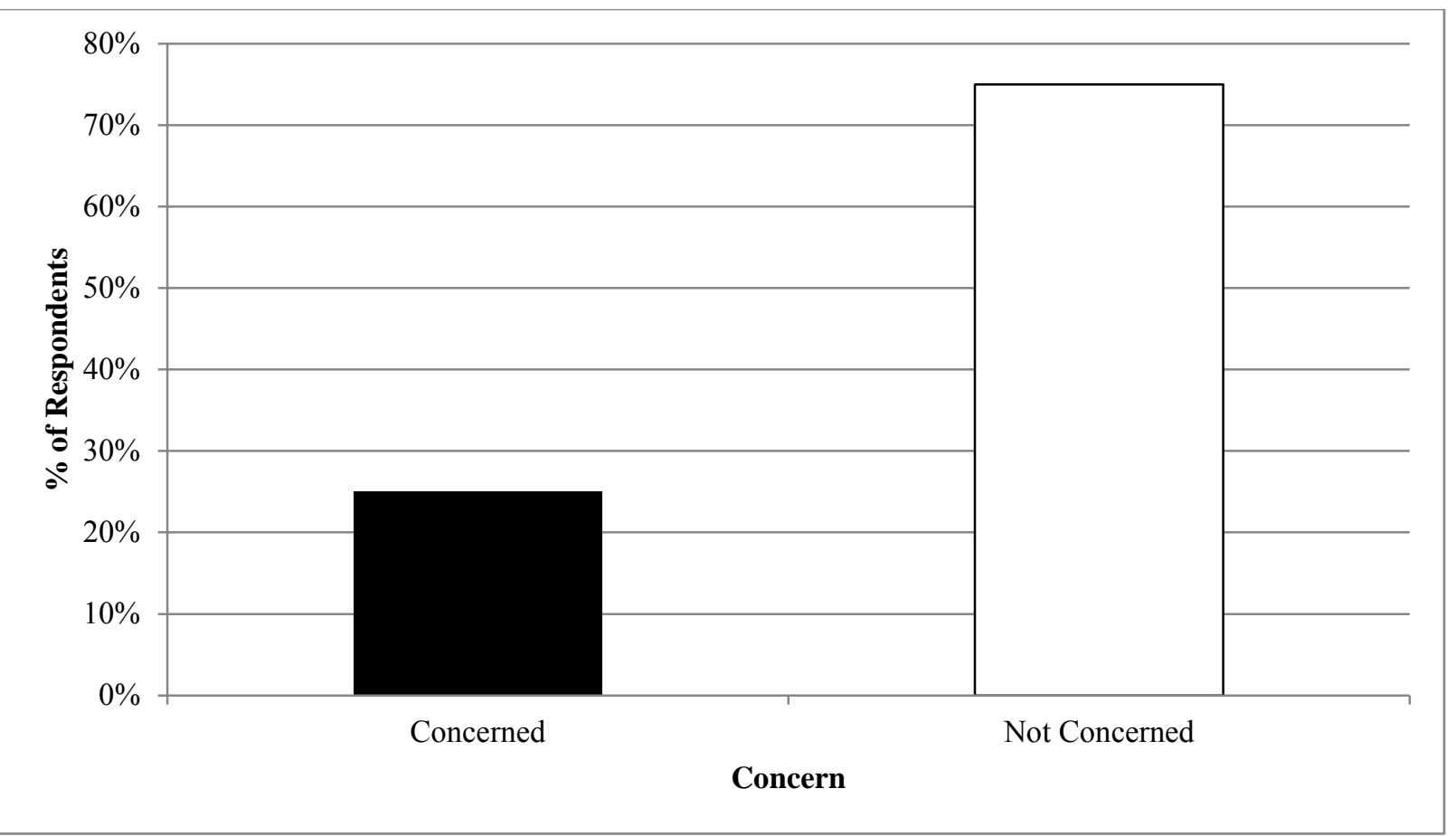

Figure 5.4: Landowner concern with their ability to pay the current property taxes as reported by CE participants in West Virginia, $2011(n=55)$.

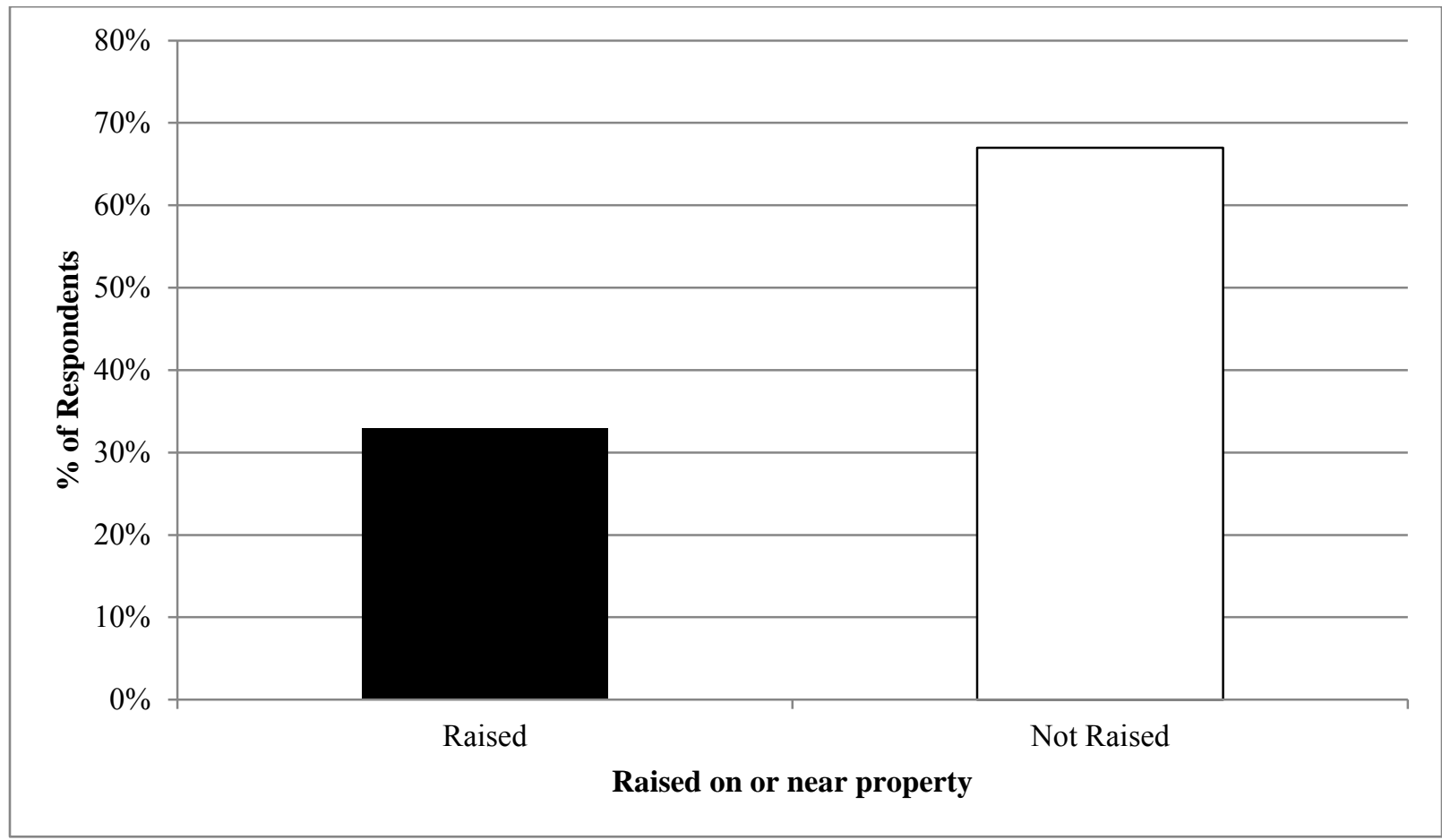

Figure 5.5: Whether the landowner was raised on or near the property they own as reported by CE participants in West Virginia, $2011(n=55)$. 
Averages are listed in Table 5.1 for the discrete variables in the property information portion of the participant survey. As shown, mean acreage for West Virginia landowners with conservation easements on their property is 300.75 . These parcels have the majority of that acreage under forest cover. The average percent forest canopy showed over half of each property with woodland coverage. Individuals had not owned these parcels for an extended length of time. And lastly, mean distance from the nearest town or city and from the nearest public lands (e.g., state or national park) were both below ten miles.

Table 5.1: Property statistics as reported by CE participants in West Virginia, 2011.

\begin{tabular}{|l|c|}
\hline \multicolumn{1}{|c|}{ Description } & Mean \\
\hline Acres owned & 300.75 \\
\hline Percent forest cover & 65.25 \\
\hline Length of ownership (years) & 30.10 \\
\hline Distance from nearest town/city (miles) & 6.70 \\
\hline Distance from nearest public lands (miles) & 9.20 \\
\hline
\end{tabular}

\subsubsection{Motivations and Perceptions}

When asked about the most valuable aspect of their property, the analysis showed easement participants in West Virginia perceiving agriculture most often and timber production least often (Figure 5.6). Agriculture recorded $28.8 \%$ of the responses with timber production having merely $1.9 \%$. 


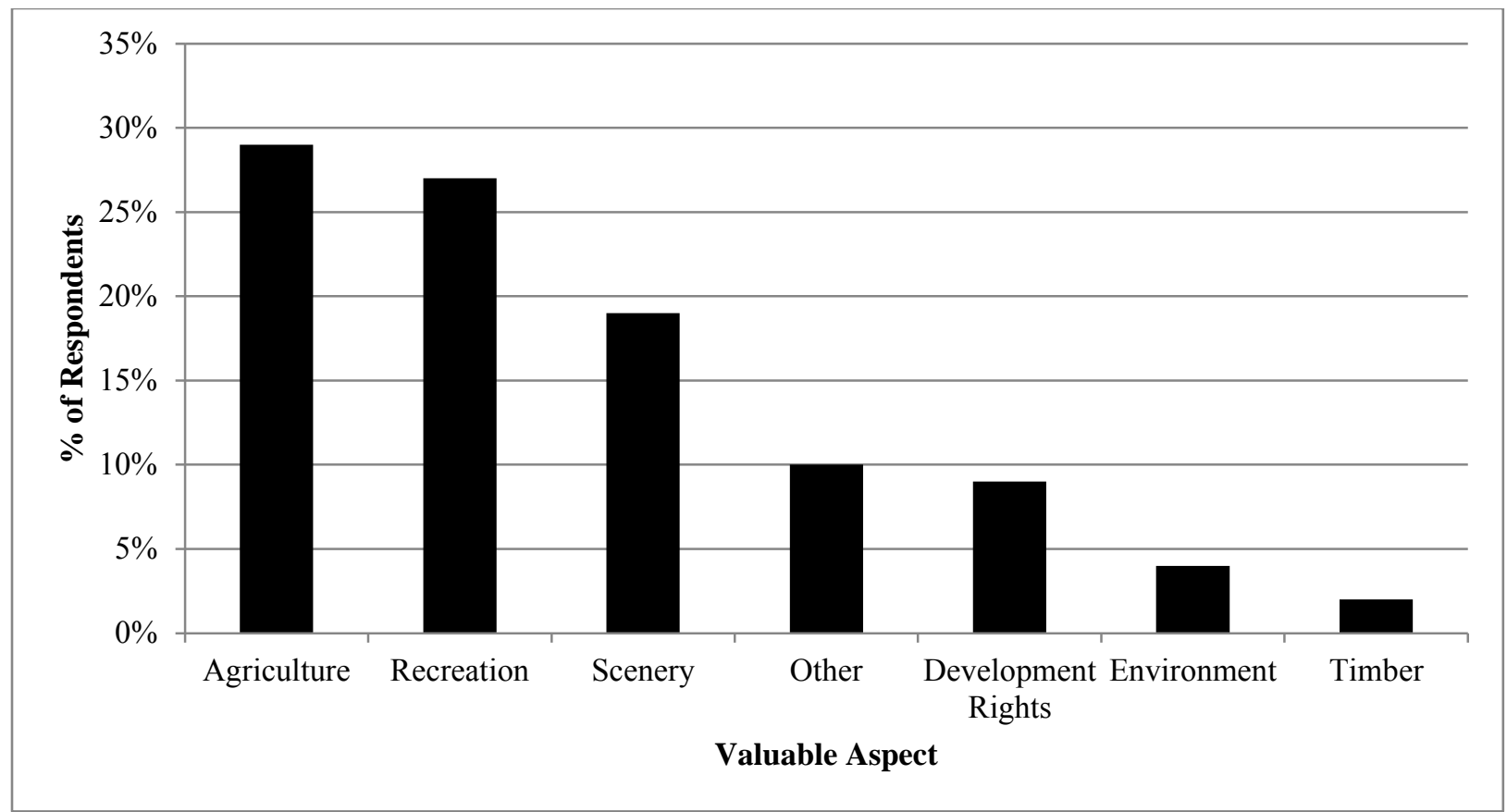

Figure 5.6: Landowner perception of the most valuable aspect of their property as reported by CE participants in West Virginia, $2011(\mathrm{n}=52)$.

Most of the participants surveyed were raised on a farm or in a suburb (Figure 5.7). The majority of respondents are also currently living on a farm or in a suburb (Figure 5.8). 


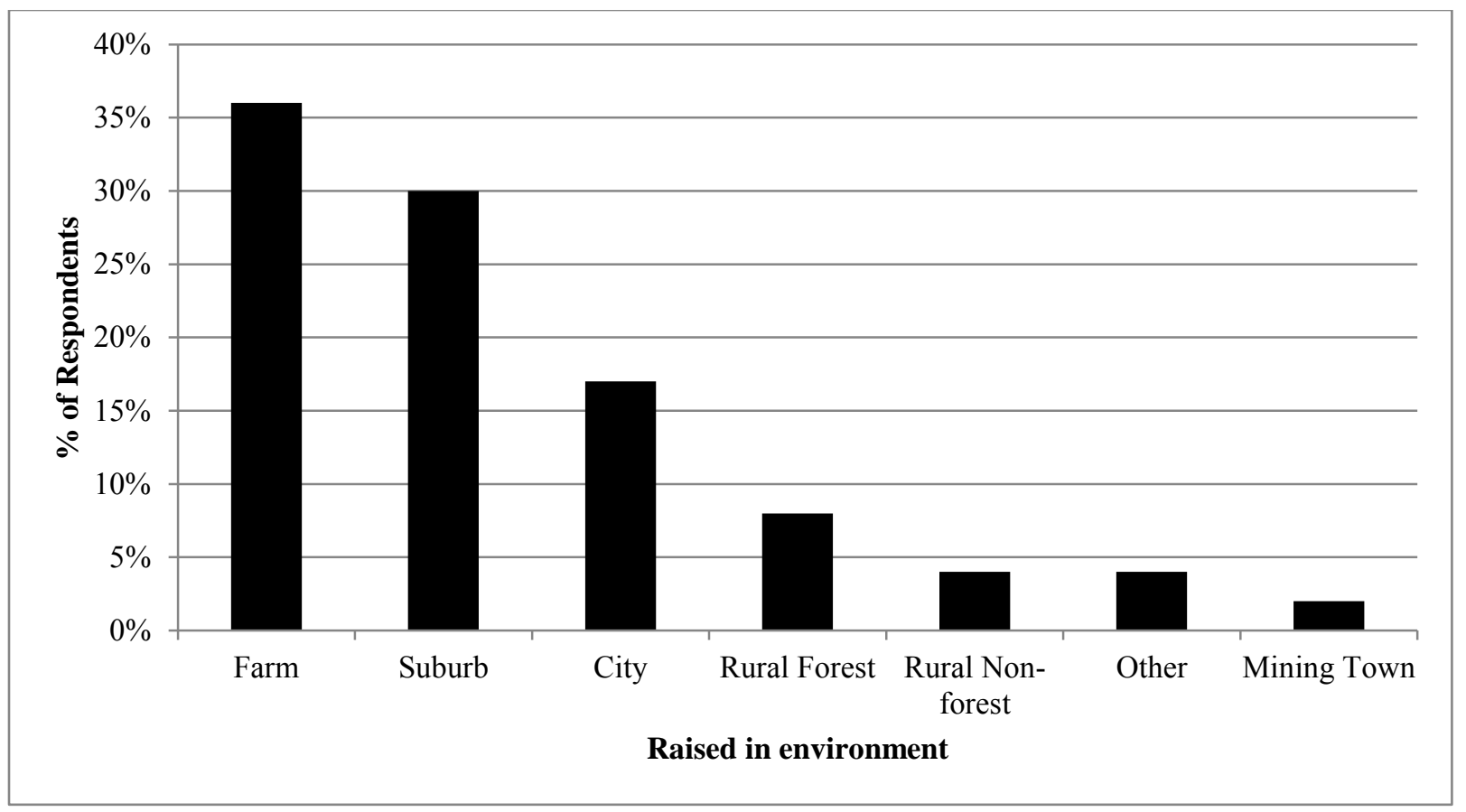

Figure 5.7: Type of environment respondent was raised within as reported by CE participants in West Virginia, $2011(\mathrm{n}=53)$.

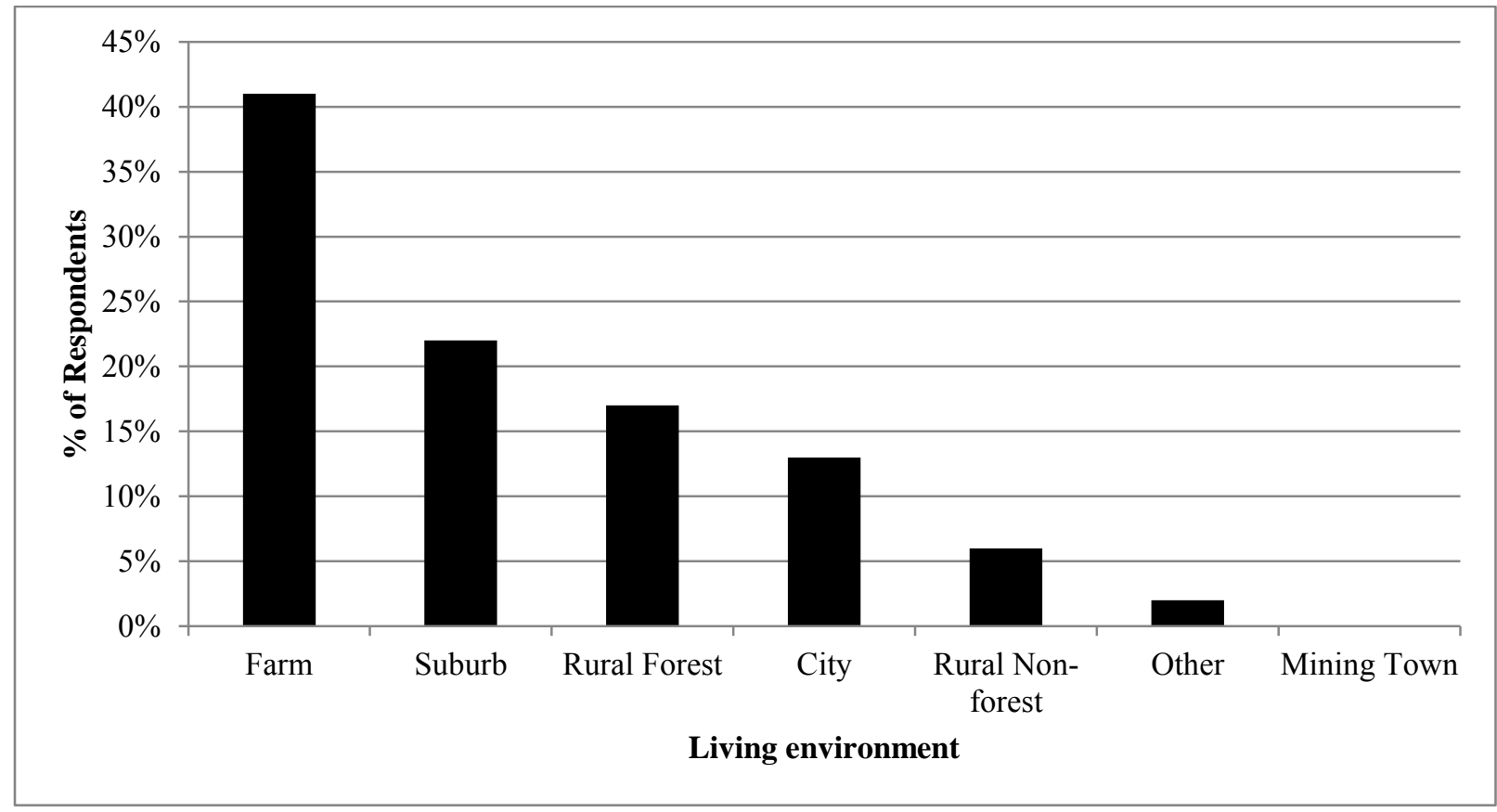

Figure 5.8: Current living environment as reported by CE participants in West Virginia, 2011 $(n=54)$. 
A little over half of the easement participants believed their property was a monetary investment (Figure 5.9); with the remainder of the proportion feeling that it was not.

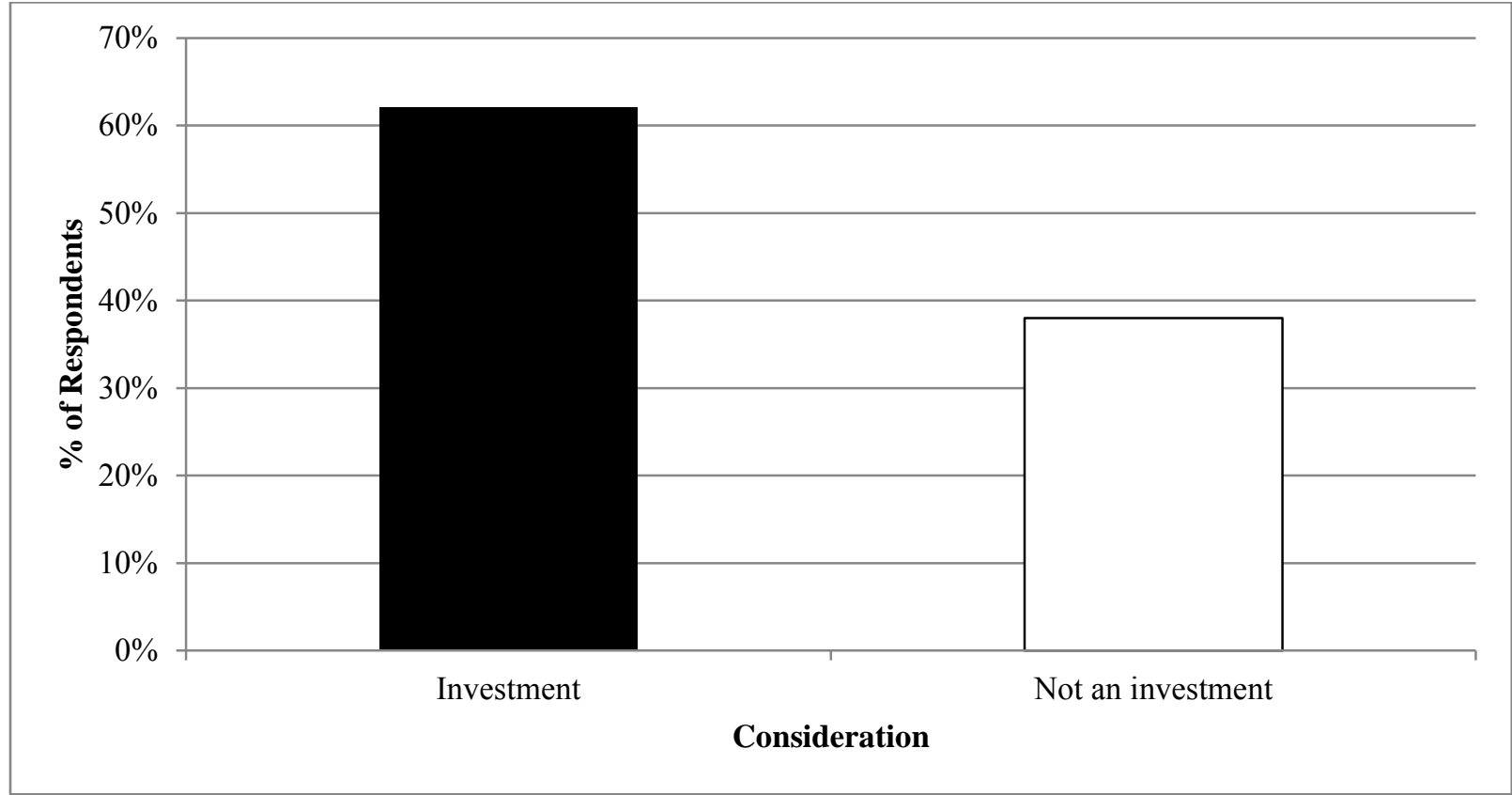

Figure 5.9: Whether respondents consider their property to be a monetary investment as reported by CE participants in West Virginia, $2011(\mathrm{n}=53)$.

It appears that a typical conservation easement landowner in West Virginia derives approximately $12 \%$ of their annual income from the land (Table 5.2). In comparison, the average West Virginia farmer derives about $10 \%$ of their yearly salary from the property (Hatton 2011).

Table 5.2: Percentage of income derived from the land as reported by CE participants in West Virginia, 2011.

\begin{tabular}{|c|c|}
\hline Description & Mean \\
\hline Percentage of income derived from the land & $12.47 \%$ \\
\hline
\end{tabular}


Potential motivations for participation are located in Table 5.3. The questions on the survey were ordinal in nature. Results showed these landowners to have a strong personal connection to their land. They also felt as though property ownership in West Virginia provided them with a sense of place. Being an active citizen in the community appears relatively important to this demographic, but their perception of American environmental policy effectiveness was only moderate.

Table 5.3: Potential motivations for enrollment as reported by CE participants in West Virginia, 2011.

\begin{tabular}{|l|c|}
\hline \multicolumn{1}{|c|}{ Description } & \multicolumn{1}{c|}{$\begin{array}{c}\text { Mean Likert Score } \\
\text { (1 to 4; where 1 = none and 4 = a lot })\end{array}$} \\
\hline Personal connection to the land & 3.79 \\
\hline Land in WV provides sense of place & 3.77 \\
\hline Owner perception of civic responsibility importance & 3.60 \\
\hline Perception of US environmental policy effectiveness & 2.62 \\
\hline
\end{tabular}

In addition to potential motivations, easement participants were asked about potential barriers (Table 5.4). These questioned were ranked with likert values as well. Two questions: 1) whether the landowner believed his/her property had conservation value; and 2) importance of conservation easements to West Virginia's landscape; had identically high averages (3.63). Respondents were knowledgeable about conservation easements in general, which is illustrated by their mean score of 3.51. They had also been introduced to a fair amount of information about the alternative; recording an average of 3.28. Finally, whether or not the individual was concerned with the easement infringing on their property rights had an expected low mean likert value (1.83). 
Table 5.4: Potential barriers for enrollment as reported by CE participants in West Virginia, 2011.

\begin{tabular}{|l|c|}
\hline \multicolumn{1}{|c|}{ Description } & $\begin{array}{c}\text { Mean Likert Score } \\
\text { (1 to 4; where 1 = none and 4 = a lot) }\end{array}$ \\
\hline Value of property for conservation & 3.63 \\
\hline Importance of CE to WV's landscape & 3.63 \\
\hline Knowledge of CE & 3.51 \\
\hline Exposure to info about CE & 3.28 \\
\hline Concern about CE infringing on PPR & 1.83 \\
\hline
\end{tabular}

West Virginia landowners that have conservation easements on their property appear to hold the importance of conservation and preservation topics in a rather lofty regard (Table 5.5). All mean likert scores, ranging from 1-4, were above three within this grouping. Protecting wildlife habitats were the most important issue to the landowners. The importance of conservation (managed landscapes) and preservation (unaltered landscapes) also ranked high in respondent priority. Aesthetics and historic preservation came in fourth and fifth but were still prevalent. Finally, protecting land for public recreation or education came in last but also has an average above three.

Table 5.5: Importance of conservation and preservation topics as reported by CE participants in West Virginia, 2011.

\begin{tabular}{|l|c|}
\hline \multicolumn{1}{|c|}{ Description } & $\begin{array}{c}\text { Mean Likert Score } \\
\text { (1 to 4; where 1 = Not and 4 = Very) }\end{array}$ \\
\hline Wildlife habitat & 3.77 \\
\hline Land conservation & 3.75 \\
\hline Land preservation & 3.75 \\
\hline Scenic enjoyment & 3.65 \\
\hline Historic preservation & 3.23 \\
\hline Public recreation or education & 3.10 \\
\hline
\end{tabular}


When asked about their amount of trust in the organizations that hold conservation easement agreements, the scores were moderate to high (Table 5.6). According to the mean likert scores it appears that conservation easement participating landowners have relatively more trust in non-governmental organizations. Government agencies were rated lower but not by a large amount.

Table 5.6: Perception of organization trustworthiness as reported by CE participants in West Virginia, 2011.

\begin{tabular}{|l|c|}
\hline \multicolumn{1}{|c|}{ Description } & $\begin{array}{c}\text { Mean Likert Score } \\
\text { (1 to 4; where 1 = Not and 4 = Very })\end{array}$ \\
\hline Trustworthiness of non-governmental organizations & 3.22 \\
\hline & 2.96 \\
\hline Trustworthiness of government agencies & \\
\hline
\end{tabular}

\subsubsection{Conservation Easement Participants}

The county in which the eased property is located was asked in order to view the distribution of participation. West Virginia's Resource Conservation and Development (RC\&D) state map was used for this analysis (USDA NRCS 2011). Each county was placed into one of the six regions (Figure 5.10). The areas are titled: Northern Panhandle, Little Kanawha, WesMon-Ty, Eastern Panhandle and the Mountain regions. 


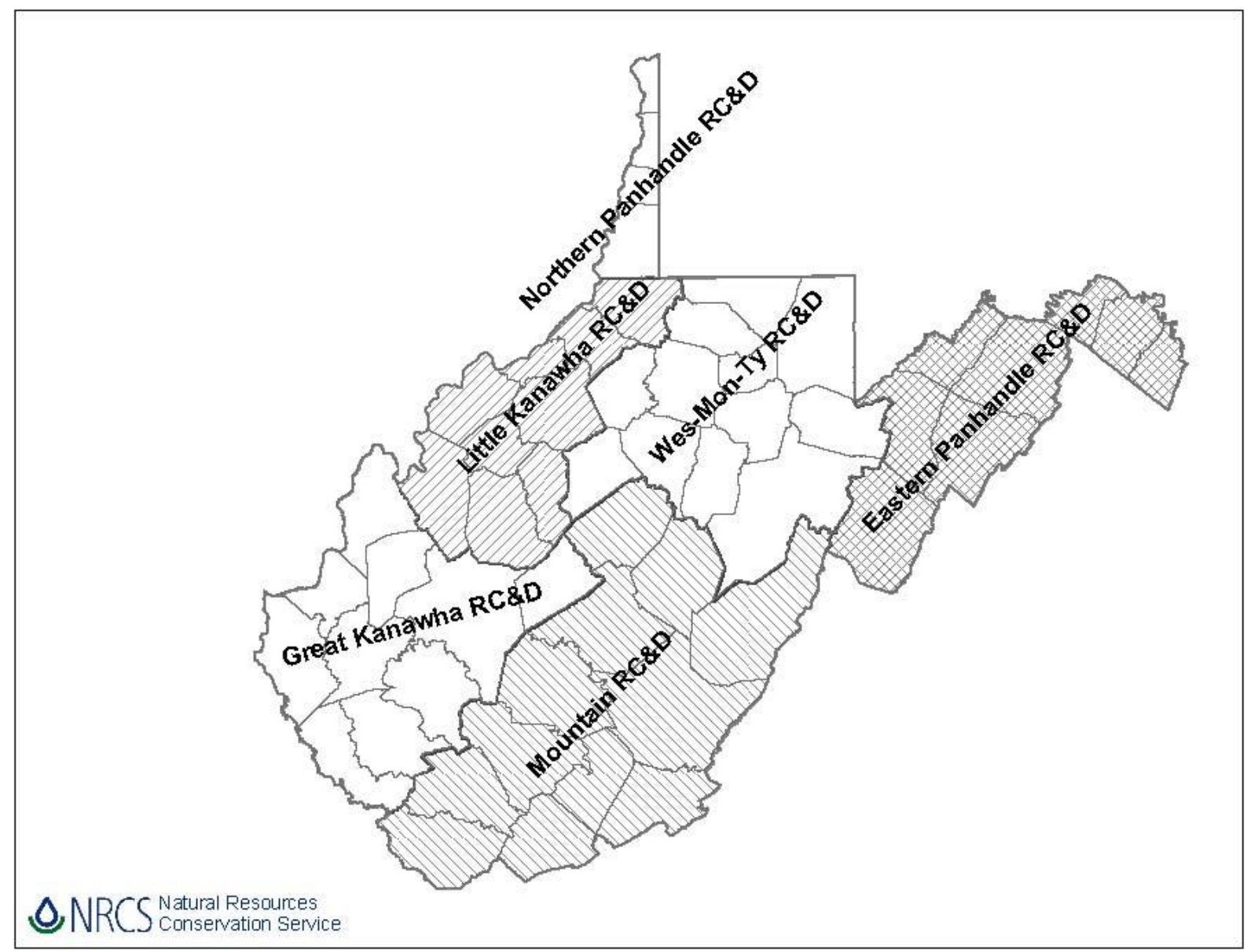

Figure 5.10: Resource Conservation and Development areas, West Virginia 2011.

There is high development pressure in the eastern panhandle of West Virginia (American Farmland Trust 2009); which is evident in Figure 5.11.This area of the study had a glaring majority of the easements (76.9\%). A large disparity then occurs in the residual categories, which have much fewer acquisitions. 


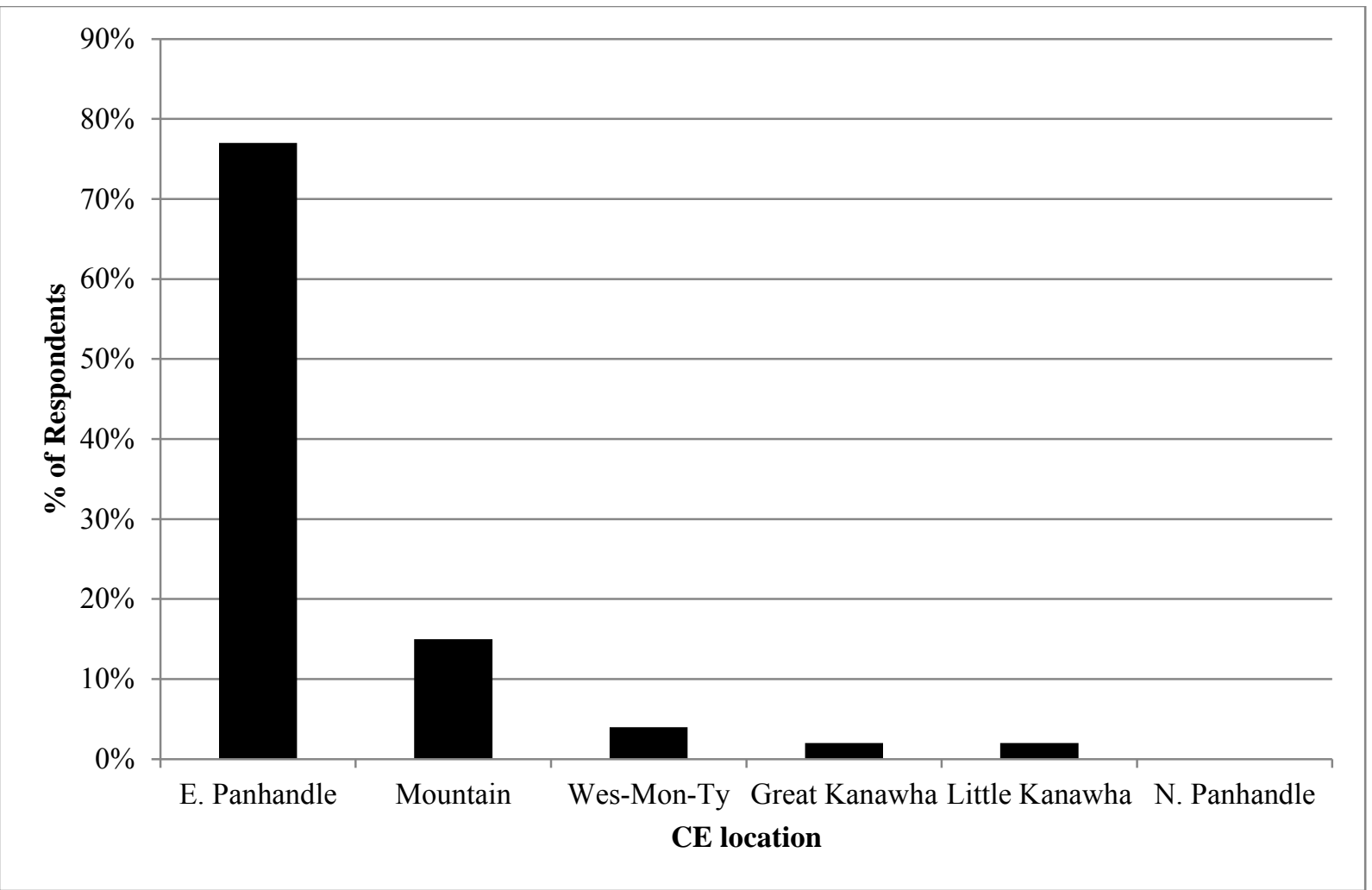

Figure 5.11: Location of conservation easement as reported by CE participants in West Virginia, $2011(n=52)$.

The landowners were then asked whether or not they were the individual who placed the conservation easement on the property (Figure 5.12). Almost all of the respondents were the landowners who had initiated the agreement. This is possibly a reflection of the recent increase in popularity and use of the alternative. 


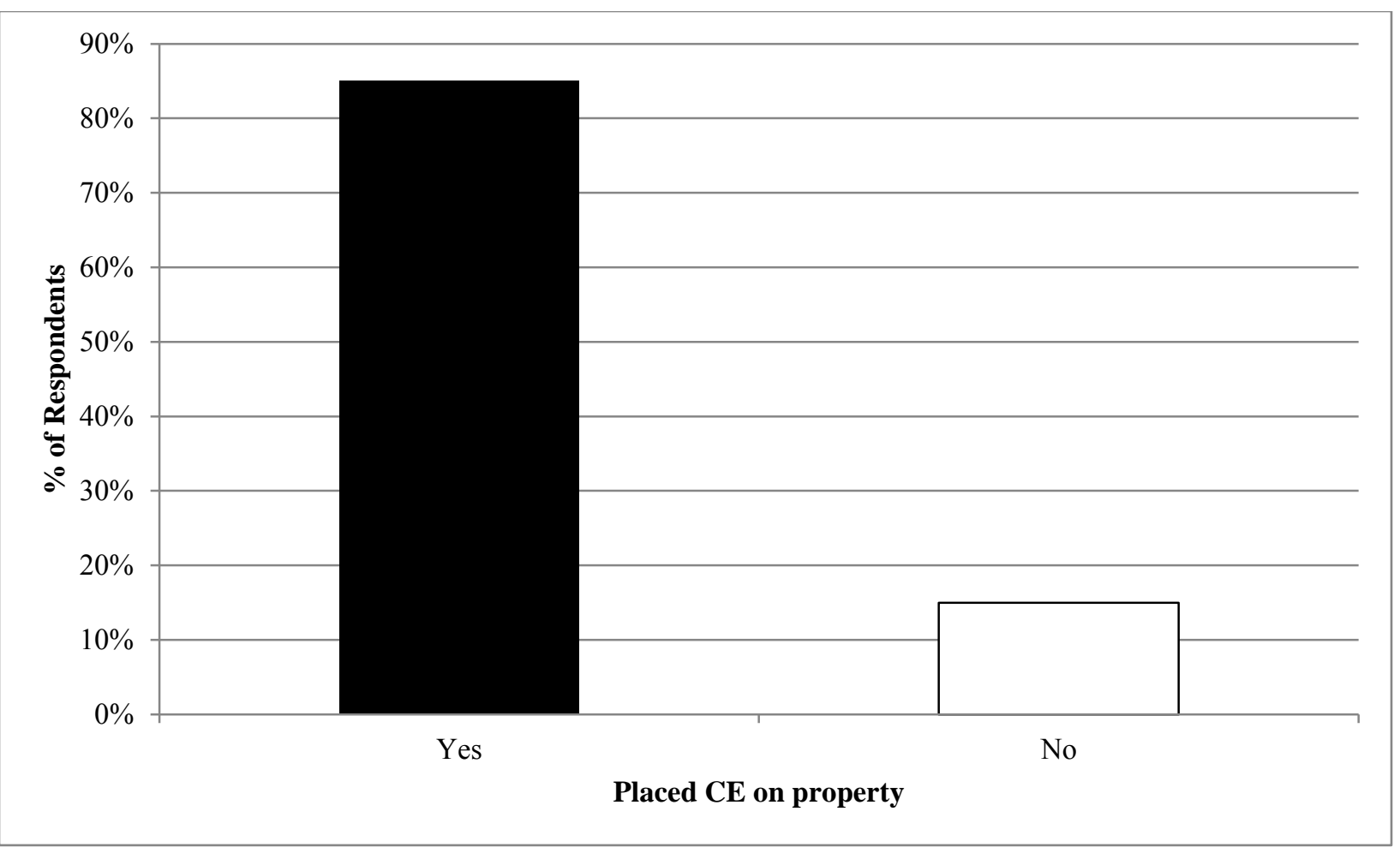

Figure 5.12: Whether or not the landowner placed the conservation easement on the property as reported by CE participants in West Virginia, $2011(n=53)$.

There were several different reasons for participation in a conservation easement program provided by the respondents (Figure 5.13). Preventing development was cited as the landowner's primary motivation the most $(32.7 \%)$. Preservation and conservation were second and third with $26.9 \%$ and $19.2 \%$ of the distribution, respectively. Financial incentives were next $(9.6 \%)$, followed by the category entitled "other" (e.g., save farm, protect natural spring, bought property under $\mathrm{CE}$ ) which recorded $7.7 \%$ of the distribution. Landowner personal connection to the property came in last with $3.8 \%$ of the responses. 


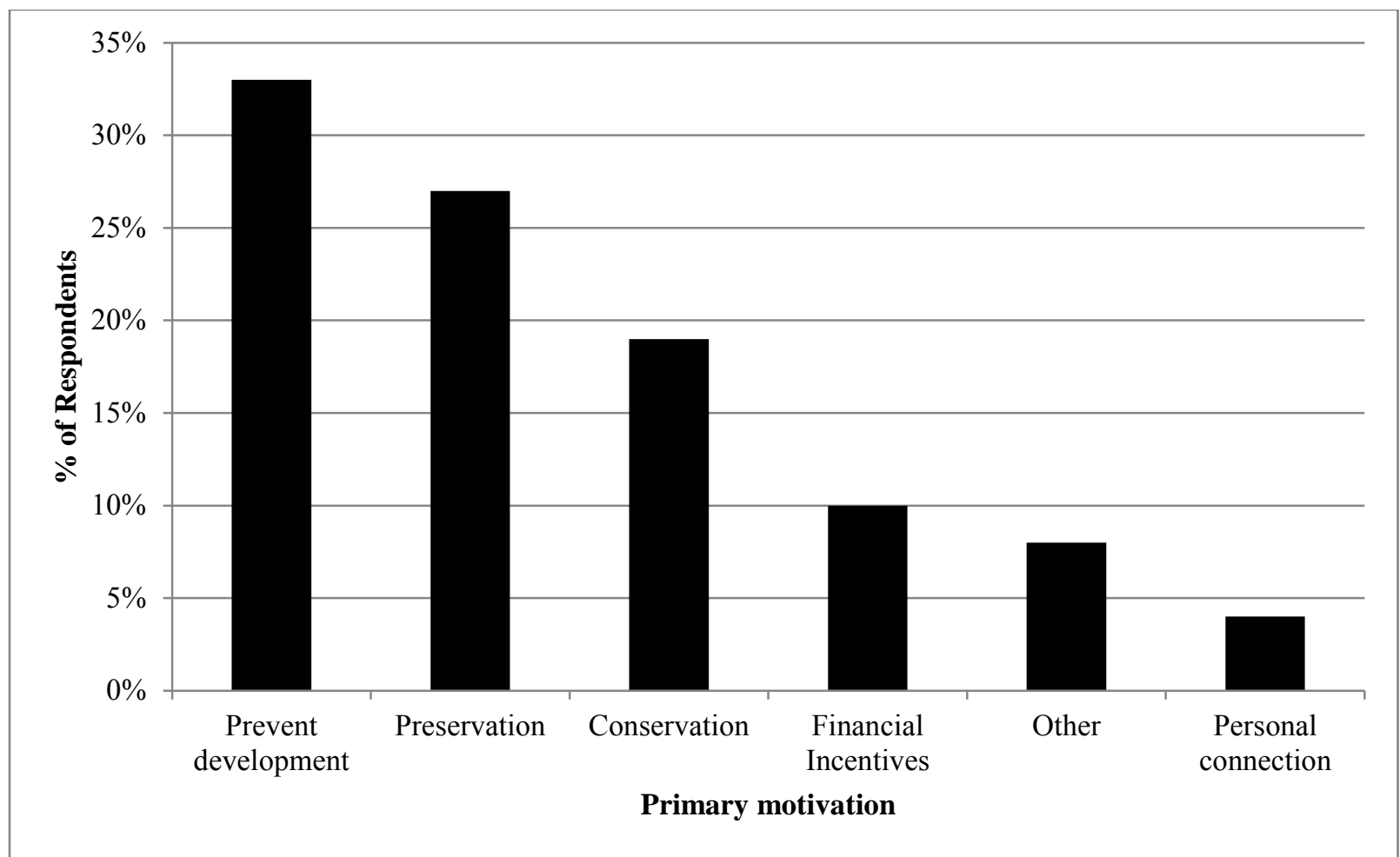

Figure 5.13: Primary motivation for placing a conservation easement on the property as reported by CE participants in West Virginia, $2011(\mathrm{n}=52)$.

It appears the most common method of exposure to the easement alternative here is nongovernmental organizations and informal communication (Figure 5.14). Several individuals read about easements in the literature; while many of the landowner's answered "other" (e.g., multiple sources) when asked where they learned about the option. 


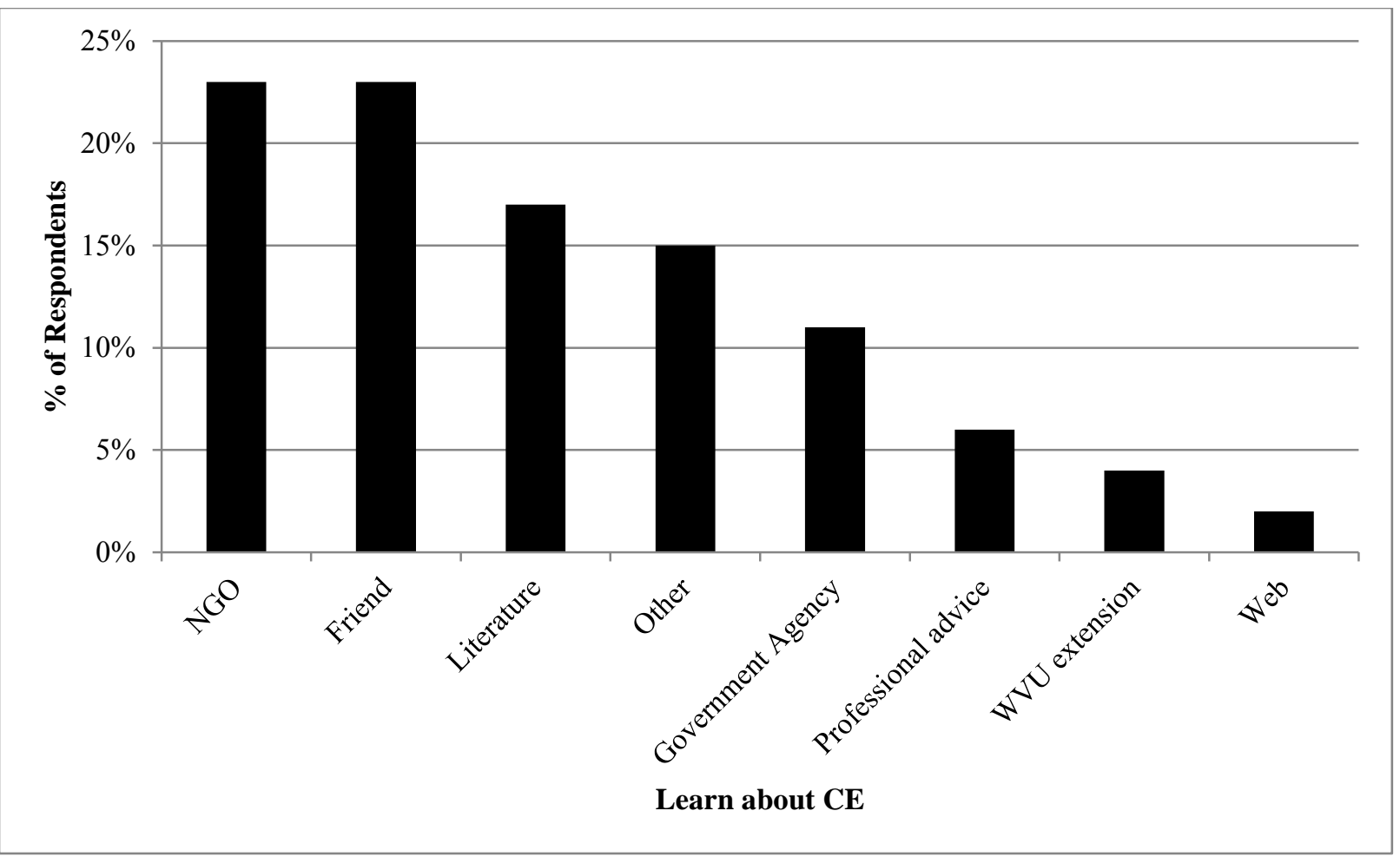

Figure 5.14: Method of exposure to conservation easements as reported by CE participants in West Virginia, $2011(\mathrm{n}=53)$.

There are three methods of payment with regard to the financial incentives and conservation easements (Figure 5.15). Donating the easement allows the landowner to deduct the entire valuation of said easement from his/her gross annual income. Bargain sale allows the landowner to accept a percentage of the endowment and then donate the rest for charitable deduction. Purchase is the third option and presents the landowner with the entire monetary value of the easement. Donation was the leading category for method of payment. 


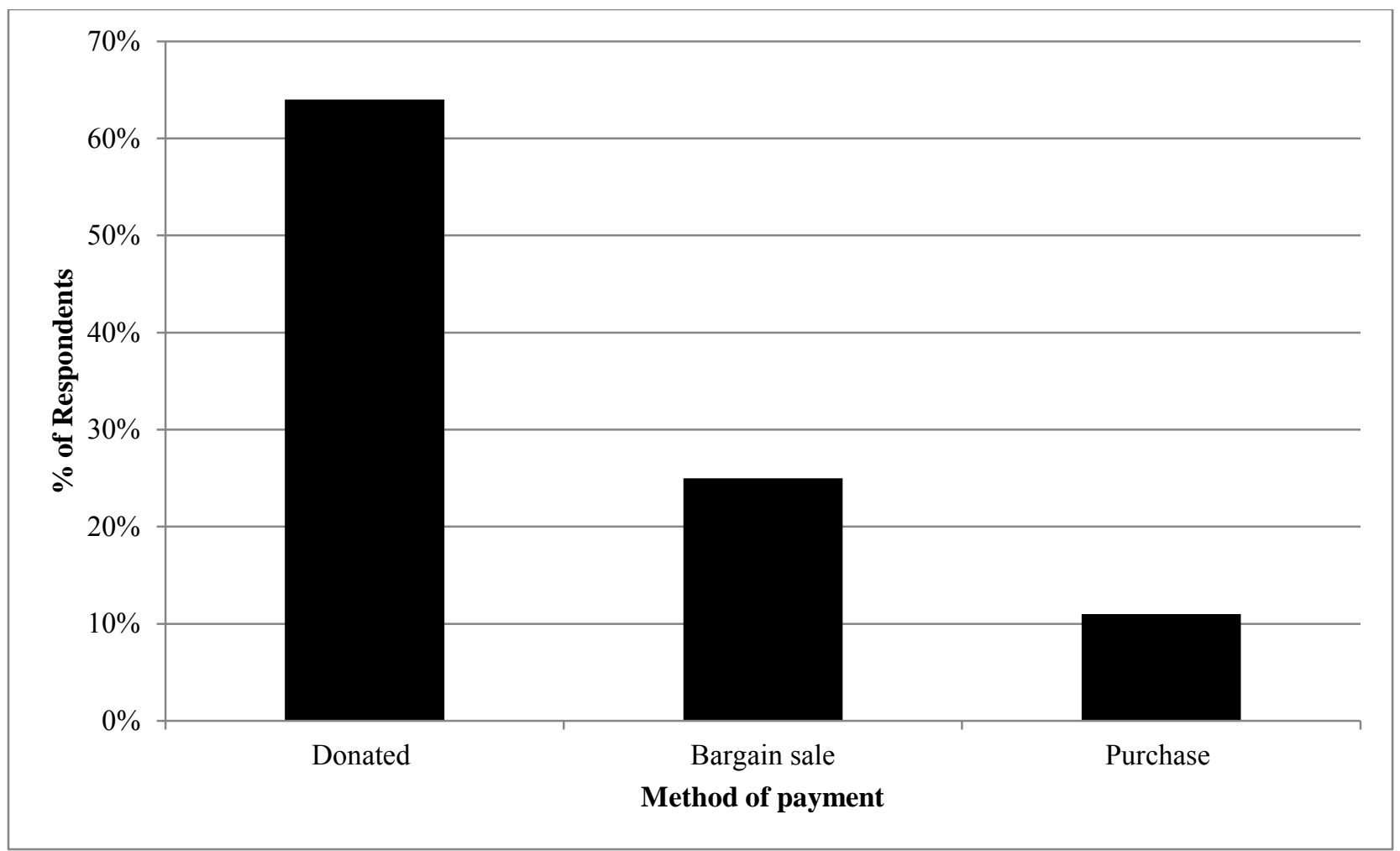

Figure 5.15: Method of payment chosen by the landowner as reported by CE participants in West Virginia, $2011(\mathrm{n}=52)$.

Length of time since placing restrictions on the property may provide further indication of the type of landowners participating in programs (Table 5.7). Respondents were asked, "What year was the conservation easement acquired?" Average length since easing the property was not long. This is likely another reflection of the revitalized popularity of the easement alternative. Table 5.7: Length of acquisition as reported by CE participants in West Virginia, 2011.

\begin{tabular}{|c|c|}
\hline Description & Mean \\
\hline Length of acquisition for CE (years) & 6.41 \\
\hline
\end{tabular}

Looking to differentiate between monetary and intrinsic values, participants were asked to rate the importance of three key issues; conservation, preservation and financial incentives (Table 5.8). These are central aspects to the alternative. The results showed that conservation was most important to respondents; while financial incentives were least. 
Table 5.8: Important aspects of conservation easements as reported by CE participants in West Virginia, 2011.

\begin{tabular}{|l|c|}
\hline \multicolumn{1}{|c|}{ Description } & $\begin{array}{c}\text { Mean Likert Score } \\
\text { Conservation (managed landscapes) }\end{array}$ \\
\hline Preservation (unaltered landscapes) & 3.64 \\
\hline Financial incentives & 3.56 \\
\hline
\end{tabular}

Private property restrictions are another essential, and often controversial, element to conservation easements (Table 5.9). Participants were asked to rate their level of agreement with restrictions on specific activities. There were six topics the respondents were asked to address, and the analysis revealed landowners believe easements too restrictive of additional structures the most. Participants did not feel as though the limits on forest management were too strict in relation to the other topics. Overall, the respondents did not feel like the easement was too prohibitive for good use of the property.

Table 5.9: Agreement level regarding restrictions as reported by CE participants in West Virginia, 2011.

\begin{tabular}{|l|c|}
\hline \multicolumn{1}{|c|}{ Description } & $\begin{array}{c}\text { Mean Likert Score } \\
\text { (1 to 4; where 1 = Strongly } \\
\text { disagree and 4 = Strongly agree) }\end{array}$ \\
\hline CE too restrictive of additional structures & 1.94 \\
\hline CE too restrictive of road building & 1.83 \\
\hline CE too restrictive of forestry activities (e.g., harvesting) & 1.81 \\
\hline CE too restrictive of recreational activity & 1.72 \\
\hline CE too restrictive of commercial activity & 1.68 \\
\hline CE too restrictive for good use of the property & 1.62 \\
\hline
\end{tabular}

Each of the participants were asked which organization held their conservation easement agreement (Figure 5.16). These answers were then categorized into three groups: government agencies, non-governmental organizations and co-held. Co-held meaning the agreement was authorized by a joint partnership comprised of both a government and non-governmental 
organization. The majority had agreements where a non-governmental organization was the grantee.

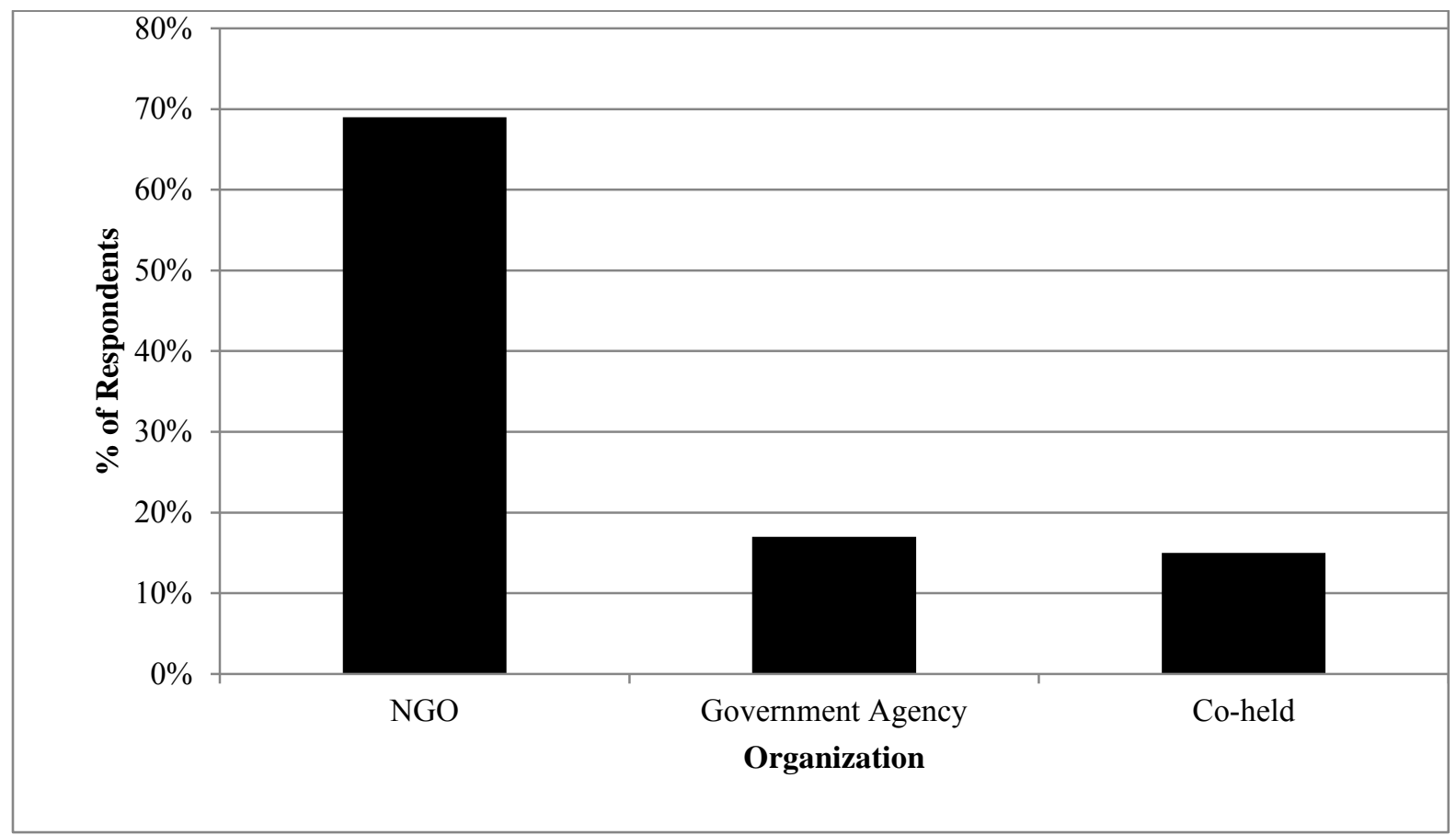

Figure 5.16: Conservation easement grantee as reported by CE participants in West Virginia, $2011(n=54)$.

Respondents were asked to provide the classification of their conservation easement (Figure 5.17). Most of the participants had preservation and farmland protection easements. Working Forest Conservation Easements (WFCE's) came in third.

The final question in the conservation easement participants section of the questionnaire inquired about landowner satisfaction with their conservation easement (Table 5.10). The ceiling for the likert score was four and overall contentment with the decision was relatively high. 


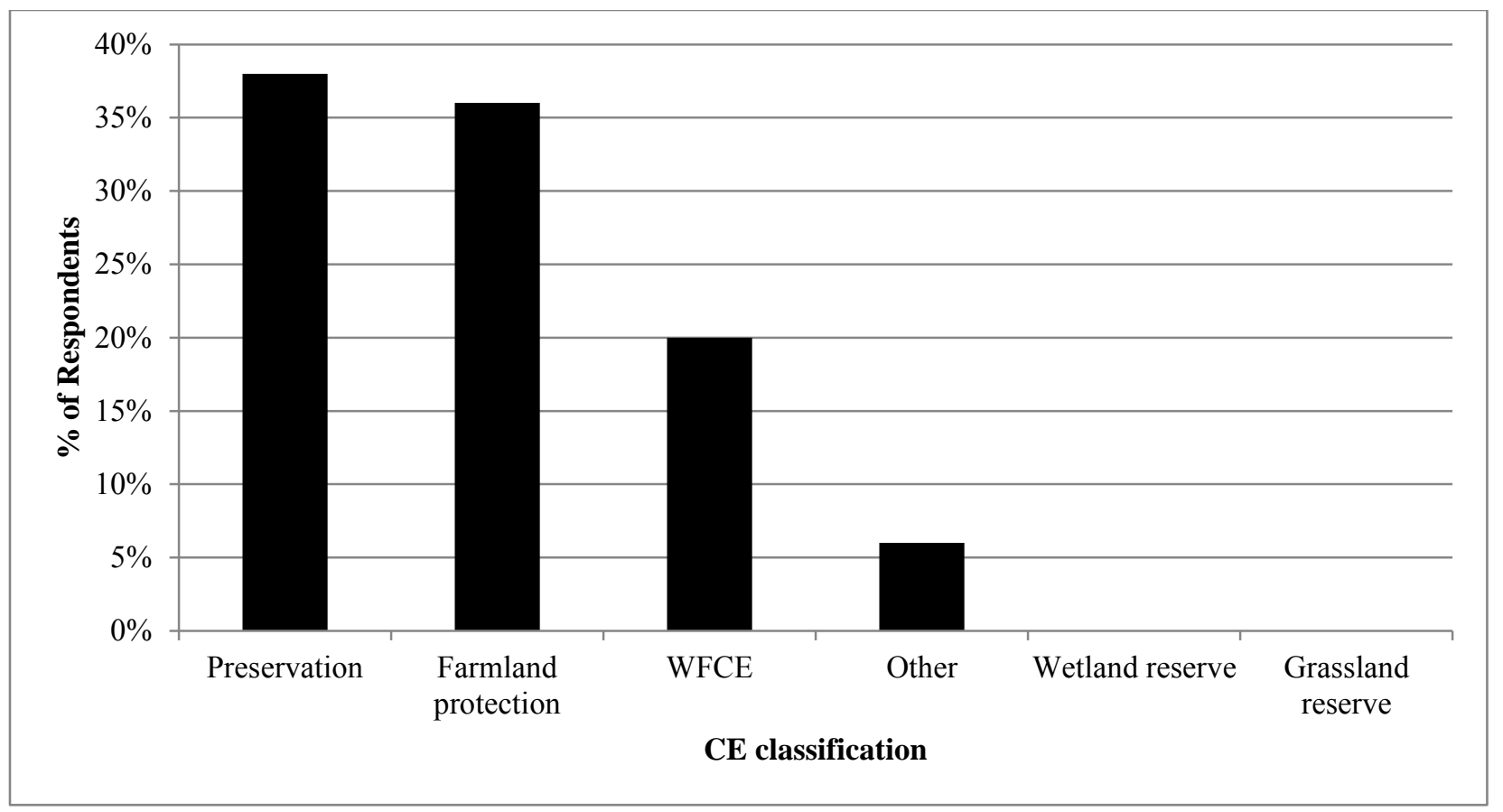

Figure 5.17: Easement classification as reported by CE participants in West Virginia, 2011 $(n=55)$.

Table 5.10: Amount of landowner satisfaction with their decision as reported by CE participants in West Virginia, 2011.

\begin{tabular}{|l|c|}
\hline & $\begin{array}{c}\text { Mean Likert Score } \\
(1 \text { to } 4 \text {; where } 1=\text { Not } \\
\text { Description }\end{array}$ \\
\hline Satisfaction with decision to place CE on property & 3.69 \\
\hline
\end{tabular}

\subsubsection{Demographics}

County of primary residence and location of the eased property is not always one in the same (Figure 5.18). Therefore, participants were asked about where they live. Much like the question regarding location of the eased property; West Virginia's Resource Conservation and Development's regional boundaries were utilized for analysis (USDA NRCS 2011). An “out-ofstate" category was included for individuals who do not live in West Virginia but have a conservation easement within the state. The Eastern Panhandle was home to the largest proportion of respondents (45.3\%); with many participants living "out-of-state" as well (26.4\%). 


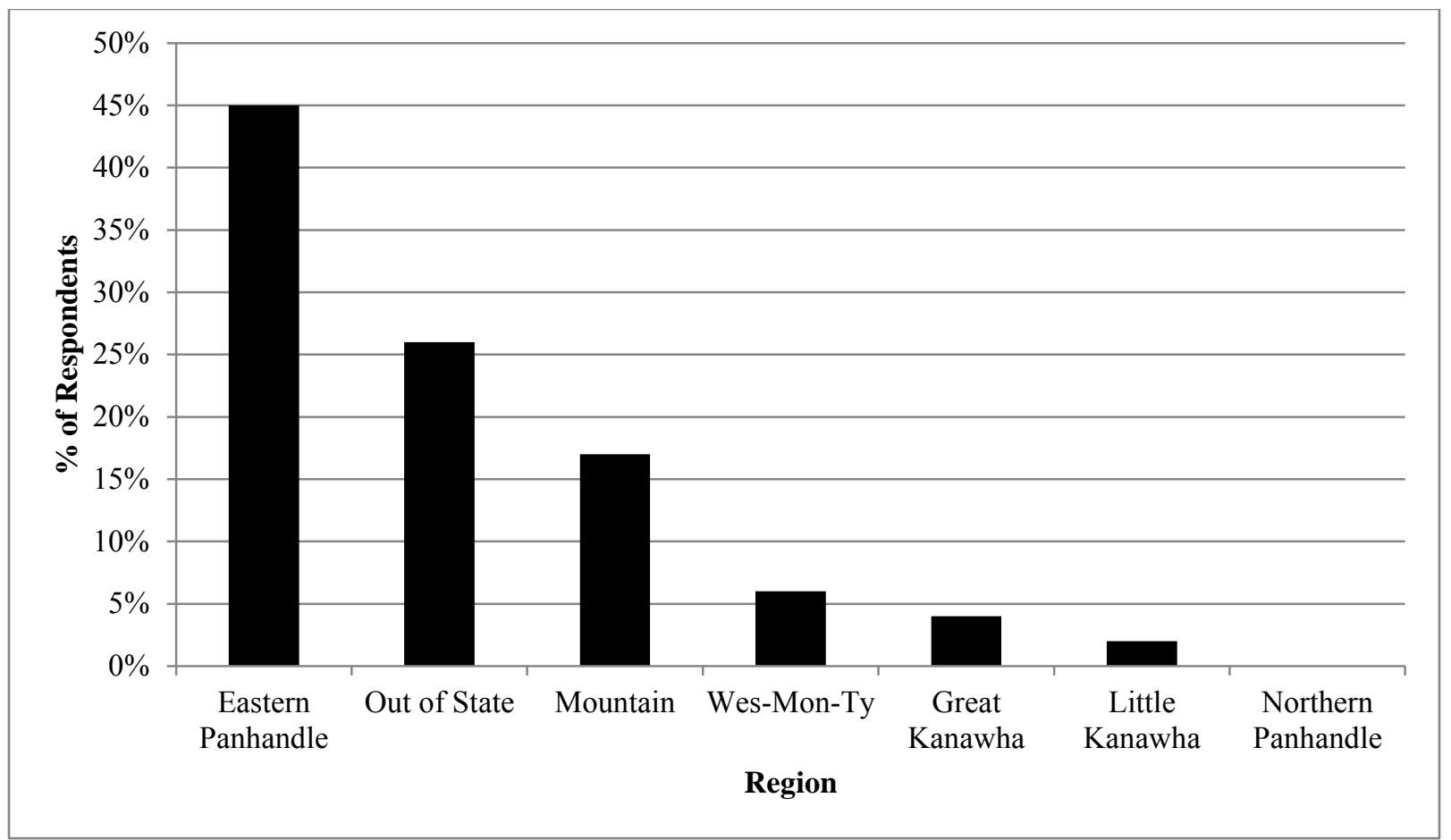

Figure 5.18: Region of primary residence as reported by CE participants in West Virginia, 2011 $(n=53)$.

Age and income were also included in the demographic portion of the survey (Table 5.11). Participants were typically in their sixties and fairly prosperous.

Table 5.11: Age and income as reported by CE participants in West Virginia, 2011.

\begin{tabular}{|l|c|}
\hline \multicolumn{1}{|c|}{ Description } & Mean \\
\hline Age (years) & 66.55 \\
\hline Income (dollars) & $140,446.81$ \\
\hline
\end{tabular}

When asked about their level of education, most of participants had a college education or higher (Figure 5.19); with most of those respondents being men (Figure 5.20). 


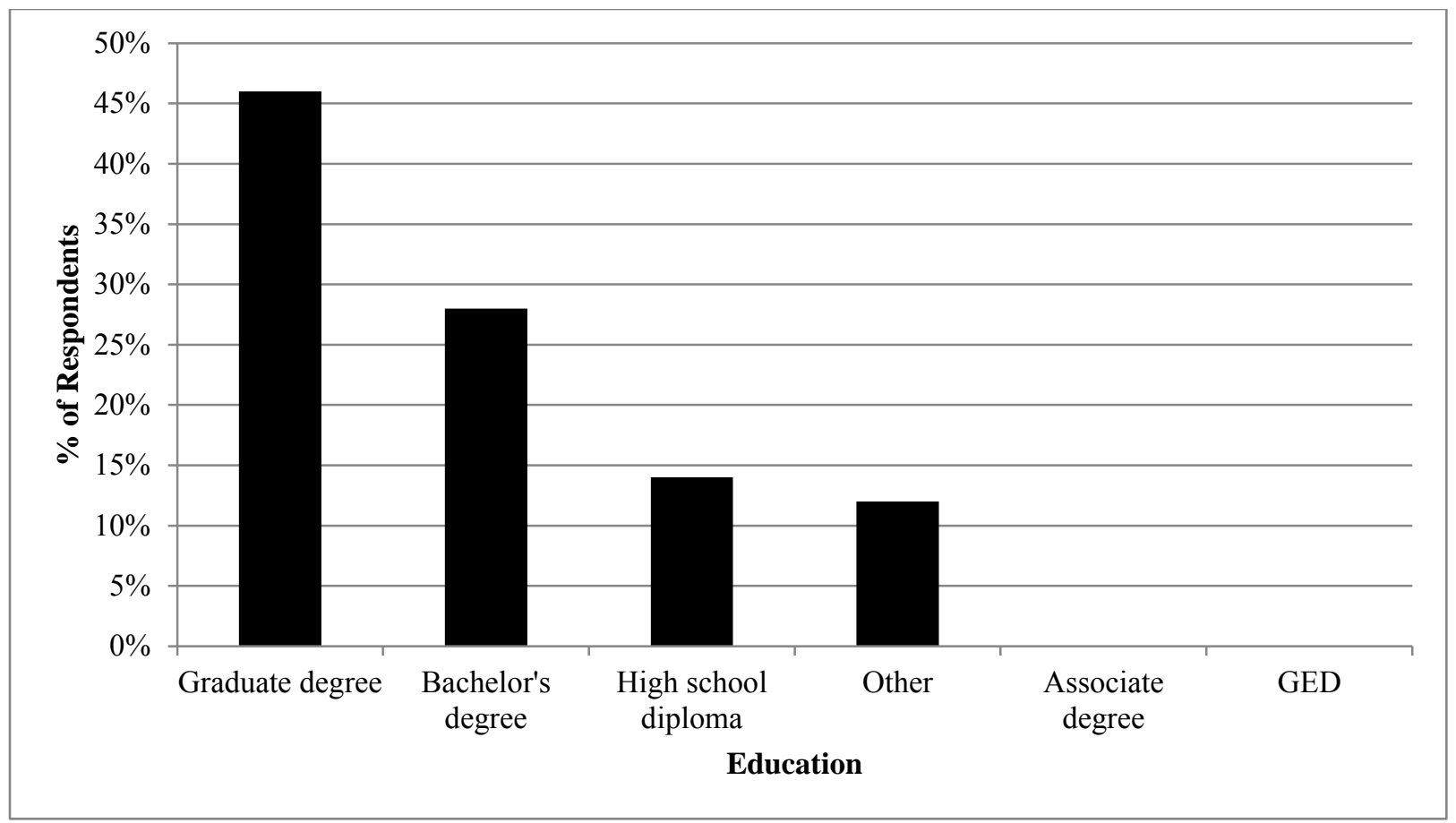

Figure 5.19: Level of education as reported by CE participants in West Virginia, $2011(\mathrm{n}=50)$.

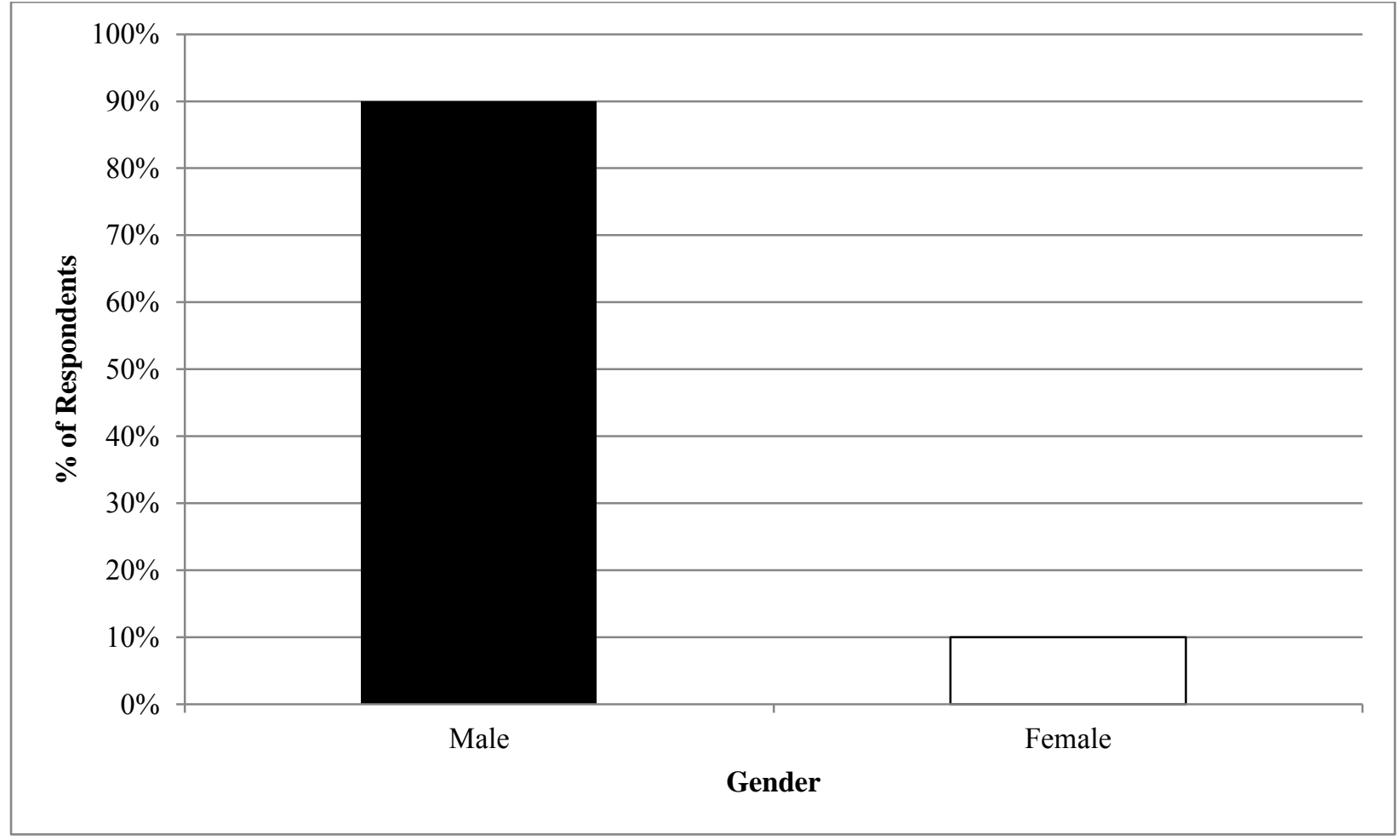

Figure 5.20: Gender as reported by CE participants in West Virginia, $2011(n=52)$. 


\subsubsection{Discussion}

There are thousands of private forestland owners in West Virginia; and these individuals own $10,418,000$ of the $12,007,000$ acres of the woodland (USDA Forest Service 2010c). However, conservation easement programs available to these landowners do not appear to be reaching their potential. West Virginia's Forest Legacy Program (FLP) acquired less than 800 acres in 2008 (USDA Forest Service 2009). In addition, the West Virginia Land Trust (WVLT) holds easements throughout the state but most of them are farmland (Young 2010). Results from this study shed further light onto this problem and support the notion that it will be necessary to target this demographic for participation in conservation easement programs.

Analysis of three key categories: 1) primary use for the eased property; 2) landowner perception of the most valuable aspect of the land; and 3) classification of the easements surveyed, are clear reflections of the research problem. For starters, primary use of the property had six categories; farmland was the most common use and timber production came in next to last. Merely $7.5 \%$ of the easement participants in this sample have commercial logging as their main activity. This is a troublesome fact in light of the 65.25 mean percentage of forest cover on the properties surveyed.

Landowner perception of the most valuable aspect of their land may possibly affect future decisions. There were seven property aspects for the respondents to choose from here; agriculture came in first again but timber dropped to last. Just 1.9\% of the demographic cited timber as the most important component of the land. Conservation easements are a flexible alternative so classifying the easements was imperative; from the six choices only four received responses (there were no wetland or grassland easements). In the remaining four categories, WFCE's came in second to last. Therefore, the assumption that forestland conservation easement 
programs in West Virginia are lacking in participation has some empirical validity and recruiting these individuals for enrollment is essential for the future.

A reoccurring theme throughout this research project; the eastern panhandle of the state is subject to much development pressure (American Farmland Trust 2009). Results show that the conservation easement alternative has reached this area of the state. Over three quarters of the easements in this study were located in the eastern panhandle region. Furthermore, $45.3 \%$ of the respondents live there; alluding to the fact that these individuals are more likely to ease their property. As mentioned previously, few of these conservation easements are being utilized for timber production. Therefore, not only is it recommended to focus on enrolling NIPF landowner's for programs, but targeting NIPF in the eastern panhandle of West Virginia is paramount.

"Financial returns is the most important reason for timbering" (Koontz 2001, p. 59). In West Virginia, landowner contentment with financial returns generated from a timber harvest has shown to be the most important factor related to their satisfaction level with the transaction (McGill et al. 2006). This analysis is concurrent with those findings regarding motivations for timber harvesting activity. Financial incentives were not the primary motivation; nor was timber the primary use for the majority of participants. Although more than half the respondents believed the property to be a financial investment, only $9.6 \%$ of the sample was motivated to enroll in a conservation easement for monetary purposes. Moreover, financial benefits were considered least important to respondents when compared to conservation and preservation. Koontz (2001) suggests that more profitable incentives might incite the sale of timber. Therefore it is recommended that in order to reach the NIPF demographic; an evaluation and possible reconfiguration of the current financial benefits is necessary. 
Degooyer and Capen (2004) studied the influence of conservation easements on forestry activity; they found $54 \%$ of their respondents had harvested since activating the easement. This indicates good forest management is possible with property that utilizes this alternative. In fact, they found landowners strongly rejected the idea that their easement was too restrictive of forestry related activities (Degooyer and Capen 2004). The results in this study were similar; participants were asked their level of agreement with the restrictions set on by the easement. All mean likert scores were low relative to the scale, meaning they did not believe the easement was too restrictive of the topics discussed in the questionnaire; notably commercial timber harvesting. Albeit not required, an easement document can be complimented by a management plan which specifies how activities on the eased land will occur (Mortimer et al. 2007). It is certainly advised that likely participants seek professional assistance when considering a conservation easement; but a recommendation for the future is that it be strongly advocated that NIPF have a forest management plan as well.

As mentioned earlier, monetary benefits are positively correlated to forestry. Landowners who undertake activities such as timbering, development, farming, haying and grazing for financial gain typically have lower income, less education and are older individuals that have larger tracts of land which provide income (Koontz 2001). Analysis of easement participating landowners in West Virginia inversely reflects this sentiment. Three quarters of the sample were: 1) the individual who placed the conservation easement on the land; and 2) not concerned with their ability to pay the current property taxes. Furthermore, their highest scoring potential motivators were personal connection to the land, and land ownership in West Virginia providing them with a sense of place; both intrinsic values. Average annual income for the respondents showed apparent affluence and $74 \%$ had a bachelor's degree or higher. One possible avenue that 
may increase enrollment by NIPF would be to focus recruitment toward the demographic inclined to actively manage their forest resources.

A salient point is that West Virginia landowners have diverse and multiple objectives. For example, participants in this study felt wildlife habitat, conservation, preservation, scenic enjoyment, historic preservation and public education/recreation were all important. This supports the assumption that conservation easements are a fitting alternative because of their ability to achieve several landowner goals. Moreover, these results further support that sentiment by the overall landowner satisfaction with their decision to participate in a conservation easement. These findings can possibly provide helpful information toward increasing West Virginia NIPF enrollment to the point where, "the typical landowner with a conservation easement is happy with that easement, has multiple management objectives including keeping the forest in a "natural condition" and harvesting wood products, and does not believe that easement hinders their freedom to manage the property in the way they want" (Degooyer and Capen 2004, p. 37). 


\section{Chapter VI: Conclusion}

"The outgrowth of conservation, the inevitable result, is national efficiency."

\section{Gifford Pinchot}

There are vast amounts of natural resources in the United States. Specifically, there are 751 million acres of woodland in America (USDA Forest Service 2007). Like the rest of the nation, West Virginia also has a plethora of renewable resources. The state has 12 million acres of forests which cover $78 \%$ of the surface area (Griffith and Widmann 2003). These facts are clear evidence of the opportunity for good stewardship practices; but opportunities are often accompanied by challenges. NIPF landowners have 423 million acres of the woodland nationwide (USDA Forest Service 2007). Furthermore, West Virginia has 251,000 NIPF landowners who hold approximately 10 million acres of the state's forestland (USDA Forest Service 2010c). Therefore, it is necessary to utilize policy alternatives that have the ability to take advantage of the opportunity in light of the challenges.

One possible solution is conservation easements. "An easement keeps property in private hands and on the tax rolls, and it protects the specific conservation values of a property according to the wishes of the individual landowner and easement holder" (Byers and Ponte 2005, p. 9). Conservation easements have had local and national impact; government and nongovernmental organizations along with various joint partnerships have made the alternative available to landowners. In fact, there are over 5 million acres of land conserved by 17,847 easements held by independent agencies in the U.S. (Byers and Ponte 2005), and the Forest Legacy Program (FLP) has protected 1,855,222 acres nationally (USDA Forest Service 2010a). Despite the 17,750 acres of land eased in West Virginia (The Nature Conservancy 2010), there is not an abundance of participation in these easement programs by NIPF landowners. Most of the 
easements held by the West Virginia Land Trust (WVLT) are farmland (Young 2010). The Land Trust of the Eastern Panhandle (LTEP) only has three (forested) easements (Smith 2010) and the WV FLP did not acquire acreage in 2009 (USDA Forest Service 2010c). This study provides information about NIPF landowner motivations for enrollment, their perceptions of the easement alternative and attributes of likely participants which may help increase participation.

Results from Chapter III reaffirmed the legitimacy of the Uniform Conservation Easement Act (UCEA) as an efficient tool for protecting private land, and its natural resources, from development. A legislative template for the West Virginia Conservation and Preservation Act, the UCEA (an inducement policy design type) was evaluated against three other alternatives: 1) no policy change (a regulatory policy design); 2) privatization; and 3) education. Comparisons were made in a decision matrix, a method commonly utilized in policy analyses. Three criterion measured the outcomes: 1) effectiveness; 2) administrative feasibility; and 3) ethics. The UCEA was the only policy instrument that received positive marks in each category. Thereby indicating continued usage of the act to be the best avenue for conservation on privately owned land.

Results, as discussed in Chapter IV, correlate well with the conclusions of previous research which claims that many influential factors affect private forest landowner decision making (Fortney et al. 2011; Kaetzel et. al 2009; Joshi and Arano 2009). NIPF with timber production as their primary use are willing to consider a forest conservation easement program; and as acreage, forest cover and development pressure increase, so does their likelihood to participate. Underlying motivations proved important as well. Individuals who felt inherently connected to their property, which in turn provided them with a sense of place, were more 
willing to enroll. These predictors are possibly associated with a rural upbringing, family heritage on the land and the desire to transfer rights to future generations.

There was also an apparent conservation ethic factoring into the decision making process. Landowners who felt conservation, preservation, protecting wildlife habitats, scenery and places for public education and recreation are likely applicants. However, even though conservation and preservation topics were motivating individuals, there was still evidence of potential barriers. Lack of information and apprehension toward restrictions are deterrents to participation. Landowners willing to enroll had a better understanding of the conservation easement alternative. This familiarity likely led these respondents to be less concerned with the easement infringing on their property rights.

Results also showed newer landowners are more inclined to ease their woodland. These individuals may have more long term goals for the land. Financial returns may be one of those objectives. If the landowner is dependent on the property and concerned with their ability to pay the property taxes they are likely to participate, especially if they perceive government and nongovernmental organizations to be trustworthy institutions. Despite all this, landowners are considerably less likely to enroll if they believe their most valuable returns will be realized from their development rights.

According to this study, a likely NIPF participant profile in West Virginia would be a well-educated and slightly younger landowner that has a relatively larger salary. It is a wellknown fact that the eastern panhandle of West Virginia has a high level of development pressure (American Farmland Trust 2009). An actuality supported by the results in this study, showing individuals living and owning woodland in this region being much more likely to enroll in a forest conservation easement program. Providing such information to program professionals may 
help improve initiatives. Increasing the visibility of the conservation easement alternative can also bring better understanding and dissolve common misinterpretations.

Chapter V examined results which provided further insight into the landowners who are participating in conservation easement programs. The majority of each parcel had forest cover, while farmland was cited as the primary use and most valuable aspect of the property for most respondents. Timber was significantly less in both categories. Preservation and farmland protection were the most frequent types of conservation easements and preventing development was the primary motivation for easing the property. The majority of respondents had made the decision to place the easement on the land, meaning their responses were direct insights of motivational factors toward participation. Most were not concerned with their ability to pay the current property taxes, an indication of affluence.

Greater than half of the respondents were first generational landowners and the majority showed interest in handing the property down to another generation. These individuals were mostly raised and currently living in a farm setting. Many respondents believed the land to be a monetary investment but were not deriving a large portion of their income from the property. Personal connection to the land was also a prevalent motivator toward enrollment. Furthermore, participants were definitively conscious about the alternative; showing they had encountered a wealth of information about conservation easements. This likely expounded potential barriers to enrollment such as rights infringement and organizational distrust.

Participants believed protection of wildlife habitat to be the cardinal issue with regard to the specified conservation and preservation topics, but conserving managed landscapes was the most important aspect of the easement to these individuals. Respondents did not feel as though the agreement was too restrictive for good use of the property. This is a finding which furthers 
the notion that easements are well suited for commercial activity. Overall, participating landowners in this study were satisfied with their decision to place the conservation easement on their property. Results indicate that the average conservation easement participant in West Virginia is a fairly prosperous older male with a bachelor's degree or further. As expected, most live and have eased property in the eastern panhandle region.

Protection of private forestland from development, fragmentation and parcelization is vital to West Virginia and the nation as a whole. It will be essential to increase NIPF landowner enrollment in conservation easement programs moving forward. By examining what affects landowner's decisions to place an easement on their land, this study has provided useful information that may increase NIPF participation. Specific recommendations are: 1) implementation of regional marketing (e.g., social marketing) to inform landowners of the multiple advantages, diminish the negative perception and address misconceptions; 2) to target the NIPF landowner demographic and advocate the incorporation of forest management plans with conservation easement agreements; 3 ) to give individuals with a high likelihood of participation (e.g., larger amounts of acreage, majority forest cover, located in developmentally sensitive areas) an elevated priority towards acceptance, particularly when affronted with funding constraints; and 4) to acutely explain the financial benefits to possible participants.

There is a need for continued research to assess the monetary incentives of conservation easements. In particular, how they might be improved to increase participation. Moreover, future research could evaluate how the monetary benefits might be integrated with timber harvesting activities to provide the landowner with substantial returns on a regular basis. This should all be done while remaining disciplined to conserving our natural resources and adhering to good stewardship practices. 


\section{References}

Agresti, A. 2002. Categorical Data Analysis (Second Ed.). John Wiley \& Sons, Inc: Hoboken, NJ. 710p.

Anderson, C.R. 1997. "Some Green for Some Green in West Virginia: An Overview of the West Virginia Conservation and Preservation Easements Act.” West Virginia Law Review, 99, 617.

American Farmland Trust. 2009. Farming on the Edge. Map. Accessed on April 17, 2011 at: http://www.littlekanawha.com/map_westvirginia300.jpg

Armsworth, P.R. and J.N. Sanchirico. 2008. "The Effectiveness of Buying Easements as a Conservation Strategy.” Conservation Letters, 1, 182-189.

Bardach, E. 2005. Appendix C. A Practical Guide for Policy Analysis: The Eightfold Path to More Effective Problem Solving (Second Ed.). New York: CQ Press, 133-140.

Barrett, T. J. and J. Diehl. 1988. The Conservation Easement Handbook: Managing Land Conservation and Historic Preservation Easement Programs. San Francisco, CA: Trust for Public Land. 269p.

Beliveau, L.S. 1993. "The Forest Legacy Program: Using conservation easements to preserve the Northern Forest.” Boston College Environmental Affairs Law Review, 20.

Best, C. 2002. “America's Private Forests: Challenges for Conservation.” Journal of Forestry, $100,14-17$.

Birch, T.W. 1994. The Private Forest-Land Owners of the United States. USDA Forest Service, Resource Bulletin NE-134. 183p.

Birch, T.W., D.G. Lewis and H. Fred Kaiser. 1982. The Private Forest-Land Owners of the United States. USDA Forest Service, Resource Bulletin WO-1. 61p. 
Blaine, T.W., F.R. Lichtkoppler and R. Stanbro. 2003. “An Assessment of Residents' Willingness to Pay for Green Space and Farmland Preservation Conservation Easements Using the Contingent Valuation Method (CVM).” Journal of Extension, August 2003, $41: 4$.

Bliss, John C., S. K. Nepal, R.T. Brooks Jr. and Max D. Larsen. 1997. "In the Mainstream: Environmental Attitudes of Mid-South Forest Owners.” Southern Journal of Forestry, 21, 37-43.

Butler, B.J., Tyrrell, M., Feinbert, G. VanManen, S., Wiseman, L. and S. Wallinger. 2007. "Understanding and Reaching Family Forest Owners: Lessons from Social Marketing Research.” Journal of Forestry, 348-357.

Butler, B.J., and E.C. Leatherberry. 2004. “America’s Family Forest Owners.” Journal of Forestry, 4-14.

Byers, E. and K.M. Ponte. 2005. The Conservation Easement Handbook. Washington, DC: Land Trust Alliance. 555p.

Cubbage, F.W., J. O’Laughlin and C.S. Bullock III. 1993. Forest Resource Policy. New York: John Wiley \& Sons. 562p.

DeGooyer, K. and D.E. Capen. “An Analysis of Conservation Easements and Forest Management in New York, Vermont, New Hampshire, and Maine.” Final Report. U of Vermont, 2004. Print.

DeLeon, P. 1997. Democracy and the Policy Sciences. Albany, NY: State University of New York Press. 160p.

Dillman, D.A., J.D. Smyth and L.M. Christian. 2009. Internet, Mail, and Mixed-Mode Surveys: The Tailored Design Method. Hoboken, NJ: John Wiley \& Sons. 499p.

Egan, A.F. 1997. "From Timber to Forests and People: A View of Nonindustrial Private Forest Research.” Northern Journal of Applied Forestry, 14, 189-193. 
Ernst, T. and G.N. Wallace. 2008. "Characteristics, Motivations, and Management Actions of Landowners Engaged in Private Land Conservation in Larimar County Colorado.” Natural Areas Journal 28, 109-120.

Faraway, J. 2006. Extending the Linear Model with R. Boca Raton, FL: Chapman \& Hall/CRC. $301 \mathrm{p}$.

Farmer, J.R. "Motivation for the Adoption of a Conservation Easement: A Midwestern Perspective.” Diss. U of Indiana, 2009. Print.

Farmer, J.R., H. Charles and B.C. Fischer. 2008. "Motivations for Participating in Conservation Easement Programs for Land Conservation." Research in Outdoor Education, 9, 112114.

Fishburn, I.S., P. Kareiva, K.J. Gaston, K.L. Evans and P.R. Armsworth. 2009. "State-Level Variation in Conservation Investment by a Major Nongovernmental Organization." Conservation Letters, 2, 74-81.

Forest Research. 2010. Accessed on May 4, 2010 at: http://www.forestry.gov.uk/fr/infd-5uwjwz

Fortney, J., Arano, K.G., and M. Jacobson. 2011. “An Evaluation of West Virginia’s Managed Timberland Tax Incentive Program.” Forest Policy and Economics, 13, 69-78.

Fortney, J. "An Evaluation of the West Virginia Managed Timberland Tax Incentive Program.” Thesis. U of West Virginia, 2009. Print.

Frame, G. 2009. Conservation Easements Keep Working Forests Working. Accessed on April 7, 2011 at: http://northernwoodlands.org/articles/article/conservation easements keep_working_fore sts_working/

Gan, J., Onianwa, O., Schelhas, J., Wheelock, G., and M. Dubois. 2005. "Does Race Matter in Landowners' Participation in Conservation Incentive Programs?" Society and Natural Resources, 18, 431-445. 
Griffith, D.M., and R. H. Widmann, 2003. Forest Statistics for West Virginia: 1989-2000.

USDA Forest Service Northeastern Research Station Resource Bulletin NE-157. Accessed on April 9, 2011 at:

http://www.fs.fed.us/ne/newtown square/publications/resource bulletins/pdfs/2003/ne r b157.pdf.

Gustanski, J.A. 2000. Protecting the Land: Conservation Easements, Voluntary Actions, and Private Lands. In J.A. Gustanski and R.H. Squires, Protecting the Land: Conservation Easements Past, Present and Future (pp. 9-25). Washington DC: Island Press.

Hatton, J. 2011, April 19. Farm Bill Easement Program Specialist; United States Department of Agriculture, Natural Resource Conservation Service. (M. Oliver, Interviewer).

Jennings, B.M. and D.W. McGill. 2005. "Evaluating the Effectiveness of the Forest Stewardship Program in West Virginia: Ten-Year Assessment." Northern Journal of Applied Forestry, $22,236-242$.

Jennings, B.M., D.J. Magill, McGill, D.W. and J. Warren. 2003. "Patterns of Forest Land Participation in the West Virginia Forest Stewardship Program." $13^{\text {th }}$ Central Hardwood conference. 2002 April 1-3; Urbana, IL.

Johnson, R. and J. Monke. (2010). “What is the „Farm Bill'?”. Congressional Research Service. $1-7$.

Jones, B. D., F.R. Baumgartner and J.L.True 2007. Explaining Stability and Change in Public Policymaking. In P. A. Sabatier, Theories of the Policy Process (pp. 155-187). Boulder, Colorado: Westview Press.

Joshi, S. and K.G. Arano. 2009. "Determinants of Private Forest Management Decisions: A Study on West Virginia NIPF Owners." Forest Policy and Economics, 11, 118-125.

Kabii, T. and P. Horwitz. 2006. "A review of landholder motivations and determinants for participation in conservation covenanting programmes." Environmental Conservation 33, $11-20$. 
Kaetzel, B.R., D.G. Hodges, D. Houston and J.M. Fly. 2009. "Predicting the Probability of Landowner Participation in Conservation Assistance Programs: A Case Study of the Northern Cumberland Plateau of Tennessee." Southern Journal of Applied Forestry, 33, $5-8$.

Kelly, E.D. 2010. Community Planning: An Introduction to the Comprehensive Plan. Washington, DC: Island Press. 405p.

Kiesecker, J.M., T. Comendant, T. Grandmason, E. Gray, C. Hall, R. Hilsenbeck, P. Kareiva, L. Lozier, P. Naehu, A. Rissman, M.R. Shaw and M. Zankel. 2007. "Conservation Easements in Context: A Quantitative Analysis of Their Use by the Nature Conservancy." Frontiers in Ecology and the Environment, 5, 125-130.

Koontz, T.M. 2001. "Money Talks-But to Whom? Financial Versus Nonmonetary Motivations in Land Use Decisions." Society and Natural Resources, 14, 51-65.

Kraft, M.E. and S.R. Furlong. 2010. Public Policy: Politics, Analysis, and Alternatives. Washington, DC: CQ Press. 482p.

Land Trust Alliance. 2011. Accessed on July 10, 2011 at: http://www.landtrustalliance.org/about

McGill, D.W., Grushecky, S.T., Moss, S., Pierskalla, C. and A. Schuler. 2008. "Landowner Willingness to Engage in Long-Term Timber Leases in West Virginia, USA.” Small Scale Forestry, 7, 105-116.

McGill, D.W., Pierskalla, C.D., Jennings, B.M., Grushecky, S.T. and D. Lilly. 2006. "Landowner Satisfaction with Timber Harvesting on West Virginia Forest Stewardship Program Properties." Northern Journal of Applied Forestry, 23, 6-10.

Mehmood, S.R. and D. Zhang. 2001. "Forest Parcelization in the United States: A Study of Contributing Factors." Journal of Forestry, 99, 30-34.

Merelander, A.M., L. Huntsinger, G. Guthey and S.K. Fairfax. 2004. "Land Trusts and Conservation Easements: Who is Conserving What for Whom?" Conservation Biology, 18, 65-75. 
Mortimer, M.J., J.J. Richardson Jr., J.S. Huff and H.L. Haney Jr. 2007. “A Survey of Forestland Conservation Easements in the United States: Implications for Forestland Owners and Managers." Small Scale Forestry, 6, 35-47.

Nagubadi, V., K.T. McNamara, W.L. Hoover and W.L. Mills Jr. 1996. "Program Participation Behavior of Nonindustrial Forest Landowners: A Probit Analysis." Southern Agriculture Economics Association, 28, 323-336.

National Park Service. 2010. Accessed on May 4, 2010 at: http://www.nps.gov/frla/index.htm

Ostrom, E., R. Gardner and J. Walker. 1994. Rules, Games, \& Common-Pool Resources. Ann Arbor, MI: The University of Michigan Press. 369p.

Rilla, E. 2002. "Landowners, while pleased with agricultural easements, suggest improvements." California Agriculture, 56, 21-25.

R version 2.12.10. 2010. "The R Foundation for Statistical Computing.” Accessed on July 9 , 2010 at: http://cran.r-project.org/

Rissman, A.R., L. Lozier, T. Comendant, P. Kareiva, J.M. Kiesecker, M.R. Shaw and A. M. Merelander. 2007a. "Conservation Easements: Biodiversity Protection and Private Use." Conservation Biology, 21, 709-718.

Rissman, A.R., R. Reiner and A.M. Merelander. 2007b. "Monitoring Natural Resources on Rangeland Conservation Easements. Who's minding the easement?" Society for Range Management, 29, 21-26.

Roe, C.E. 2000. Use of Conservation Easements to Protect the Scenic and Natural Character of the Blue Ridge Parkway: A Case Study. In J.A. Gustanski and R.H. Squires, Protecting the Land: Conservation Easements Past, Present and Future (pp. 221-229). Washington DC: Island Press.

Ryan, R.L., D.L. Erickson and R. De Young. 2003. "Farmers' Motivations for Adopting Conservation Practices along Riparian Zones in a Mid-western Agricultural Watershed. Journal of Environmental Planning and Management, 46, 19-37.

Sabatier, P. A. 2007. Theories of the Policy Process. Boulder, Co.: Westview Press. 344p. 
Sader, S.A., K. Ross and F.C. Reed. 2002. "Pingree Forest Partnership: Monitoring Easements at the Landscape Level." Journal of Forestry, 100, 20-25.

Sampson, N., L. DeCoster. 2000. "Forest Fragmentation: Implications for Sustainable Private Forests." Journal of Forestry, 98, 4-8.

Saville, D. 2010, March 9. Previous board member for the West Virginia Land Trust. (M. Oliver, Interviewer).

Small, S.J. 2005. Tax Benefits of Easement Donations. In E. Byers and K.M. Ponte's, The Conservation Easement Handbook (pp. 80-99). Washington, DC: Land Trust Alliance.

Small, S.J. 2000. An Obscure Tax Code Provision Takes Private Land Protection into the Twenty-First Century. In J.A. Gustanski and R.H. Squires, Protecting the Land: Conservation Easements Past, Present and Future (pp. 55-66). Washington DC: Island Press.

Small, S.J. 1997. The Federal Tax Law of Conservation Easements $-4^{\text {th }}$ Ed. Washington, DC: Land Trust Alliance.

Smith, G. Land Trust of the Eastern Panhandle. Message to the author. 05 Jan. and 19 Oct. 2010. E-mail.

Stone, D. 2002. Policy Paradox: The Art of Political Decision Making. New York \& London: WW Norton \& Company. 428p.

The Nature Conservancy. 2010. Conservation Easements in West Virginia. Accessed on February 13, 2010 at: http://www.nature.org/aboutus/howwework/conservationmethods/privatelands/conservati oneasements/files/ce_wvirginia.pdf

United States Legislature. Cooperative Forestry Assistance Act of 1978 § 8001. "National priorities for private forest conservation." . Uniform Conservation Easement Act of $1981 \S 1$. "Definitions." 
. Uniform Conservation Easement Act of $1981 \S 6$. "Uniformity of Application and Construction."

USDA NRCS. 2011. Farm and Ranchlands Protection Program. Accessed on April 10, 2011 at: http://www.nrcs.usda.gov/programs/frpp/2010_easements/acres-and-dollars.html.

. Resource Conservation and Development. Accessed on March 9, 2011at:

http://www.wv.nrcs.usda.gov/partnerships/rcd/rc\&dfinal_rev_s.pdf

USDA Forest Service. 2010a. Forest Legacy Program. Accessed on May 6, 2010 at:

http://www.fs.fed.us/spf/coop/programs/loa/flp.shtml

. 2010b. West Virginia Division of Forestry Cooperative Forest Legacy Program:

Information Brief. Accessed on February 13, 2010 at:

http://www.wvforestry.com/Forest $\% 20$ Legacy\%20Program\%20Infomation\%20Brief.pdf

.2010c. West Virginia: State and Private Forestry Fact Sheet. Accessed on February

13, 2010 at: http://www.na.fs.fed.us/ra/factsheets/wv std.pdf.

. 2009. West Virginia State and Private Forestry Fact Sheet. USDA Forest Service.

. 2007. Forest Resources of the United States. A Technical Document Supporting the

Forest Service 2010 RPA Assessment. Washington, DC: USDA Forest Service, 19.

Wallace, G.N., D.M. Theobald, T. Ernst and K. King. 2008. "Assessing the Ecological and Social Benefits of Private Land Conservation in Colorado." Conservation Biology, 22, 284-296.

Weimer, D. and A. Vining. 1999. Policy Analysis: Concepts and Practice. Upper Saddle River, NJ: Prentice Hall. 486p.

West Virginia Land Trust. 2010. Accessed on February 13, 2010 at: http://www.wvlandtrust.org/coalition.html

Whyte Jr., W.H. 1959. “Securing Open Space for America: Conservation Easements.” Urban Land Institute, 36, 5, 7. 
Yanow, D. 1995. Editorial: Practices of Policy Interpretation. Policy Sciences, 111-126.

Young, C. West Virginia Land Trust. Message to the author. 13 Jan. 2010. E-mail.

Zinn, G.W. and J.T. Sutton. 1976. "Major Forest Cover Type Groups of West Virginia." West Virginia Forestry Notes, 3-6. 


\section{Appendix A: Questionnaires}

\section{Non-easement participant survey for West Virginia Forest Landowners, 2010:}

Thank you for participating in this study. Your answers will help in understanding land management decisions made by West Virginia residents. If you are uncomfortable with a question, feel free to skip it and move to the next. The information you provide will be kept confidential. Your time and effort is sincerely appreciated.

\section{PROPERTY INFORMATION}

Woodland is considered property that is more than 10 continuous acres. Most of the land is covered in trees, which includes new growth on recently harvested areas.

1. Are you a woodland owner in West Virginia? (Please only select one)

Yes No

If you are not a woodland owner, please send the survey back in the provided envelope. Thank you.

If you own more than one parcel of land, please answer the following questions with your largest West Virginia parcel in mind.

2. In what county is your woodland located?

3. What is the primary use of the land? (Please only select one)

Timber production

Farmland

Recreation
Scenic Quality

Residence

Other (Please Specify)

4. About how many acres do you own? Acres

5. Approximately, what percent has forest cover? $\%$

6. For your woodland property, what generation landowner are you? (Please only select one)

$\begin{array}{ll}\text { First } & \text { Fourth } \\ \text { Second } & \text { Not Sure } \\ \text { Third } & \end{array}$

What year did you acquire your property? 
7. Are you concerned with transferring property rights to future generations? (Please only select one)
_Y Yes
No

8. Are you concerned with your ability to pay the current property taxes? (Please only select one)
_Yes
No

9. About how far is your property from the nearest town or city?

Miles

10. About how far is your property from the nearest public lands? (e.g., national forests, national parks, state forests, state parks, etc.)

Miles

11. Were you raised on or near the land you own? (Please only select one)

Yes

\section{MOTIVATIONS AND PERCEPTIONS}

For the purpose of this survey, personal connection refers to how you feel about the property you own. Sense of place refers to your overall feelings about owning land in West Virginia.

12. Do you have a personal connection to your land? (Please only circle one)

$\begin{array}{cccc}\begin{array}{c}\text { Not } \\ \text { Connected }\end{array} & \begin{array}{c}\text { Slightly } \\ \text { Connected }\end{array} & \begin{array}{c}\text { Somewhat } \\ \text { Connected }\end{array} & \begin{array}{c}\text { Very } \\ \text { Connected }\end{array} \\ 1 & 2 & 3 & 4\end{array}$

13. Does owning land in West Virginia provide you with a sense of place? (Please only circle one)

Not at all

1
Slightly

2
Somewhat

3
Very much

4 
Conservation easements are contracts between landowners and agencies (i.e., government or nongovernmental organizations) that usually establish future use of the property forever. Development rights are typically donated or sold and not held again. The purpose of the agreement is to fulfill the goals of the landowner while maintaining the conservation values of the land. Conservation easements protect land for future generations while allowing owners to retain many private property rights and to live on and use their land with potential tax benefits. For woodlands or forest lands, a landowner may enroll the property in a forest conservation easement program to preserve the forest use of the property.

14. How would you rate the following questions pertaining to conservation easements?

\begin{tabular}{|c|c|c|c|c|}
\hline & \multicolumn{4}{|c|}{ (Please only circle one) } \\
\hline & None & A little & Moderate & A lot \\
\hline How much do you know about conservation easements? & 1 & 2 & 3 & 4 \\
\hline $\begin{array}{l}\text { How often have you been exposed to information regarding } \\
\text { conservation easements? }\end{array}$ & 1 & 2 & 3 & 4 \\
\hline & Not & A little & Somewhat & Very \\
\hline $\begin{array}{l}\text { How concerned are you that a conservation easement } \\
\text { would infringe on your private property rights? }\end{array}$ & 1 & 2 & 3 & 4 \\
\hline $\begin{array}{l}\text { How valuable do you consider your property } \\
\text { for conservation purposes? }\end{array}$ & 1 & 2 & 3 & 4 \\
\hline How important are conservation easements to WV's landscape? & 1 & 2 & 3 & 4 \\
\hline
\end{tabular}

15. How would you rate the trustworthiness of the following organizations?

\begin{tabular}{|lcccc|}
\hline & \multicolumn{3}{c|}{ (Please only circle one) } \\
Governmental agencies (e.g., USDA) & Not & A little & Somewhat & Very \\
Non-governmental organizations (e.g., TNC) & 1 & 2 & 3 & 4 \\
\end{tabular}

16. What do you think is the most valuable aspect of your property? (Please only select one)

Development rights

Timber

Agriculture

Recreation
Environment (endangered plants and animals) Scenery

Other (Please Specify) 
17. In what type of environment were you raised? (Please only select one)

\begin{tabular}{|c|c|c|}
\hline Rural forest & Farm & _Other (Please specify) \\
\hline Rural Non-forest & Suburb & \\
\hline Mining town & CCity & \\
\hline
\end{tabular}

18. In what type of environment do you live now? (Please only select one)

$\begin{array}{ll}\text { Rural forest } & \text { Farm }\end{array}$ _ Other (Please specify)

19. Approximately, what percentage of your income comes from the land? $\%$

20. Do you consider your property a monetary investment? (Please only select one)<smiles>C[As]=N</smiles>

21. How would you rate the importance of being an active citizen within your community and/or civic responsibility? (Please only circle one)

$\begin{array}{cccc}\text { Not } & \text { Slightly } & \text { Somewhat } & \text { Very } \\ \text { Important } & \text { Important } & \text { Important } & \text { Important } \\ 1 & 2 & 3 & 4\end{array}$

22. How would you rate the importance of the following topics pertaining to conservation and preservation?

\begin{tabular}{|lcccc|}
\hline & \multicolumn{5}{c|}{ (Please only circle one) } \\
& Not & A little & Somewhat & Very \\
Land conservation (managed landscapes) & 1 & 2 & 3 & 4 \\
Land preservation (unaltered landscapes) & 1 & 2 & 3 & 4 \\
Wildlife habitat & 1 & 2 & 3 & 4 \\
Public recreation or education & 1 & 2 & 3 & 4 \\
Historic preservation & 1 & 2 & 3 & 4 \\
Scenic Enjoyment & 1 & 2 & 3 & 4 \\
\hline
\end{tabular}


23. How would you rate the development pressure on or around your land? (Please only circle one)
None
Low
Medium
High
1
2
3
4

24. What is your perception of environmental policies in the United States? (Please only circle one)

$\begin{array}{cccc}\text { Very } & \text { Somewhat } & \text { Somewhat } & \text { Very } \\ \text { Ineffective } & \text { Ineffective } & \text { Effective } & \text { Effective } \\ 1 & 2 & 3 & 4\end{array}$

25. Would you ever consider enrolling your property in a forest conservation easement program?

Yes _ No

\section{DEMOGRAPHICS}

26. Which county is your primary residence located?

27. What is your age?

28. What education level have you received? (Please only select one)

_GED

High school diploma

Associate degree
Bachelor's degree

Graduate degree

Other (Please specify)

29. Approximately, what is your annual household income?

30. What is your gender?

Male

Female

31. Would you be willing to participate in a short follow-up phone interview?

If yes, then please provide a contact number 
32. Please feel free to use the following space for any comments or suggestions regarding the research topic or survey questionnaire.

Thank you for your participation. Please provide your physical address in the space below if you are interested in the survey results or additional information about conservation easements. 


\section{Easement participant survey for West Virginia conservation easement landowners, 2010:}

Thank you for participating in this study. Your answers will help in understanding land management decisions made by West Virginia residents. If you are uncomfortable with a question, feel free to skip it and move to the next. The information you provide will be kept confidential. Your time and effort is sincerely appreciated.

\section{PROPERTY INFORMATION}

If you own more than one parcel of land, please answer the following questions with your West Virginia conservation easement property in mind.

1. What is the primary use of the land? (Please only select one)

_ Timber production Farmland Recreation
_. Scenic Quality

_Residence Other (Please Specify)

2. About how many acres do you own? Acres

3. Approximately, what percent has forest cover? $\%$

4. For your eased property, what generation landowner are you? (Please only select one)

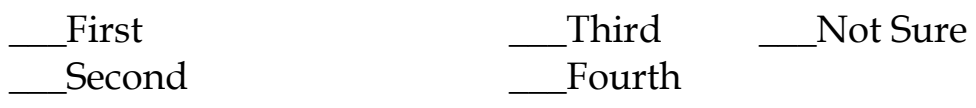

What year did you acquire your property?

5. Are you concerned with transferring property rights to future generations? (Please only select one)<smiles>C[AsH2]</smiles>

6. Are you concerned with your ability to pay the current property taxes? (Please only select one)<smiles>C[As]=[W]</smiles>

7. About how far is your property from the nearest town or city? Miles

8. About how far is your property from the nearest public lands? (e.g., national forests, national parks, state forests, state parks, etc.) Miles 
9. Were you raised on or near the land you own? (Please only select one)

Yes _ No

\section{MOTIVATIONS AND PERCEPTIONS}

For the purpose of this survey, personal connection refers to how you feel about the property you own. Sense of place refers to your overall feelings about owning land in West Virginia.

10. Do you have a personal connection to your land? (Please only circle one)

$\begin{array}{cccc}\begin{array}{c}\text { Not } \\ \text { Connected }\end{array} & \begin{array}{c}\text { Slightly } \\ \text { Connected }\end{array} & \begin{array}{c}\text { Somewhat } \\ \text { Connected }\end{array} & \begin{array}{c}\text { Very } \\ \text { Connected }\end{array} \\ 1 & 2 & 3 & 4\end{array}$

11. Does owning land in West Virginia provide you with a sense of place? (Please only circle one)

$\begin{array}{cccc}\text { Not at all } & \text { Slightly } & \text { Somewhat } & \text { Very much } \\ 1 & 2 & 3 & 4\end{array}$

Conservation easements are contracts between landowners and agencies that usually establish future use of the property forever. Development rights are typically donated or sold and not held again. The purpose of the agreement is to fulfill the goals of the landowner while maintaining the conservation values of the land.

12. How would you rate the following questions pertaining to conservation easements?

(Please only circle one)

\begin{tabular}{|c|c|c|c|c|}
\hline & None & A little & Moderate & A lot \\
\hline ow much do you know about conservation easements? & 1 & 2 & 3 & 4 \\
\hline $\begin{array}{l}\text { How often have you been exposed to information regarding } \\
\text { onservation easements? }\end{array}$ & 1 & 2 & 3 & 4 \\
\hline & Not & A little & Somewhat & Very \\
\hline vould infringe on your private property rights? & 1 & 2 & 3 & 4 \\
\hline $\begin{array}{l}\text { How valuable do you consider your property } \\
\text { or conservation purposes? }\end{array}$ & 1 & 2 & 3 & 4 \\
\hline important are conservation easemen & 1 & 2 & 3 & 4 \\
\hline
\end{tabular}


13. How would you rate the trustworthiness of the following organizations?

(Please only circle one)

Governmental agencies (e.g., USDA)

Not A little Somewhat Very

Non-governmental organizations (e.g., TNC)

1

23

4

$1 \quad 2 \quad 3$

4

14. What do you think is the most valuable aspect of your property? (Please only select one)

Development rights

Timber

Agriculture

Recreation
Environment (endangered plants and animals) Scenery Other (Please Specify)

15. In what type of environment were you raised? (Please only select one)

_ Rural forest

Rural Non-forest

Mining town
Farm

Suburb

City

16. In what type of environment do you live now? (Please only select one)

$\begin{array}{ll}\text { Rural forest } & \text { Farm } \\ \text { Rural Non-forest } & \text { Suburb } \\ \text { Mining town } & \text { City }\end{array}$

17. Approximately, what percentage of your income comes from the land? $\%$

18. Do you consider your property a monetary investment? (Please only select one)

- Yes $\quad$ No

19. How would you rate the importance of being an active citizen within your community and/or civic responsibility? (Please only circle one)

\section{Not Important}

2

Slightly
Important
2

\section{Somewhat Important}

3

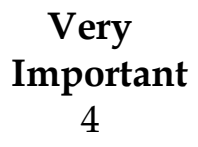


20. How would you rate the importance of the following topics pertaining to conservation and preservation?

\begin{tabular}{|lcccc|}
\hline & \multicolumn{3}{c|}{ (Please only circle one) } \\
Land conservation (managed landscapes) & Not & A little & Somewhat & Very \\
Land preservation (unaltered landscapes) & 1 & 2 & 3 & 4 \\
Wildlife habitat & 1 & 2 & 3 & 4 \\
Public recreation or education & 1 & 2 & 3 & 4 \\
Historic preservation & 1 & 2 & 3 & 4 \\
Scenic Enjoyment & 1 & 2 & 3 & 4 \\
\end{tabular}

21. What is your perception of environmental policies in the United States? (Please only circle one)

\section{Very Ineffective}

1

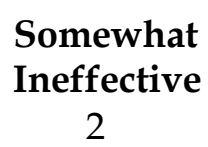

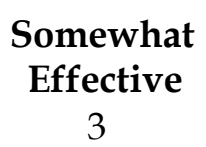

\author{
Very \\ Effective \\ 4
}

\section{CONSERVATION EASEMENT PARTICIPANTS}

For the purpose of this survey, the word conservation means land that is managed and the word preservation means land that is unaltered.

22. In what county is the conservation easement located?

23. Are you the owner that placed the conservation easement on the property? (Please only select one)
_Yes
No

24. What was the primary motivation for placing a conservation easement on the property? (Please only select one)

Financial incentives Prevent development Personal connection
Conservation (Managed landscapes) Preservation (Unaltered landscapes) Other (Please specify) 
25. How did you learn about conservation easements? (Please only select one)

Professional advice (e.g., lawyer or CPA)
_ Governmental agency
Non-governmental organization
WVU extension

Literature
Friend
Web
Other (Please specify)

26. What year was the conservation easement acquired?

27. How was the conservation easement acquired? (Please only select one)

Donated (Full value)

Bargain sale (Purchased at less than full value)

__Purchased (Full value)

28. Which organization(s) holds your conservation easement agreement?

29. How would you rate the importance of the following questions pertaining to conservation easements?

\begin{tabular}{|lcccc|}
\hline & \multicolumn{3}{c|}{ (Please only circle one) } \\
& Not & A little & Somewhat & Very \\
Financial Incentives & 1 & 2 & 3 & 4 \\
Conservation (managed landscapes) & 1 & 2 & 3 & 4 \\
Preservation (unaltered landscapes) & 1 & 2 & 3 & 4 \\
\hline
\end{tabular}

30. What is the classification of your conservation easement? (Please only select one)

Working forest conservation easement

Farmland protection easement

Preservation easement

Grassland reserve easement

Wetland reserve easement

Other (Please specify) 
31. Please indicate your level of agreement with the following statements regarding conservation easement restrictions.

(Please only circle one)

\section{Strongly \\ Disagree \\ Disagree Agree Agree}

Easement is too restrictive of commercial activity

$\begin{array}{llll}1 & 2 & 3 & 4 \\ 1 & 2 & 3 & 4 \\ 1 & 2 & 3 & 4 \\ 1 & 2 & 3 & 4\end{array}$

Easement is too restrictive for good use of the property

1

2

3

4

Easement is too restrictive for forestry activities (e.g., harvesting, prescribed burning, etc.)

1 2 3 4

32. How would you rate your satisfaction with the decision to place a conservation easement on your property? (Please only circle one)

\section{Not Satisfied}

1

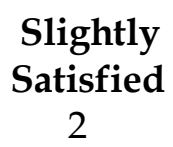

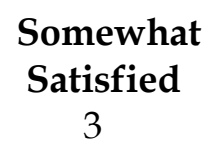

Very Satisfied

4

\section{DEMOGRAPHICS}

33. Which county is your primary residence located?

34. What is your age?

35. What education level have you received? (Please only select one)

GED
_ High school diploma
_ Associate degree
Bachelor's degree
Graduate degree
Other (Please specify)

36. Approximately, what is your annual household income?

37. What is your gender?

Male

Female 
38. Do you have any motivation for having a conservation easement not mentioned in this questionnaire? (Please use the space below)

39. Would you be willing to participate in a short follow-up phone interview?

If yes, then please provide a contact number

40. Please feel free to use the following space for any comments or suggestions regarding the research topic or survey questionnaire.

Thank you for your participation. Please provide your physical address in the space below if you are interested in the survey results or additional information about conservation easements. 


\section{Matt D. Oliver}

\section{Curriculum Vitae}

Office Address:

Permanent Address:

339 Percival Hall

3226 East $11^{\text {th }}$ St.

PO Box 6125

Anderson, IN 46012

Morgantown, WV 26506-6125

Cell: (765) 617-7841

molive10@mix.wvu.edu

mattdoliver@hotmail.com

\section{EDUCATION}

Master of Science in Forest Resource Management (2011)

West Virginia University-Division of Forestry and Natural Resources, Morgantown, WV.

Concentration: Forest Resource Policy

Thesis: An Evaluation of West Virginia's Non-Industrial Private Forest Landowner Participation in Conservation Easements

Chair: Dr. Kathryn G. Arano

GPA: $3.9 / 4.0$

Bachelor of Science in Criminal Justice and Criminology (2004)

Ball State University-Department of Criminal Justice and Criminology, Muncie, IN.

Major: Criminal Justice and Criminology

Minor: Religious Studies

GPA: $3.2 / 4.0$

\section{EMPLOYMENT}

\section{Graduate Research Assistant (2009-till date)}

West Virginia University-Division of Forestry and Natural Resources, Morgantown, WV.

Assisted and conducted research activities such as primary and secondary data entry and analysis.

\section{Shop Manager (2006-2008)}

Liberty House Utility Buildings-Asheville, NC

Responsibilities included supervision of twenty employees; maintaining inventory and managing construction of utility buildings while providing quality assurance for approximately 120 clients per month.

\section{Program Director (2005-2006)}

Indiana Mentor-Daleville, IN

Duties included, but were not limited to, management of supported living for mentally handicapped adults in 5 separate homes.

\section{Direct Service Employee (2000-2005)}

Indiana Mentor-Daleville, IN

Continuously administered over 6,500 hours of living assistance for mentally handicapped adults.

Provided professional support for 10-12 clients, in a variety of settings and through specialized programs, to live and work effectively within their home and community. Consistently worked to sustain a routine in each client's life that included appropriate behavior and positive life experiences. Personally and constructively interacted with clients on a daily basis. 


\section{Shift Manager (1997-2000)}

Kerasotes Theatres-Anderson, IN

Worked with, trained, and supervised all associates in every aspect of theatre operations.

\section{PROFESSIONAL ACTIVITIES}

\section{Conference Presentations}

Southern Forest Economics Workshop (SOFEW). March 20-22, 2011. Little Rock, Ark.

Presenter: An Evaluation of West Virginia's Non-Industrial Private Forest Landowner

Participation in Conservation Easements. Preliminary Analysis. ( 25 attendees)

\section{Guest Lectures}

Renewable Resource Policy and Governance (FOR 421). October 29, 2010. West Virginia University, Morgantown, WV.

Subject: Conservation Easements. Thirty-minute lecture defining and illustrating the structure of conservation easements, their usage, available programs and current issues. ( $\sim 50$ students)

\section{Meetings}

Association of the West Virginia Farmland Protection Boards Quarterly Meeting. April 19 ${ }^{\text {th }}, 2011$. Petersburg, WV. Affiliation meeting comprised of the United States Department of AgricultureNatural Resource Conservation Service ( USDA NRCS), the WV State Authority, the WV County Protection Boards and other contributing members. Discussed current issues related to conservation easements programs. $(3+\mathrm{hrs})$

Association of the West Virginia Farmland Protection Boards Quarterly Meeting. January $25^{\text {th }}, 2011$. Petersburg, WV. (4 hrs)

Conservation Easement Closing Meeting. December 15 $5^{\text {th }}$, 2010. Lewisburg, WV. Participated in a closing meeting for three conservation easements held by the USDA NRCS; which are located in Pocahontas County, WV. $(3+$ hrs $)$

Association of the West Virginia Farmland Protection Boards Quarterly Meeting. July $20^{\text {th }}, 2010$. Petersburg, WV. (3+ hrs)

\section{Workshops}

Easement Programs Workshop. February $15^{\text {th }}$, 2011. USDA NRCS. Morgantown, WV. Professional webinar/teleconference entitled: Implementing the Chief's Restoration Philosophy. Key topics included wetland and floodplain conservation easement programs. $(2+\mathrm{hrs})$

Community Design Team (CDT) field practicum. September 30-October 2, 2010. Montgomery, WV. Three day field research workshop to assist in producing a comprehensive plan for community development.

Forest Stewardship Property Tour. September $18^{\text {th }}$, 2010. Walnut Meadows Farm, Ruddle, WV. An immersive learning experience on land protected by a conservation easement. ( $4 \mathrm{hrs})$ 
Southern Forest Economics Workshop (SOFEW). March 15-18, 2010. Pinehurst, NC. Three day conference where forest economic and management research topics were presented and discussed.

\section{VOLUNTEER ACTIVITIES AND SERVICES}

Independent Study (FOR 595), USDA NRCS. Spring 2011. Morgantown, WV. Provided assistance with title reviews, programs files and other related activities for the USDA NRCS conservation easement programs. $(116+\mathrm{hrs})$

Earth Team Volunteer, USDA NRCS. Summer/Fall 2010. Morgantown, WV. Assisted Farm Bill Easement Program Specialist, Joe Hatton, in tasks related to conservation easement programs. $(89+\mathrm{hrs})$

Annual monitoring of a conservation easement. October $8^{\text {th }}, 2010$. Ruddle, WV. Participated in the yearly compliance inspection of an easement property conducted by Mike Powell, Land Steward for The Nature Conservancy. (5 hrs)

National 4-H Forestry Invitational. July $28^{\text {th }}$, 2010. Jackson's Mill, Weston, WV. Assisted with the academic quiz bowl and other forestry related activities. (12 hrs)

Annual monitoring of a conservation easement. June $19^{\text {th }}, 2010$. Morgantown, WV. Participated in the yearly compliance inspection of an easement property conducted by Matt Monroe, Independent Contractor. (3 hrs)

\section{RELEVANT COURSEWORK}

M.S.

Major: Forest Resources Management

Independent Study (See volunteer activities and services)

Renewable Resource Policy and Governance

Elements of Silviculture

Public Administration and Policy Development

Public Planning

\section{B.S.}

Major: Criminal Justice and Criminology

Current Topics (2 semesters)

Criminal Evidence

Crisis Intervention

Victimology

Organized Crime

Race and Gender

Juvenile Justice

Minor: Religious Studies

Research Methods

Paul and the Developing Church

New Testament

Old Testament
Statistical Methods 1

Categorical Data Analysis

Qualitative (Research) Methods

Vegetation of West Virginia

Data Analysis

Research Methods

Introduction to Courts

Introduction to Corrections

Introduction to Policing

Introduction to Criminology

Criminal Justice System

Religions of the World

Religion in America 


\section{REFERENCES}

Kathryn G. Arano, Ph.D.

Associate Professor of Forest Resources Management, Forest Economics

West Virginia University-Division of Forestry and Natural Resources

337D Percival Hall

PO Box 6125

Morgantown, WV 26506-6125

304-293-5321

kathryn.arano@mail.wvu.edu

John R. Brooks, Ph.D.

Professor of Forest Resources Management, Forest Biometrics

West Virginia University-Division of Forestry and Natural Resources

338A Percival Hall

PO Box 6125

Morgantown, WV 26506-6125

304-293-5313

john.brooks@mail.wvu.edu

Joe Hatton

Farm Bill Easement Program Specialist

United States Department of Agriculture, Natural Resources Conservation Service

West Virginia State Office

1550 Earl Core Rd, Suite 200

Morgantown, WV 269505

304-284-7564

joseph.hatton@wv.usda.gov

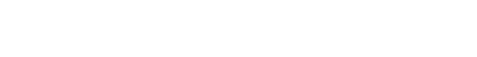

